\title{
The Effect of a Major Customer's Information Quality on Its Supplier's Investment Decisions
}

\author{
Dissertation
}

Presented in Partial Fulfillment of the Requirements for the Degree Doctor of Philosophy in the Graduate School of The Ohio State University

\author{
By \\ Aaron Nelson \\ The Ohio State University \\ 2018 \\ Dissertation Committee \\ Professor Andrew Van Buskirk, Advisor \\ Professor Zahn Bozanic \\ Professor Darren Roulstone \\ Professor Xue Wang
}

Graduate Program in Accounting and Management Information Systems 
Copyrighted by

Aaron S. Nelson

2018 


\begin{abstract}
In this study, I examine the role that a major customer's information quality plays in a supplier's investment decisions. I propose that the flow of high-quality information from a customer to its suppliers reduces a supplier's uncertainty and increases supplier investment. Using variation in the customer's disclosures as proxies for information quality, I find evidence that suppliers face less uncertainty, have higher investment levels, and are less responsive to observed uncertainty when their customers have higher quality information. The effect on suppliers appears to be driven by the customers' demand related information, as customer sales guidance is related to supplier investment, but earnings guidance is not. I use restatements as an additional proxy for customer information quality and continue to find reduced sensitivity to uncertainty. These results build on the literature in accounting that investigates information spillovers from one firm to another and provide evidence that customers are a source of information that can mitigate the negative effects of uncertainty.
\end{abstract}




\section{Dedication}

I dedicate this work to my loving wife, Jenny, who has supported me throughout the entire process. Thank you for taking care of my needs and bringing our three children into this world during the course of my program. Nadya, Simon, and Krycia, The ability to come home to your smiling faces has meant more to me than you will ever know. 


\section{Acknowledgments}

I am indebted to my advisor, Andy Van Buskirk, for providing continuous guidance and support throughout the dissertation writing process. I am also grateful to my dissertation committee members, Darren Roulstone, Zahn Bozanic, and Xue Wang, who have provided a great deal of personal and professional support to me.

I received helpful comments and suggestions from Hailey Ballew, Brent Schmidt, Anne Beatty, Min Park, Eric Holzman, Anil Arya, Doug Lambert, Pablo Machado, Richard Dietrich, and workshop participants at The Ohio State University and McMaster University. I thank Joshua Madsen and Nathan Marshall for providing insight into the data that I use in this project. I acknowledge the Fisher College of Business, the KPMG Foundation, and the American Indian Graduate Council for financial support. 


\section{Vita}

2012

Bachelor of Science, Accounting, Utah Valley

University

2013

Master of Accountancy University of Utah

2013 - Present

Graduate Research and Teaching Associate,

Department of Accounting and MIS, The Ohio State

University

Fields of Study

Major Field: Accounting and Management Information Systems

Minor Field: Economics and Statistics 


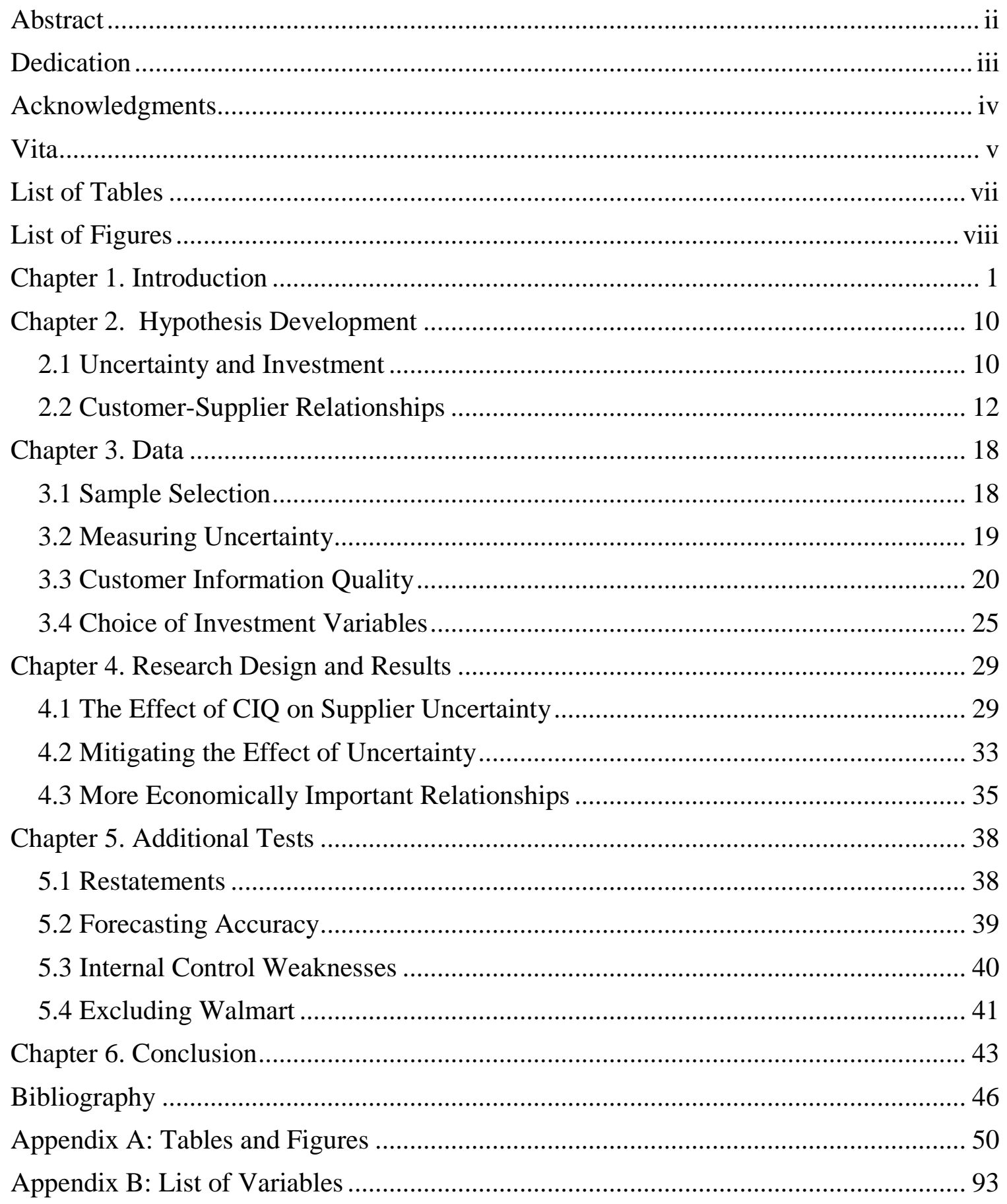




\section{List of Tables}

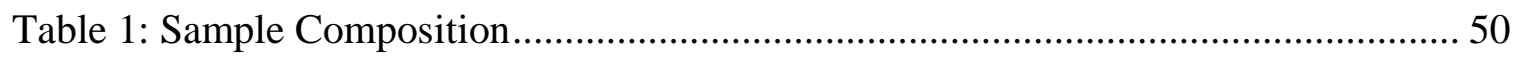

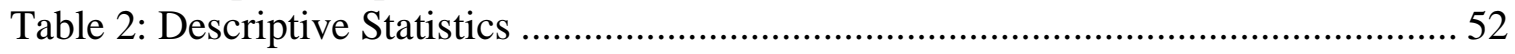

Table 3: The Relationship Between Investment and a Firm's Expected Volatility......... 56

Table 4: The Relationship Between CIQ, Uncertainty, and Investment........................ 59

Table 5: The Effect of Customer Information Quality on the Volatility-Investment

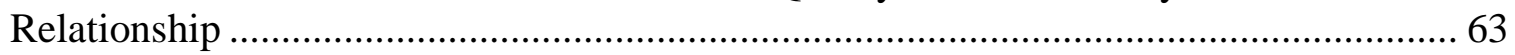

Table 6: Cross-Sectional Tests with More Important Relationships .............................. 65

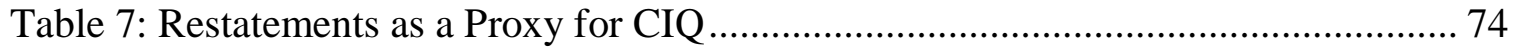

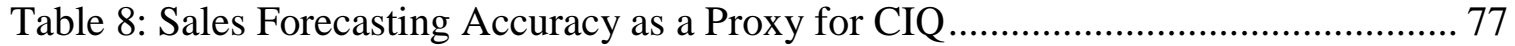

Table 9: Earnings Forecasting Accuracy as a Proxy for CIQ ........................................ 80

Table 10: Internal Control Weaknesses as a Proxy for CIQ ....................................... 83

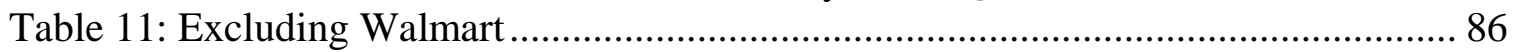




\section{List of Figures}

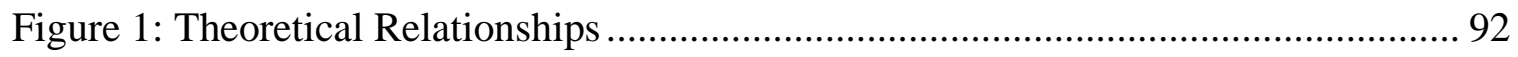




\section{Chapter 1. Introduction}

In this study, I investigate whether a major customer's information quality affects investment decisions made by its supplier. ${ }^{1}$ Businesses operate in an uncertain environment and make investment decisions without perfect foresight of the outcome. A rich literature in economics examines how uncertainty affects management investment decisions (Dixit and Pindyck 1994; McDonald and Siegel 1986). This literature generally finds that managers are more likely to pass on investment opportunities that have a positive expected value when there is more uncertainty about the outcome, reducing overall investment. High-quality information reduces the uncertainty about potential investment projects. With less uncertainty managers take on more projects that have a positive expected value and increase overall investment. I propose that high-quality customer information reduces a supplier's uncertainty and increases its overall investment.

Managers evaluate investment decisions based on the information that is available to them at the time of investment. Because the end result of investment is not perfectly predictable, managers consider the possible outcomes from investment based on available information as well as the option to wait for better information before making a final investment decision. Theoretical research has modeled this problem and shown that the

\footnotetext{
${ }^{1}$ I rely on suppliers' ASC 280 disclosures that define major customers as those customers accounting for $10 \%$ or more of the entity's revenue.
} 
option value of waiting increases with the spread of potential returns on investment, which causes firms to invest less than they would with more precise information (McDonald and Siegel 1986; Dixit and Pindyck 1994; Abel 1983; Caballero 1991). The empirical literature has generally confirmed the predicted negative relationship between uncertainty and investment (Leahy and Whited 1996; L. T. Bulan 2005; Arif, Marshall, and Yohn 2016; Eisdorfer 2008). For example, recent literature in accounting has explored how political connections can serve as a source of information that mitigates the impact of political uncertainty on investment (Wellman 2017).

I focus on firms' major customers as another potential source of information that could affect firms' willingness to invest. The customer-supplier relationship offers a useful setting to examine investment-related information flows for a few reasons. First, information about future demand is an important factor in nearly all investment decisions. Customers have superior understanding and access to recent information about the end consumer compared to suppliers and make more accurate predictions about upcoming changes in demand (Lee, Padmanabhan, and Whang 1997). Second, customers and suppliers share a substantial amount of information. At a minimum, the supplier has information about the customer's orders, but it is common for suppliers to access customer inventory information and have regular contact with the customer's relevant managers. The customer's management can share information related to shifts in demand, changes in the 
customer's strategy, and other information that is relevant to the supplier's business. The supplier's reaction to shared information depends on the quality of that information. ${ }^{2}$

Because direct communication between a customer and supplier is inherently unobservable, I use customers' voluntary disclosures as proxies for the quality of information they share with their suppliers. Prior literature links the quality of publicly disclosed information to the quality of internal information that the firm uses for investment decisions (Hemmer and Labro 2008; McNichols and Stubben 2008; Goodman et al. 2014; Trueman 1986; Verrecchia 1990). Intuitively, if a firm has high-quality information regarding future changes in demand, costs, or operations, then it is likely to use that information to make forecasts about future outcomes. If customers have high-quality internal information they can share better information with their suppliers than customers with lower quality information.

My first proxy for customer information quality (CIQ) is an indicator variable for whether or not the customer issues a sales forecast. ${ }^{3}$ Verrecchia (1990) predicts that a manager is more likely to disclose private information when that information is more precise. If the customer's revenue forecast is indicative of high-quality information about demand, then customers that issue revenue forecasts have better demand information to share with their suppliers. My second proxy for CIQ is an indicator variable for whether the customer issues an earnings forecast. Earnings forecasts are more common, represent

\footnotetext{
${ }^{2}$ In general, the quality of information in a particular context reflects both the precision of the information and the relevance of that information for decision-making purposes.

${ }^{3}$ By focusing on a particular type of information that should be directly relevant to suppliers' investment decisions (i.e., customer information about end-user demand), I hold constant the relevance of customers' information and focus on the precision of that information.
} 
information quality beyond demand, and are specifically linked to higher quality internal information (Trueman 1986, Ittner and Michels 2017).

My second construct of interest is the supplier's uncertainty. I use the supplier's expected stock return volatility as a proxy for the supplier's uncertainty (Eisdorfer 2008; Arif, Marshall, and Yohn 2016). The supplier's volatility captures information that investors deem relevant to future cash flows and approximates the uncertainty that a manager faces when making an investment decision (Leahy and Whitehead 1996). Lastly, I proxy for the supplier's investment using changes in working capital ${ }^{4}$ (Fairfield, Whisenant, and Yohn 2003; Arif, Marshall, and Yohn 2016).

Although my proxies for customer information quality are publicly observable, the information shared by suppliers can be either public (e.g., a publicly-issued revenue forecast) or private (e.g., confidential revenue targets or end-user orders). To account for both possibilities, I examine the relation between customer information quality and supplier investment decisions in two ways. ${ }^{5}$ The first approach accounts for situations where the shared information is largely publicly observable and incorporated into stock prices (i.e., observed volatility is a reasonable proxy for the supplier's uncertainty), and has three testable predictions. First, I should observe a negative relation between the customer's information quality and the supplier's expected volatility. Second, I should observe a positive relationship between the customer's information quality and the

\footnotetext{
${ }^{4}$ Prior research has used capital expenditures to examine the relation between uncertainty and investment. I discuss the rationale for using working capital changes rather than capital expenditures in chapter 3.7.

${ }^{5}$ While the predictions are distinct, they are not mutually exclusive. It is likely that the supplier's expected volatility incorporates only a portion of the customer's information quality because the customer's public disclosures only contain a portion of the information that they share with suppliers.
} 
supplier's investment in working capital because reduced uncertainty is associated with higher levels of investment. Third, the positive relationship between a customer's information quality and the supplier's investment in working capital should be mediated by the supplier's expected volatility.

The second approach accounts for the possibility that the shared information is private, so that observed stock volatility does not incorporate the shared information that affects the supplier's uncertainty. The set of predictions under this approach falls in line with prior research that examines how an information source mitigates the effect of observed uncertainty when that measured uncertainty is unaffected by the information source in question. If expected volatility does not reflect private information, but the supplier manager still accounts for the information when making investment decisions, then I should observe an attenuated relationship between the supplier's expected volatility and the supplier's investment levels when customer information quality is higher (Czarnitzki and Toole 2011; Wellman 2017).

I use suppliers' publicly disclosed major customers to identify public customersupplier pairs from 2001-2016. I require that customers are covered by I/B/E/S to ensure that I capture their sales and earnings guidance. This sample selection procedure leads to the suppliers in the sample being substantially smaller than their major customers. This size differential likely results in supplier firms that operate in poorer information environments, with the potential to benefit from the information production of their larger counterparts. 
The empirical results indicate that when customers issue sales forecasts their suppliers experience lower expected volatility, consistent with higher CIQ reducing supplier uncertainty. However, there is no detectable difference in the supplier's expected volatility when customers issue an earnings forecast. Similarly, customer revenue forecasts are associated with higher levels of supplier investment, but that association does not hold for earnings forecasts. Path analysis indicates that there is a significantly positive indirect effect of customer disclosure on supplier investment levels. The tests indicate a larger effect of customer sales forecasts than customer earnings forecasts in all tests. Overall, these results provide evidence that high-quality customer information has a positive effect on a supplier's investment levels because it reduces the supplier's uncertainty. The relatively greater effect of sales forecasts is consistent with high-quality demand information being particularly important to the suppliers.

My second set of tests examines whether the customer's information mitigates the effect of observed uncertainty on supplier investment levels. The relationship between a supplier's investment in working capital and expected volatility is attenuated when a customer issues sales forecasts. However, this is not the case when a customer issues an earnings forecast. These results indicate that observed uncertainty has a weaker effect on investment levels when the supplier has access to high-quality demand information. Taken together, the set of tests is consistent with demand information having a positive effect on supplier investment levels by reducing the supplier's uncertainty.

In addition to the above tests, I use alternative measures for CIQ to assess the robustness of my results. Prior research finds that the accuracy of a firm's forecasts, and 
not just the choice to forecast, is linked to the firm's information quality (Goodman et al. 2013, Ittner and Michels 2017). I follow this research and examine whether a supplier's uncertainty and investment vary with the accuracy of its customer's sales and earnings forecasts. Revenue forecasting accuracy is negatively related to the supplier's uncertainty, but other results no longer hold using accuracy as a proxy for CIQ. The results may not hold because the subsample of forecasting firms has consistently high information quality, so that variation in accuracy within those firms is less important.

I also use a customer's lack of Internal Control Weaknesses and restatements as proxies for CIQ. I do not find evidence that either proxy is associated with lower observed uncertainty, but I do find that they are both associated with suppliers having an attenuated investment response to observed uncertainty, consistent with the customer's information quality affecting only the supplier's private information, but not the observed volatility. Finally, Walmart accounts for a significant proportion of the customer observations in my sample. To ensure that the results are not driven by a particular dynamic of Walmart's relationship with its suppliers, I exclude Walmart from the sample and demonstrate that my primary results continue to hold.

These results contribute to several lines of research. First, I add to the literature on the effect of uncertainty on investment. These studies generally show a negative relationship between investment and uncertainty and several focus on an economic force or incentive that mitigates the response to uncertainty ${ }^{6}$. Within the accounting literature,

\footnotetext{
${ }^{6}$ Examples include compensation schemes, financial distress, patent protection, and political institutions (Panousi and Papanikolau 2012, Eisdorfer 2008, Czarnitzki and Tooele 2011, Julio and Yook 2012)
} 
Wellman (2017) examines political connections as a source of information that reduces the uncertainty over returns from investments that comes from political uncertainty. While Wellman (2017) demonstrates that access to information mitigates the effect of uncertainty, I find evidence that information quality not only lowers suppliers' investment sensitivity to observable uncertainty, but also reduces observable uncertainty. Both of these effects imply that improved information systems may lead to more real investment.

I also contribute to the line of literature that examines the spillover effects of information quality (Beatty, Liao, and Yu 2013; Chen, Young, and Zhuang 2013; Zhang and Zhang 2016; Badertscher, Shroff, and White 2013). A substantial portion of this literature focuses on spillover of information among industry peers and the effect of publicly disclosed information. The papers that examine the effect of a customer's information on the supplier generally focus on how the information is processed by a third party (Madsen 2017; Dhaliwal, Shenoy, and Williams 2016; Files and Gurun 2017). I add to these studies by focusing on the direct effect of customer information on a supplier's decisions and providing evidence that higher customer information quality increases supplier investment levels.

Finally, I contribute to the literature on the link between disclosure choices and the quality of a firm's internal information (Trueman 1986; Verrecchia 1990; Goodman et al. 2013; Ittner and Michels 2017). These prior studies have either theoretically demonstrated a link between disclosure and information quality, associated outcomes from internal decision-making processes with disclosures, or associated disclosure quality with data about a firm's internal systems. In contrast, I examine a setting that is known to have 
substantial private information flow and provide evidence that the quality of shared information is associated with disclosure choices.

The next Chapter reviews relevant literature and develops my hypotheses. Chapter 3 describes the data and empirical implementation of the constructs. Chapter 4 provides the research design and discusses the results. Chapter 5 provides additional tests and Chapter 6 concludes. 


\section{Chapter 2. Hypothesis Development}

\subsection{Uncertainty and Investment}

A line of literature in economics has long investigated the effect of uncertainty on investment (Hartman 1972; Bernanke 1983; Abel 1983; Abel and Eberly 1994; Dixit and Pindyck 1994) ${ }^{7}$. This literature predicts a negative relationship between uncertainty and investment under certain conditions. If an investment opportunity has some degree of irreversibility, uncertainty, and the manager has leeway over the timing of investment, then the option to wait is valuable and that value increases in the uncertainty of returns on investment (Dixit and Pindyck 1994). A manager will choose to exercise the option to wait so long as the expected value of immediate investment does not exceed the value of the option. As the value of the option increases in uncertainty, the manager will pass on more projects if uncertainty is high, reducing overall investment.

Leahy and Whited (1996) demonstrate that a negative relationship between uncertainty and investment exists by examining the relationship between a firm's stock price volatility and capital expenditures in a set of manufacturing firms. A number of other

\footnotetext{
${ }^{7}$ The theoretical literature identifies several mechanisms that can affect this relationship, including risk aversion, opportunity costs, the value of waiting for better information, cost to adjustment, irreversibility, risk preferences, and others. While a mixture of these different aspects can lead to ambiguous predictions about the relationship between investment and uncertainty, the majority of the empirical literature finds a negative relationship between the two (Julio and Yook 2012; Baker, Bloom, and Davis 2016; Nguyen and Phan 2017; Jens 2017).
} 
studies examine volatility and investment and continue to observe the negative relation (Ogawa and Suzuki 2000; Bulan 2005; Eisdorfer 2008; L. Bulan, Mayer, and Somerville 2009; Arif, Marshall, and Yohn 2016).

Panousi and Papanikolaou (2012) examine managerial risk aversion as a contributing factor to the relationship between investment and uncertainty and examine factors that can mitigate the effect of uncertainty. They find a negative relationship between uncertainty and idiosyncratic volatility and that this relationship varies with the ownership stake that the manager has in the firm. They further find that this effect is weaker when an owner has more option-based compensation and when the firm has high institutional ownership, suggesting that the relationship between uncertainty and investment partially operates through managerial risk aversion.

Other studies have examined mechanisms that mitigate the negative effect of uncertainty. Czarnitzki and Toole $(2007,2011)$ find that patent protection can help spur more innovation by reducing the effect of uncertainty on investment. Czarnitzki and Toole (2007) find that government R\&D subsidies reduce the negative effect of product market uncertainty on investment, while Czarnitzki and Toole (2011) find that firms with more existing patents are less affected by the volatility of new products that they introduce. Julio and Yook (2012) investigate the effect of uncertainty from political elections on firm level investment across 50 countries. They find that upcoming elections reduce investment across the full sample, but that countries with common-law systems, more stable governments, governments that play a smaller role in the economy, and governments with 
a system of checks and balances have a smaller decrease in investment prior to political elections.

Within the recent accounting literature, Wellman (2017) investigates how information can alter the effect of political uncertainty on investment. She builds on the literature that finds a negative relationship between political uncertainty and investment and tests whether access to political information improves a managers information set, causing a relatively weaker relationship between observed political uncertainty and investment (Julio and Yook 2012; Baker, Bloom, and Davis 2016). She finds that firms that make more political contributions have weaker investment response to political uncertainty, suggesting that managers of these firms perceive lower spreads in their firms' potential returns due to general political uncertainty. Similarly, I investigate information flow from a major customer and test whether the customer's information quality affects the uncertainty at the supplier and alters investment levels.

\subsection{Customer-Supplier Relationships}

The link between customers and suppliers offers a promising setting to examine external information affecting a firm's uncertainty. First of all, customers are generally better informed about downstream demand for the final product than their suppliers. Customers tend to have closer relationships with the final consumer and are better informed about upcoming production schedules and other factors relevant to the supplier's business (Lee and Whang 2000). Additionally, we know that there is significant information flow 
along the supply chain, making it likely that relevant private information at a customer is being passed on to the supplier (Andon, Baxter, and Chua 2015).

The majority of studies that assess the value of a customer's information to a supplier investigate how public information about the customer affects assessments of the supplier by a third party. For example, Olsen and Dietrich (1985) study the effect of a customer's information on the supplier's shareholders. Their study documents that major retailers' sales information affects security returns at their suppliers, while Cohen and Frazzini (2008) find that a customer's earnings predict the supplier's future returns. Files and Gurun (2017) find that lenders require a higher interest rate from suppliers after a major customer has had a restatement and that the effect on interest rates is more pronounced when a supplier has higher switching costs. Finally, both auditors and analysts produce higher quality outputs for the supplier when they work with major customers as well (Guan, Wong, and Zhang 2015; Luo and Nagarajan 2015; Johnstone, Li, and Luo 2014; Dhaliwal, Shenoy, and Williams 2016). These studies suggest that understanding how a customer firm affects a supplier is beneficial for third parties, even those with access to private information.

A few studies examine how customer information affects the supplier itself. Raman and Shahrur (2008) predict that customers will manipulate publicly available information to induce relationship-specific investment by their suppliers. Their study finds that when industries require more relationship-specific investment they tend to have higher levels of absolute discretionary accruals and that customers manipulate earnings to induce 
investment by suppliers. This indicates that suppliers do use publicly observable information from their customers to make investment decisions.

Additionally, some studies indicate that customers and suppliers share a substantial amount of non-public information. Costello (2013) describes contracts between customersupplier pairs. She finds that contracts include covenants to share financial information as well as rights to visit the other party's facilities. Additionally, Cen et al. (2017) find that both customers and suppliers benefit from tax structures that they set up to shift profits to low-tax jurisdictions. Tax planning requires information exchange well beyond what is publicly visible, suggesting a substantial amount of coordination between the parties.

Bauer, Henderson, and Lynch (2017) examine internal control weaknesses at both customers and suppliers and find that they negatively impact the length of the customersupplier relationship. The effect is strongest for weaknesses related to inventory, revenue, and intercompany transactions, suggesting that the quality of information that is passed along the supply chain is important to maintaining relationships. Overall, the research indicates that there is substantial information sharing in customer-supplier relationships, that suppliers invest more when their customers manage earnings upwards, and that the customer-supplier relationship is more likely to continue if both parties have higher quality information.

I add to the literature on customer-supplier interactions by examining the effect of a customer's information quality (CIQ) on the supplier's investment levels ${ }^{8}$. A customer

\footnotetext{
${ }^{8} \mathrm{I}$ am interested in the quality of information that the customer shares with its suppliers; however, I am unable to observe communication between the customer and supplier and only refer to information quality throughout the paper. Customer forecasting behavior captures not only the quality of information, but also a willingness to share the information, suggesting that it is a valid proxy for the underlying construct.
} 
with high-quality information can share that information with its suppliers and the supplier should take that information into account when making investment decisions. Information that is both relevant and reliable should reduce the perceived distribution of possible outcomes from investment, reducing the supplier's uncertainty. The literature on investment under uncertainty suggests that reduced uncertainty leads to higher investment levels. While the theoretical link between these constructs is clear and displayed in figure 1, the detectable empirical relationship depends on measurement of the supplier's uncertainty and the effect of CIQ on the uncertainty measure. To measure management uncertainty, I use the supplier's expected stock return volatility. It is unclear whether the customer's information quality is impounded into the supplier's stock returns, thus I make separate predictions based on whether or not the supplier's expected volatility captures the effect of CIQ.

My first set of hypotheses assumes that the customer's shared information quality is at least partially publicly observable, so that the observed uncertainty measure will incorporate the information influencing the supplier's investment decisions. If this is true, I should first observe a negative relationship between CIQ and the supplier's uncertainty. Second, the reduced uncertainty should lead to higher investment levels, implying a positive relationship between CIQ and the supplier's investment. Finally, If the positive relationship between CIQ and the supplier's investment is due to the effect of CIQ on supplier uncertainty then it should be mediated by the supplier's uncertainty. I state these predictions more formally in my first set of hypotheses (stated in alternative form): 
H1a: Suppliers face less uncertainty when their customers have high-quality information. H1b: Suppliers have higher investment levels when their customers have high-quality information.

H1c: Supplier uncertainty mediates the relationship between high-quality customer information and supplier investment levels.

My second set of hypotheses allows communication between customers and suppliers to remain completely private and have no effect on the supplier's expected volatility. If expected volatility does not capture private information then it is not the uncertainty in the supplier's uncertainty, but rather the uncertainty of outsiders without access to the private information. If the supplier updates its beliefs based on private customer information then the gap between observed uncertainty and the supplier's actual uncertainty grows. As this gap widens, the observable relationship between uncertainty and investment is attenuated. Stated formally:

H2: The negative effect of observed uncertainty on investment is mitigated by highquality customer information.

My third set of predictions relies on the idea that when a customer is more important to a supplier, information coming from the customer should be more relevant to the supplier. Pandit et al. (2011) find that the market reaction of a supplier's stock to the customer's earnings announcement increases in the percentage of sales that go to the 
customer. Thus, the demand information coming from a customer is more relevant to the supplier's investment decisions if the supplier has a higher percentage of sales going to that customer. Therefore, I expect that the effect of CIQ will be stronger when the customer is relatively more important to the supplier, based on the percentage of sales that go to that customer. I test the following set of hypotheses:

H3a: The relationship between supplier uncertainty and high-quality customer information is stronger when the customer accounts for a larger portion of the supplier's sales.

H3b: The relationship between supplier investment and high-quality customer information is stronger when the customer accounts for a larger portion of the supplier's sales.

H3c: The mediating effect of supplier uncertainty on the relationship between highquality customer information and supplier investment levels is stronger when the customer accounts for a larger portion of the supplier's sales.

H4: The mitigating effect of high-quality customer information on the investmentuncertainty relationship is stronger when the customer accounts for a larger portion of the supplier's sales. 


\section{Chapter 3. Data}

\subsection{Sample Selection}

I begin my sample selection with the intersection of Compustat and CRSP from 2001 through 2016. I find 41,930 firm-years that have the necessary data to examine the relationship between expected volatility and investment after dropping utility and financial firms. I rely on Accounting Standards Codification (ASC) 280 to identify customersupplier links. ASC 280 requires firms to disclose major customers that make up at least $10 \%$ of total sales for the firm. The Compustat Segment Files provide the names of customers. I match the customer names to the Compustat Header File using a phonetic string matching algorithm and manually verify all matches. I then take customers that do not link to a public firm and rerun the algorithm with looser parameters and manually examine suggested matches to avoid missing potential customer-supplier links ${ }^{9}$. I identify 8,818 supplier-customer-years that have sufficient data to estimate the relationship between investment and uncertainty. Requiring additional customer control variables reduces the sample to 8,765 observations. This is the primary sample that I use throughout the paper. It consists of 2,500 customer-supplier pairs coming from 1,406 unique suppliers

\footnotetext{
${ }^{9}$ This creates over 60,000 potential links between disclosed names and public firms. I am intentionally conservative in matching to avoid false customer-supplier links. I use google search and SEC filings to verify matches. I thank Josh Madsen for sharing insight into this process.
} 
and 513 unique customers ${ }^{10}$. Finally, tests that use the accuracy of a customer's guidance to proxy for information quality require the customer to provide earnings or revenue guidance. These samples contain 6,056 observations and 3,380 observations for earnings and sales guidance respectively.

Table 1 provides some details on the sample composition. Panel A shows the industry distribution of suppliers, $71 \%$ of supplier firms are from the manufacturing sector compared to 51\% from the general Compustat population. Panel B shows the 10 most common customers in the sample. Walmart is the most common customer, accounting for $13 \%$ of the observations in my sample ${ }^{11}$. Other large companies make up the remainder of the top 10.

\subsection{Measuring Uncertainty}

Ideally, the empirical measure of uncertainty should capture the variance of potential returns that a manager expects from investment opportunities, and particularly the variance of cash flows that may be informed by a customer's information. I follow prior research and use the supplier's expected stock return volatility as a proxy for the uncertainty that the manager faces. Specifically, I use a generalized autoregressive conditional heteroskedasticity $(\mathrm{GARCH})(1,1)$ model to transform the series of stock returns into an expected measure of volatility (Eisdorfer 2008; Arif, Marshall, and Yohn 2016). The

\footnotetext{
${ }^{10}$ Accounting Standard Codification 280 requires firms to disclose customers that make up at least $10 \%$ of total revenue. This leads to a sample that has unique supplier-customer-years. Some suppliers disclose multiple customers during the same year and several large customers have multiple suppliers report them as a principle customer. Results are robust to limiting the sample to the largest reported customer.

${ }^{11}$ In Chapter 5.5 I include a robustness check that excludes Walmart with no significant change to the main results.
} 
GARCH model estimates the volatility of returns in year $t+1$ conditional on returns up until the end of year $t$. More recent returns are given greater weight in the model and large volatility shocks persist for longer periods compared to historical volatility. Consistent with Arif et al. (2016) I use the series of firm returns up until the last trading day of year $t$. I require at least 200 daily return observations for the firm to be included in the sample. While this measure of expected volatility does not specifically incorporate market participants' expectations of future uncertainty (as opposed to option-based implied volatility or analyst dispersion), it only requires a relatively short series of market prices and does not impose major restrictions on my sample ${ }^{12}$.

\subsection{Customer Information Quality}

I am interested in capturing the supplier's updated beliefs based on the information that it receives from the customer. I assume that customers with high-quality information share better information with their suppliers and reduce the supplier's uncertainty more than customer with low-quality information. Researchers have developed a number of ways to measure the quality of a firm's externally reported information, but the information shared with suppliers is not necessarily publicly available. I rely on the literature that links the quality of a firm's voluntarily disclosed information to the quality of its internal information to capture the quality of information shared with suppliers (Hemmer and Labro

\footnotetext{
${ }^{12}$ Other potential measure of uncertainty include analyst dispersion (Barron and Stuerke 1998) and implied volatility (Bozanic et al. 2018). These measures require multiple analysts following the firm and publicly traded options, respectively, both of which substantially reduce my sample size because the supplier firms in my sample tend to be smaller firms with relatively low analyst following and without traded options.
} 
2008; Goodman et al. 2014; Ittner and Michels 2017; Gallemore and Labro 2015; Verrecchia 1990; Trueman 1986).

The theoretical literature linking voluntary disclosure to a firm's information quality shows that the probability of disclosure increases as the precision of private information increases (Verrecchia 1990). Therefore, I use indicator variables for whether or not the customer issues guidance to proxy for the customer's information quality. I use indicators for both sales $(R E V)$ and earnings guidance $(M F)$ as proxies. Customers that issue sales guidance should have better information about future demand. Such highquality information about a customer's future demand should be useful to suppliers, as their demand is directly tied to the customer's demand for their inputs. I also use an indicator for earnings guidance. Earnings forecasts are more common and should be indicative of information quality beyond just demand information. Using earnings forecasts allows for a broader set of customers to be considered as having high-quality information and the differential impact of earnings vs. sales forecasts should be informative about the importance of demand information to the supplier.

In robustness tests, I follow empirical literature that links the accuracy of a firm's forecasts, rather than the decision to issue a forecast, to the quality of that firm's internal information. Ittner and Michels (2017) verify that firms with better internal information tend to forecast more accurately by examining the relationship between the accuracy of a firm's earnings guidance and the use of risk-based forecasting for internal purposes, while Goodman et al. (2014) find that firms with more accurate forecasts make better investment decisions. I adapt a measure of management guidance accuracy from Goodman et al. 
(2014) as an additional proxy of the customer's information quality. Rev_Accuracy (Earn_Accuracy) is the average forecast accuracy for all annual sales (earnings) forecasts issued by the customer over the three years before the investment period. I use the absolute value of forecast errors to assess accuracy and multiply the final measure by -1 so the resulting coefficient can be interpreted as the effect of accuracy. I.e. for a supplier's investment in year $\mathrm{t}+1$ I use the customer's forecasts issued during the supplier's fiscal years $t, t-1$, and $t-2$. Forecast accuracy is measured as the absolute value of the point estimate, or midpoint of range estimates, less the actual earnings from $\mathrm{I} / \mathrm{B} / \mathrm{E} / \mathrm{S}$ scaled by the stock price three days prior to the forecast date. Additionally, I exclude forecasts that are made less than three weeks prior to the annual earnings announcement to avoid including earnings pre-announcements.

One potential concern in my setting is the endogenous nature of management forecasts. Customers are more likely to provide forecasts when operating in a steady and predictable environment, while suppliers are less likely to be affected by uncertainty when they have a steady and reliable customer that accounts for a significant portion of their sales. I am interested in the effect of information that customers share with their suppliers, not the way that economic stability affects investment. Therefore, the driving factors of forecasting behavior and accuracy are correlated variables that must be controlled for to examine the effect of internal information passing from customer to supplier.

Fortunately, analysts provide a natural control for the factors that influence the customer's forecast decisions and guidance properties. Analysts' forecasts should reflect 
external information that affects the customer's guidance ${ }^{13}$. I include Cust_Analyst_Accuracy as the average accuracy of the analyst's annual forecasts measured over the same time period as the customer's guidance. One issue with controlling for analyst accuracy in this setting is that analysts have close contact with management and their forecasts likely reflect the quality of internal information at the firms for which they forecast. If managers' forecasts lead analysts to issue more accurate earnings estimates, then controlling for the accuracy of those earnings estimates will inappropriately bias against finding an effect of customer information quality on supplier investment. Therefore, the estimated effect of a manager's forecasting properties is likely to be a lower bound on the true effect when controlling for the analysts' forecasting accuracy ${ }^{14}$.

Because I want to capture the customer's ability to generate and share reliable information, and not the predictability of the customer's economics, I control for other factors that influence guidance properties. I include the standard deviation of the customer's quarterly earnings (Cust_STD_ROA) from year $t$-2 through year $t$ as another proxy for the customer's predictability. In tests that use Rev_Accuracy and Earn_Accuracy, I also include Cust_Horizon, the average of the log of the number of days between the date of the customer's guidance and the date of the earnings announcement, because forecasts made earlier in the period are less accurate on average Finally, I control for the log of the

\footnotetext{
${ }^{13}$ In fact, analysts are more likely to understand macroeconomic and industry information than managers (Hutton, Lee, and Shu 2012).

${ }^{14}$ In untabulated tests I exclude the analysts' accuracy from tests. Consistent with the analysts' accuracy over controlling for determinants of the management forecast accuracy, the coefficients on CIQ are larger when excluding the analysts' accuracy. However, this does not alter the statistical significance of most tests.
} 
customer's market value of equity (Cust_Size) to capture other features of the customer's information environment.

Table 2 panel A shows descriptive statistics for the primary sample. I find that customers are significantly larger than suppliers with a mean market capitalization of about $\$ 75$ Billion, compared to $\$ 3.9$ Billion for suppliers. This is consistent with prior research (Bauer, Henderson, and Lynch 2017), the disclosure requirements in ASC 280, and the most common customers in the sample being large firms. This size disparity makes it likely that the customers will have more resources to conduct market research and invest in other information gathering processes than the suppliers. Measures of expected volatility are similar to those reported in Arif et al. (2016). Panel B displays differences between observations with a customer issuing a sales forecast and those without. Consistent with my set of predictions in $\mathrm{H} 1$, suppliers have higher investment in working capital and lower volatility when their customers issue sales forecasts; however, capital expenditures are lower. Suppliers with non-forecasting customers also have more cash flows from operations, which would generally increase investment and work against my ability to provide support for $\mathrm{H} 1 \mathrm{~b}$.

Panel C provides means for subsamples where a customer issues a sales forecast, an earnings forecast, both, or neither. The highest working capital investment and near lowest expected volatility is found when customers disclose both earnings and sales forecasts. The accuracy of customers' earnings guidance, Earn_accuracy, is about -0.007 compared to -0.024 reported in Goodman et al. (2014). Panel D shows the accuracy of all firms that issue an earnings forecast during my sample period with the same selection 
procedure, except they are not required to be reported as a major customer. Again, the customers in my sample are more accurate forecasters than the general population, indicating a set of customers with higher than average information quality. Finally, the univariate correlations in panel $\mathrm{E}$ show that customer revenue forecasts are positively correlated with supplier investment in working capital and all CIQ proxies are negatively related to the supplier's expected volatility. These provide initial evidence for my first hypothesis.

\subsection{Choice of Investment Variables}

I begin by investigating the relation between investment and uncertainty within my sample. Although prior research has generally found a negative relationship between uncertainty and investment, understanding the relationship within my sample will inform my conclusions about the effect of CIQ. I replicate the following model from Arif et al. (2016) to establish the baseline relation between volatility and investment within my sample and for comparison to prior literature.

$$
\begin{aligned}
& \text { Investment }_{i t+1}=\beta_{1} \text { Expected_Volatility }_{i t}+\beta_{2} \text { Size }_{i t}+\beta_{3} \text { MTB }_{i t}+\beta_{4} \text { Leverage }_{i t}+ \\
& \beta_{5} \text { CFO }_{i t}+\beta_{6} \text { Capital_Intensity }_{i t}+\beta_{7} \text { Recession }_{i t+1}+\beta_{8} \text { Default_Spread }_{i t+1}+ \\
& \beta_{9} \text { Interest_Rate }_{i t+1}+\epsilon_{i t}
\end{aligned}
$$

I investigate three potential proxies for investment. First, capital expenditures (Capex) represent the long-term capital investments that the supplier makes in year $t+1$. Next, I 
adopt the perspective that working capital accruals represent an intentional investment made by the firm (Fairfield, Whisenant, and Yohn 2003; X. F. Zhang 2007). Arif et al. (2016) demonstrate that working capital accruals are negatively related to a firm's expected volatility and that the asset portion of working capital accruals has the strongest relation. Hence, I use both net working capital accruals, $W C$, and the asset portion of working capital accruals, WC_Assets, as proxies for investment and examine their relation to uncertainty within my sample.

I control for other common determinants of a firm's investment levels (Eisdorfer 2008; Arif, Marshall, Yohn 2016). Size is the natural $\log$ of the firm's market value of equity. MTB is the ratio of a firm's market value to book value and is meant to capture growth opportunities. Leverage and $C F O$ capture availability of capital for investment. Capital Intensity is measured as the ratio of net property, plant, and equipment to total assets and controls for the supplier's reliance on capital equipment. I control for other macroeconomic factors by including Recession, an indicator for whether period $t+1$ is defined as a recession period by the NBER because investment is lower during times of recession; Default_Spread, the yield spread between Aaa and Baa rated bonds; and Interest_Rate, the nominal rate on a 1 year T-Bill. For comparability with prior results, and to allow cross-sectional differences in volatility to capture the firm's uncertainty, I do not include fixed effects (Eisdorfer 2008; Arif. et al. 2016). All variable definitions can be found in Appendix A.

Table 3 panel A presents the result from estimating equation (1) within my sample of customers and suppliers. The results indicate that the expected negative relationship 
between capital expenditures and expected volatility does not exist within my sample. However, the relation between investment in working capital and volatility is negative and significant within my sample and that relation is stronger for the asset portion of working capital.

The lack of relationship between capital expenditures and expected volatility is unexpected, as I closely follow prior research that has found a negative relationship (Eisdorfer 2008; Arif, Marshall, and Yohn 2016). A potential concern is that the relationship does not exist within my sample because of some feature of the customersupplier sample. I investigate this concern by expanding the sample to include all firms with necessary data from 2001-2016. Table 3 panel B shows the estimation of equation (1) within the expanded sample. Similar to the results within my sample, I do not detect a negative relationship between expected volatility and capital expenditures within the broader sample. Additionally, both estimations indicate that one standard deviation change in Expected_Volatility is associated with approximately a .4\% decrease in investment in working capital or a $.77 \%$ decrease in investment in working capital assets, as a percentage of total assets. This indicates that the results from panel A are not just a feature of my sample of suppliers, but that the empirical relation between capital expenditures and volatility is different in the more recent time period that I investigate (2001-2013) than in the longer time periods used by other studies ${ }^{15}$. In contrast, table 3 panel C shows the same estimation with a sample from 1964-2000 that precedes my study. Similar to prior work, I find the negative relationship between expected volatility and capital expenditures.

15 For example, Arif et al. (2016) examine 1964-2013. 
Because I am interested in how CIQ affects this relationship, I focus on working capital and working capital assets as proxies for investment for the remainder of my tests. 
Chapter 4. Research Design and Results

\subsection{The Effect of CIQ on Supplier Uncertainty}

In this section I investigate the relationship between a customer's information quality, the supplier's uncertainty, and the supplier's investment levels. I hypothesize that when a customer shares high-quality information with suppliers, the information reduces supplier uncertainty, and the reduced uncertainty causes the supplier to increase investment levels. My first set of hypotheses focuses on the scenario in which the customer's shared information is not completely private and is somewhat impounded into the supplier's stock volatility. To test this hypothesis, I examine the observable associations along the theoretical causal chain (Leuz and Wysocki 2016) illustrated in Figure 1.

H1a tests link A from figure 1 in the chain, the effect of CIQ on observed supplier uncertainty. H1a predicts that CIQ has a negative effect on the supplier's observed uncertainty. To test this prediction, I regress the supplier's observed uncertainty proxy, Expected Volatility, on CIQ proxies. I include Size as a control for its information environment, Market-to-Book because growth firms are more volatile, Leverage because more highly levered firms experience more drastic changes in equity prices, and $C F O$ as a common determinant of volatility. I control for Recession, Default_Spread, and Interest_Rate because macroeconomic conditions are highly associated with uncertainty. I include fixed effects for the supplier's two digit SIC code to account for unobservable 
industry differences that are related to the customer's propensity to disclose and the supplier's investment levels. Finally, I control for aspects of the customer firm that are associated with the propensity to disclose management forecasts. I estimate the following OLS regression to test H1a:

$$
\begin{aligned}
& \text { Expected_Volatility }_{i t}=\alpha+\beta_{1} \text { CIQ }_{j t}+\beta_{2} \text { Size }_{i t}+\beta_{3} \text { MTB }_{i t}+\beta_{4} \text { Leverage }_{i t}+\beta_{5} C F O_{i t} \\
& +\beta_{6} \text { Capital_Intensity }{ }_{i t}+\beta_{7} \text { Cust_Analyst_Accuracy }{ }_{j t}+\beta_{8} C u s t \_S T D \_R O A_{j t}+ \\
& \beta_{9} \text { Cust_Horizon }{ }_{j t}+\beta_{10} \text { Cust_Size } e_{t}+\beta_{11} \text { Cust_MTB }{ }_{j t}+\beta_{12} \text { Recession }{ }_{i t+1}+ \\
& \beta_{13} \text { Default_Spread }_{i t+1}+\beta_{14 \text { Interest_Rate } i t+1}+\psi+\epsilon_{i j t}
\end{aligned}
$$

Where $i$ indexes the supplier firm, $j$ indexes the customer firm and $t$ indexes the fiscal year. I use two-way clustering on the supplier and customer level to account for correlated errors that arise from matching suppliers to multiple customers and vice versa.

Table 4 Panel A shows results from estimating equation (2) within my sample of suppliers. The dependent variable is the supplier's expected volatility as of the end of year $t$ and has been standardized to have 0 mean and unit variance. The coefficient on $R E V$ indicates that supplier's expected volatility is approximately .2 standard deviations lower when its customer issues a sales forecast. The coefficient on $M F$ is not significantly different from 0 , suggesting that the information underlying a customer's earnings forecast does not affect the supplier's uncertainty. Control variables indicate that larger suppliers with higher cash flows are less volatile, while more leveraged suppliers are more volatile. 
The customer's earnings volatility is associated with higher expected volatility at the supplier and expected volatility is .6 standard deviations higher during recessions.

These results are consistent with a negative relationship between customer information quality and the supplier's uncertainty. The relation between $\operatorname{Rev}$ and Expected_Volatility suggests that at least some of the shared information is publicly observable. The differential results between $R E V$ and $M F$ indicate that high-quality information about future demand is particularly useful in mitigating a supplier's uncertainty.

$\mathrm{H} 1 \mathrm{~b}$ predicts that CIQ has a positive effect on investment levels. (see figure 1, line c). I estimate the following equation to test this hypothesis:

$$
\begin{aligned}
& \text { Investment }_{i t+1}=\alpha+\gamma_{1} \text { CIQ }_{j t}+\gamma_{2} \text { Size }_{i t}+\gamma_{3} \text { MTB }_{i t}+\gamma_{4} \text { Leverage }_{i t}+\gamma_{5} \mathrm{CFO}_{i t}+
\end{aligned}
$$

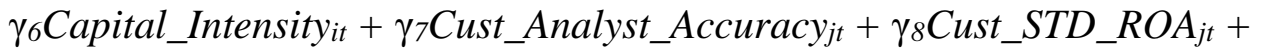

$$
\begin{aligned}
& \gamma_{9} \text { Cust_Horizon }{ }_{j t}+\gamma_{10} \text { Cust_Size }_{j t}+\gamma_{11} \text { Cust_MTB }_{j t}+\gamma_{12} \text { Recession }_{i t+1}+ \\
& \gamma_{13} \text { Default_Spread }_{i t+1}+\gamma_{14} \text { Interest_Rate }_{i t+1}+\psi+\epsilon_{i j t}
\end{aligned}
$$

The results from estimating equation (3) using $W C$ as the proxy for investment are presented in table 4 panel $\mathrm{B}$. The positive coefficient on $R E V$ in the first column indicates that suppliers invest $0.68 \%$ more of total assets into working capital when customers issue sales guidance. This represents approximately a .09 (0.68/7.402) standard deviation increase in working capital investment when a customer issues a revenue forecast. In 
contrast, there is no statistical association between the customer's issuance of an earnings forecast and the supplier's investment in working capital.

To test hypothesis H1c, that uncertainty mediates the relation between customer information quality and supplier investment, I next add Expected_Volatility as an independent variable to equation (3). If the relationship between investment and CIQ is mediated by uncertainty, then the coefficient from regressing investment on CIQ should be lower when including uncertainty. Columns 2 and 4 show the results of these estimations, with Column 5 showing a statistical test of the differences in estimated coefficients. The coefficient on Rev decreases by 10\% when including Expected_Volatility, but the reduction is only significant at $\alpha=.11$, slightly below conventional levels. This provides weak evidence that the association between customer sales forecasts and supplier investment is mediated by uncertainty.

Table 4 panel C shows estimates of equation (3) using WC Assets as the proxy for investment. The results are similar to those in panel B. Customer sales forecasts are associated with an increase in investment but customer earnings forecasts are not. Column 5 shows that the relationship between WC Assets and Rev is significantly weaker when including Expected_Volatility in the regression, providing evidence that the relationship between CIQ and investment is partially mediated by uncertainty. The coefficients indicate that $16 \%(0.13 / 0.821)$ of the investment effect of a sales forecast on investment is due to the observable relationship between Rev and Expected_Volatility. The remaining relationship between CIQ and supplier investment is either due to an unobservable effect of CIQ on the supplier's uncertainty or some other mechanism through which the 
customer's information affects supplier investment. I do not observe a relationship between $M F$ and the supplier's volatility or investment. The combined results when using Rev and $M F$ indicate that the customer's demand information is particularly relevant to suppliers.

\subsection{Mitigating the Effect of Uncertainty}

My next set of tests examines the effect of CIQ on the supplier's sensitivity to observed uncertainty. The key assumption that differentiates this design from the set of tests in the prior section is that the measure of supplier uncertainty does not completely reflect the information shared between the customer and supplier. My design follows prior literature that examines factors that mitigate the effect of observed uncertainty on investment (Wellman 2017; Czarnitzki and Toole 2007; Czarnitzki and Toole 2011). Each of these studies regresses investment on an observed measure of uncertainty (e.g. policy uncertainty in Wellman 2017), the mitigating factor (e.g., political connectedness), and the interaction between the two. Prior studies interpret a positive coefficient on the interaction as evidence that the factor of interest mitigates the effect of the observed uncertainty on the firm's beliefs about returns on investment, thus reducing the firm's investment sensitivity to observed uncertainty. Similarly, I test my hypothesis by regressing investment on Expected_Volatility, CIQ, and the interaction between the two ${ }^{16}$.

\footnotetext{
${ }^{16}$ Some studies in accounting and economics focus on the effect of uncertainty on responsiveness to growth opportunities (Guiso and Parigi 1999; Bloom, Bond, and Van Reenen 2007; Badertscher, Shroff, and White 2013). However, I follow the literature that is most closely related to my question and focus on the direct effect of uncertainty on investment.
} 


$$
\begin{aligned}
& \text { Invest }_{i t+1}=\alpha+\beta_{1} C I Q_{j t}+\beta_{2} \text { Expected_Volatility }_{i t}+\beta_{3} \text { CIQ }_{j t} * \text { Expected_Volatility }_{i t} \\
& +\beta_{4} \text { Size }_{i t}+\beta_{5} \mathrm{MTB}_{i t}+\beta_{6} \text { Leverage }_{i t}+\beta_{7} C F \mathrm{O}_{i t}+\beta_{8} \text { Capital_Intensity }_{i t}+ \\
& \beta_{9} \text { Cust_Analyst_Accuracy }{ }_{j t}+\beta_{10} \text { Cust_Analyst_Accuracy }{ }_{j t}{ }^{*} \text { Expected_Volatility }_{i t}+ \\
& \beta_{11} \text { Cust_STD_ROA }{ }_{j t}+\beta_{12} C u s t \_H o r i z o n_{j t}+\beta_{13} C u s t \_S i z e e_{j t}+\beta_{14} C u s t \_M T B_{j t}+ \\
& \beta_{15} \text { Recession }_{i t+1}+\beta_{16} \text { Default_Spread }_{i t+1}+\beta_{17 \text { Interest_Rate }} \text { It }+1_{1}+\psi+\epsilon_{i j t}
\end{aligned}
$$

I control for the relationship between CIQ and investment, so $\beta_{3}$ captures the differential impact of uncertainty on investment for suppliers that have customers issuing either sales or earnings forecasts. In addition to controls used in prior specifications, I include an interaction between the customer's analyst accuracy and expected volatility to control for factors in the customer's information environment that also effect the supplier's uncertainty.

Table 5 shows estimations of equation (4) with $W C$ as the dependent variable in columns one and three and WC Assets as the dependent variable in columns two and four. The first two columns show that the main positive effect of $R E V$ and negative effect of Expected_Volatility are still significant, but the negative effect of uncertainty is attenuated for suppliers when their customers issue sales forecasts. I test the sum of $\beta_{2}$ and $\beta_{3}$ and find that the sum is not significantly different from zero when using Rev to proxy for CIQ, which indicates that the relationship between volatility and investment is fully attenuated by the customer's information. Suppliers whose customers issue revenue forecasts are not sensitive to observed uncertainty, consistent with relevant, precise information having a strong effect on the supplier's final information set. Consistent with results in the previous 
section, the supplier's sensitivity to volatility is not attenuated by a customer's earnings forecast, which is indicative of the importance of demand-related information.

The combined results from chapters 4.1 and 4.2 indicate that the customer's demand-related information reduces the supplier's uncertainty and increases investment. The partial mediation in the first set of tests and the full attenuation in the second set are both consistent with the customer sharing information with the supplier and a substantial portion of that information remaining private.

\subsection{More Economically Important Relationships}

I test my next set of hypotheses by examining the effect of CIQ in subsamples where it is more likely to have a strong effect vs. a weaker effect (Bamber, Christensen, and Gaver 2000). Pandit et al. (2012) find that customer earnings surprises are more meaningful to suppliers that have a higher proportion of sales going to that customer, suggesting that the customer's information is more important when the customer makes up a larger proportion of sales. I test whether the customer's information has a stronger effect on the supplier's uncertainty when there is a higher proportion of sales going to the customer by calculating Sale_Pct as the percentage of a supplier's sales that go to the customer. I then re-estimate equation 2-4 within the separate samples that are above and below median Sale_Pct, labeled important customer and unimportant customer subsamples respectively. I test whether the effect of a customer's information is stronger in the important customer subsample than the unimportant customer subsample to test $\mathrm{H} 3$ and $\mathrm{H} 4$. 
Table 6 panel A shows the estimations of equation (2) within the different subsamples. I do not find evidence that CIQ has a stronger effect on volatility in the sample with a larger proportion of sales going to a supplier. Rev has a significant negative effect in both groups, while $M F$ has no effect and there is no difference between the groups. Panels B and C show estimations of equation (3) with WC and WC Assets as the respective dependent variables. Again, the results in each subsample are similar to those found in the full sample with Rev having a significant effect in both groups and $M F$ having no discernible effect.

Table 6 Panel D displays estimations of equation (4) in the important customer and unimportant customer subsamples. $\mathrm{H} 4$ predicts that the interaction term in the important customer subsample will be larger than the same term in the unimportant customer subsample. I find that the interaction term is greater in the subsample of important customers than in the subsample of unimportant customers, although the difference between the two is statistically insignificant. Taken together, the results in Panels A through D do not provide evidence that the effect of CIQ is stronger when the customersupplier relationship is more economically important to the supplier.

I further investigate the cross-sectional difference in the effect of CIQ on investment by splitting the sample based on the importance of the supplier to the customer. If purchases from the supplier account for a higher proportion of the customer's cost of goods sold then I assume that the supplier is more important to the customer . Customers are more likely to share information with important suppliers and the customer's general information generation process should be more relevant to the supplier. Thus, I measure 
the supplier's sales to the customer scaled by the customer's cost of goods sold and split the sample on the median. I compare the effect of CIQ in the subsample that is above median in both of the splits (important $C \& S$ ) compared to the sample that is below median in both of the splits (unimportant $C \& S$ ) in my next set of tests.

Table 6 panel E displays estimations of equation (2) between the different subsamples. Again, there is not a significant difference in the effect of CIQ across the important $C \& S$ and unimportant $C \& S$ subsamples. Panels $\mathrm{F}$ and $\mathrm{G}$ also show that there is not a detectable difference in the effect of CIQ on investment across the samples. Panel H shows that the effect on the supplier's investment sensitivity does not vary as well. Overall, these results do not provide evidence that the effect of the supplier's information varies based on the importance of the customer-supplier relationship and provides no support for $\mathrm{H} 3$ or $\mathrm{H} 4$. One possible explanation for this result is that information from a major customer has a similar effect on the supplier's decision making, so long as that information can be extrapolated to the rest of the supplier's operations. Because all of the customers in my sample are economically important to the suppliers, the cross-sectional differences in economic importance may not predict the relevance of the customer's information. 


\section{Chapter 5. Additional Tests}

\subsection{Restatements}

I further investigate the relationship between CIQ and supplier investment levels by using customers' restatements as an additional proxy for low CIQ. Prior research has demonstrated that restatements are related to the quality of a firm's internal information, which can be shared with suppliers (Gallemore and Labro 2015). I obtain restatement data from Audit Analytics, which allows me to expand the sample to include customer-supplier pairs from 1997-2016, resulting in 11,261 observations. No_Error is an indicator variable for customers that do not restate financial statements for the three year period ending in year $t$.

Table 7 shows results from estimating equations 2-4 within this sample using No_Error for CIQ. Panel A shows that customer restatements are not related to the supplier's expected volatility or working capital investment. Panel B shows tests for restatements mitigating the effect of uncertainty on investment. I find that the relationship between expected volatility and investment in working capital assets is attenuated when customers do not have a restatement, but it is not statistically significant when examining investment in all working capital. Results also indicate that the negative effect of uncertainty on investment is fully attenuated when the customer does not restate. This

provides more evidence, albeit weak, that CIQ mitigates the effect of uncertainty on 
supplier investment and is consistent with the non-public nature of restatements before their announcement.

\subsection{Forecasting Accuracy}

Empirical literature links the accuracy of a firm's earnings forecasts to the quality of its internal information (Goodman et al. 2014; Ittner and Michels 2017). I build on this line of literature and use the accuracy of a customer's sales forecasts (Rev_Accuracy) and earnings forecasts (Earn_Accuracy) as additional measures of CIQ. This requires customers to issue sales or earnings forecasts, which limits the sample to 3,380 and 6,052 observations respectively.

Table 8 panel A shows estimations of equations (2) and (3) using Rev_Accuracy. Column 1 shows a negative relation between Rev_Accuracy and expected volatility, consistent with H1a. However, the remaining estimations show that there is no effect on investment. Panel B does not show evidence that Rev_Accuracy is related to the supplier's internal information set, failing to support $\mathrm{H} 2$. I find that the effect of uncertainty on investment is fully attenuated when the customer issues a sales forecast, hence the weak relationship within the subsample of customers that issue sales forecasts is not surprising.

Table 9 shows the results from estimating equations 2-4 using Earn_Accuracy as a measure of CIQ. Panel A shows that Earn_Accuracy is not significantly related to either the supplier's volatility, or its investment in working capital and Panel B shows that the customer's accuracy does not mitigate the effect of uncertainty on investment. Collectively, these results do not provide evidence for my hypotheses. 
One possible explanation for why the results in prior research do not carry over to my setting is the difference in sample composition. In particular, my results are based on a limited sample of customers that already have higher-quality information than customers that do not forecast. Table 2 panel D displays the distribution of Earn_Accuracy within my sample compared to the more general sample of forecasters. Earn_Accuracy is higher across the distribution within the customer-supplier sample (mean of -0.007 compared to 0.017) and compared to the results in Goodman et al. (2014) (mean of -0.024). However, Rev_Accuracy is not more accurate in the sample of major customers.

\subsection{Internal Control Weaknesses}

All public companies are required to perform tests of their internal control systems. Internal controls weaknesses indicate that a company has poor information quality and prior research indicates that this information quality affects customer-supplier relationships (Gallemore and Labro 2015, Henderson et al. 2017). I follow this research and use a company's publicly disclosed internal control weaknesses as a proxy for low CIQ.

I consider a customer to have low-quality information if it has a material internal control weakness during the year of investment. I use an indicator variable, No_MW, that equals 1 if a firm does not have a material weakness in year $t+1$ so the expected relationship between CIQ and uncertainty is negative. This procedure limits my sample to 2004-2016, resulting in 4,875 observations. Panel A of Table 10 displays estimations of equations (2) and (3) within this sample. There is no significant relationship between customer internal control weaknesses and supplier volatility or investment levels. Panel B displays tests of 
H2 using internal control weaknesses. Column 2 shows that the supplier's investment levels are more sensitive to uncertainty when the supplier's customer has a material weakness in internal controls, consistent with $\mathrm{H} 2$. (That is, when a customer doesn't report an internal control weakness, the supplier is less sensitive to uncertainty.) The coefficients indicate that the effect of uncertainty on the supplier's investment is fully attenuated by the lack of a customer's internal control weakness. The support for H2, but not H1, suggests that shared information related to internal control weaknesses remains private and is not impounded in the supplier's expected volatility.

\subsection{Excluding Walmart}

Table 2 panel A shows that Walmart represents a substantial portion of the customers observations in my sample. Walmart's disclosure choices, the information that it shares with suppliers, or the nature of Walmart's suppliers could drive the results that I find. To alleviate this concern I rerun my primary tests, excluding observations where Walmart is the customer. This leaves 7,660 customer-supplier observations for inspection.

Table 11 Panel A shows estimations of equation (2) using this subsample. The main result that revenue forecasts are associated with lower supplier volatility but earnings forecasts are not continues to hold in this sample. Panels B and C show that revenue forecasts are positively associated with investment in working capital, while earnings forecasts are not. They also show that the relationship between Rev and investment is partially mediated by uncertainty, consistent with results in Table 4 . The coefficients on Rev are of consistently greater magnitude and statistical significance when excluding 
Walmart. Panel D provides the tests for $\mathrm{H} 2$ within this subsample. I continue to find that the effect of volatility on investment in working capital is weaker when customers issue a sales forecast, but not an earnings forecast. I continue to find that the effect of uncertainty is fully attenuated when the customer issues a sales forecast. The only notable difference between this table and the main results is that the mitigating effect on investment in working capital is only significant at $\alpha=.08$ (two-sided). Collectively, these results provide evidence that the support I find for $\mathrm{H} 1$ and $\mathrm{H} 2$ is not due to Walmart's effect within my sample. 


\section{Chapter 6. Conclusion}

A firm's suppliers are stakeholders in the firm and rely on the information that they receive from the customer. I investigate how the customer's information quality (CIQ) affects investment decisions by the supplier. The literature on investment under uncertainty finds that a firm's investment levels are related to the precision of information about returns on investment. I propose that when customers share high-quality information with their suppliers the suppliers face less uncertainty and have higher overall investment.

I use the customer's voluntary sales and earnings guidance as proxies for its information quality and the supplier's expected volatility as a proxy for uncertainty. Because the supplier's volatility is publicly observable and the information that customers share can be public or private, I examine the relation between CIQ and supplier investment in two ways. The first approach allows for the customer's information to be incorporated into the supplier's stock price volatility and examines the links between CIQ, supplier uncertainty, and supplier investment. I find that when a customer issues a sales forecast its supplier has lower expected volatility and higher investment in working capital. The relationship between the customer's sales forecasts and the supplier's investment is mediated by expected volatility. However, I do not observe these same relationships when a customer issues an earnings forecast. These results provide evidence that the customer's 
information quality regarding demand affects the supplier's uncertainty, thereby affecting investment.

My second approach accounts for the possibility that shared information remains private and the supplier's expected volatility does not incorporate the customer's information. A wider gap between the supplier's actual uncertainty and the observed uncertainty implies a weaker relation between observed uncertainty and the supplier's investment. I find that when a customer issues sales forecasts the relationship between investment and volatility at the supplier is weaker. Again, I do not find the same effect from an earnings forecast. This provides further evidence that the customer's demandrelated information quality affects the supplier's investment decisions by altering the supplier's uncertainty.

I perform cross-sectional tests based on the importance of the customer and supplier in the relationship. I do not find that sales forecasts have a stronger effect when one party is particularly important. I investigate alternative proxies for the customer's information quality including forecasting accuracy, internal control weaknesses, and restatements. I continue to find some evidence that CIQ attenuates the relationship between investment and uncertainty when using restatements and internal control weaknesses, but I do not find evidence that they are related to the supplier's observed uncertainty. I do not find any evidence that the customers sales or earnings forecasting accuracy are related to the supplier's investment levels, possibly due to the fact that these tests are performed within a subsample that already possesses high information quality. Finally, because Walmart 
makes up a substantial portion of the customer observations in my sample, I exclude Walmart as a customer and draw the same conclusions.

My results add to the literature on investment under uncertainty by demonstrating that demand-related information from a customer can reduce a supplier's uncertainty and increase investment in working capital. Theory on the relationship between investment and uncertainty suggests that this additional investment reduces the dead-weight loss caused by uncertainty (Dixit and Pindyck 1994). This study also adds to the literature in accounting that examines how information coming from a customer is useful for a supplier and adds to the broader literature that examines the spillover of information from one firm to another (Cohen and Frazzini 2008; Raman and Shahrur 2008; Pandit, Wasley, and Zach 2011; Bauer, Henderson, and Lynch 2017) . Finally, I provide further evidence that publicly disclosed forecasts are a valid proxy for the quality of its internal information by examining forecasts in a setting that is known to have substantial private information flow (Verrecchia 1990; Goodman et al. 2014; Ittner and Michels 2017).

Overall, this study provides initial evidence that a customer's information quality affects the supplier's decision making. The role of information sharing along the supply chain should be of interest to the academic accounting community. Future research may include the effect of the customer's information quality on other operational areas such as inventory management and operational efficiency. 


\section{Bibliography}

Abel, By Andrew B. 1983. "American Economic Association Optimal Investment Under Uncertainty Author ( s ): Andrew B . Abel Source: The American Economic Review, Vol . 73 , No . 1 ( Mar ., 1983 ), Pp . 228-233 The American Economic Review 73 (1): 228-33.

Abel, By Andrew B, and Janice C Eberly. 1994. "American Economic Association A Unified Model of Investment Under Uncertainty." The American Economic Review 84 (5): 1369-84.

Andon, Paul, Jane Baxter, and Wai Fong Chua. 2015. "Accounting for Stakeholders and Making Accounting Useful.” Journal of Management Studies 52 (November): 9861002. doi:10.1111/joms.12142.

Arif, Salman, Nathan Marshall, and Teri Lombardi Yohn. 2016. "Understanding the Relation between Accruals and Volatility: A Real Options-Based Investment Approach." Journal of Accounting and Economics 62 (1). Elsevier: 65-86. doi:10.1016/j.jacceco.2016.04.005.

Badertscher, Brad, Nemit Shroff, and Hal D White. 2013. "Externalities of Public Firm Presence : Evidence from Private Firms' Investment Decisions." Journal of Financial Economics 109 (3). Elsevier: 682-706. doi:10.1016/j.jfineco.2013.03.012.

Baker, Scott R, Nicholas Bloom, and Steven J Davis. 2016. "Measuring Economic Policy Uncertainty." The Quarterly Journal of Economics 131 (November): 1593-1636. doi:10.1093/qje/qjw024.Advance.

Bamber, Linda Smith, Theodore E. Christensen, and Kenneth M. Gaver. 2000. "Do We Really 'Know' What We Think We Know? A Case Study of Seminal Research and Its Subsequent Overgeneralization." Accounting, Organizations and Society 25 (2): 103-29. doi:10.1016/S0361-3682(99)00027-6.

Baron, Reuben, and David Kenny. 1986. "The Moderator-Mediator Variable Distinction in Social Psychological Research.” Journal of Personality and Social Psychology 51 (6): 1173-82. doi:10.1037/0022-3514.51.6.1173.

Barron, O. E., \& Stuerke, P. S. (1998). Discussion: "Dispersion in Analysts" Earnings Forecast as a Measure of Uncertainty"." Journal of Accounting Auditing \& Finance, 13(3), 271-274.

Bauer, Andrew, Darren Henderson, and Daniel Lynch. 2017. "Supplier Internal Control Quality and the Duration of Customer-Supplier Relationships." The Accounting Review, Forthcoming.

Beatty, Anne, Scott Liao, and Jeff Jiewei Yu. 2013. "The Spillover Effect of Fraudulent Financial Reporting on Peer Firms' Investments." Journal of Accounting and Economics 55 (2-3). Elsevier: 183-205. doi:10.1016/j.jacceco.2013.01.003.

Bernanke, Ben S. 1983. "Irreversibility, Uncertainty, and Cyclical Investment." The Quarterly Journal of Economics, February.

Bloom, Nick, Stephen Bond, and John Van Reenen. 2007. "Uncertainty and Investment Dynamics.” Review of Economic Studies 74: 391-415. 
Bonsall, S. B., Holzman, E. R., \& Miller, B. P. (2018). The Role of Management Talent in the Production of Informative Regulatory Filings. Working Paper, The Ohio State University.

Bozanic, Z., D. T. Roulstone, and A. Van Buskirk. 2018. Management Earnings Forecasts and Other Forward-Looking Statements. Journal of Accounting and Economics 65 (1): 1-20.

Bulan, Laarni, Christopher Mayer, and C Tsuriel Somerville. 2009. "Irreversible Investment, Real Options, and Competition : Evidence from Real Estate Development." Journal of Urban Economics 65 (3). Elsevier Inc.: 237-51. doi:10.1016/j.jue.2008.03.003.

Bulan, Laarni T. 2005. "Real Options , Irreversible Investment and Firm Uncertainty: New Evidence from U . S . Firms." Review of Financial Economics 14: 255-79. doi:10.1016/j.rfe.2004.09.002.

Caballero, Ricardo J. 1991. "On the Sign of the Investment-Uncertainty Relationship." The American Economic Review 81 (1): 279-88.

Cen, Ling, Edward L. Maydew, Liandong Zhang, and Luo Zuo. 2017. "Customersupplier Relationships and Corporate Tax Avoidance." Journal of Financial Economics 123 (2). Elsevier B.V.: 377-94. doi:10.1016/j.jfineco.2016.09.009.

Chen, Chen, Danqing Young, and Zili Zhuang. 2013. "Externalities of Mandatory IFRS Adoption: Evidence from Cross-Border Spillover Effects of Financial Information on Investment Efficiency." Accounting Review 88 (3): 881-914. doi:10.2308/accr50384.

Cohen, Lauren, and Andrea Frazzini. 2008. "Economic Links and Predictable Returns." The Journal of Finance LXIII (4): 1977-2011.

Costello, Anna M. 2013. "Mitigating Incentive Conflicts in Inter-Firm Relationships : Evidence from Long-Term Supply Contracts." Journal of Accounting and Economics 56 (1). Elsevier: 19-39. doi:10.1016/j.jacceco.2013.02.001.

Czarnitzki, Dirk, and Andrew A Toole. 2007. "Business R \& D and the Interplay of R \& D Subsidies and Product Market Uncertainty." Review of Industrial Organization 31: 169-81. doi:10.1007/s11151-007-9152-x.

- 2011. "Patent Protection, Market Uncertainty, and R\&D Investment." The Review of Economics and Statistics 93 (February): 147-59.

Dhaliwal, Dan S, Jaideep Shenoy, and Ryan Williams. 2016. "Common Auditors and Relationship-Specific Investment in Supplier-Customer Relationships." Working Paper, University of Arizona 2929.

Dietrich, J Richard. 2011. "Discussion of “" Information Externalities along the Supply Chain : The Economic Determinants of Suppliers " Stock Price Reaction to Their Customers ' Earnings Announcements " *." Contemporary Accounting Research 28 (4): 1344-48. doi:10.1111/j.1911-3846.2011.01128.x.

Dixit, Avinash K, and Robert S Pindyck. 1994. "Investment Under Uncertainty." Princeton University Press.

Eisdorfer, Assaf. 2008. "Empirical Evidence of Risk Shifting." The Journal of Finance LXIII (2). 
Fairfield, Patricia M., Scott Whisenant, and Teri Lombardi Yohn. 2003. “Accrued Earnings and Growth: Implications for Earnings Persistence and Market Mispricing." The Accounting Review 78 (1): 353-71. doi:10.2139/ssrn.249311.

Files, Rebecca, and Umit G. Gurun. 2017. 'Lenders' Response to Peer and Customer Restatements." Forthcoming in Contemporary Accounting Research, no. November.

Gallemore, John, and Eva Labro. 2015. "The Importance of the Internal Information Environment for Tax Avoidance." Journal of Accounting and Economics 60 (1). Elsevier: 149-67. doi:10.1016/j.jacceco.2014.09.005.

Goodman, Theodore H, Monica Neamtiu, Nemit Shroff, and Hal D White. 2014. "Management Forecast Quality and Capital Investment Decisions." The Accounting Review 89 (1): 331-65. doi:10.2308/accr-50575.

Guan, Yuyan, M H Franco Wong, and Yue Zhang. 2015. "Analyst Following along the Supply Chain.” Review of Accounting Studies, no. June 2014: 210-41. doi:10.1007/s11142-014-9295-6.

Guiso, Luigi, and Giuseppe Parigi. 1999. "Investment and Demand Uncertainty." The Quarterly Journal of Economics, no. February: 185-227.

Hartman, Richard. 1972. "The Effects of Price and Cost Uncertainty on Investment." Journal of Economic Theory 266 (5): 258-66.

Hemmer, Thomas, and Eva Labro. 2008. "On the Optimal Relation between the Properties of Managerial and Financial Reporting Systems." Journal of Accounting Research 46 (5): 1209-40. doi:10.1111/j.1475-679X.2008.00303.x.

Hutton, Amy P., Lian Fen Lee, and Susan Z. Shu. 2012. "Do Managers Always Know Better? The Relative Accuracy of Management and Analyst Forecasts." Journal of Accounting Research 50 (5): 1217-44. doi:10.1111/j.1475-679X.2012.00461.x.

Ittner, Christopher D., and Jeremy Michels. 2017. "Risk-Based Forecasting and Planning and Management Earnings Forecasts." Review of Accounting Studies 22 (3). Review of Accounting Studies: 1005-47. doi:10.1007/s11142-017-9396-0.

Johnstone, Karla M., Chan Li, and Shuqing Luo. 2014. "Client-Auditor Supply Chain Relationships, Audit Quality, and Audit Pricing." AUDITING: A Journal of Practice \& Theory 33 (4): 119-66. doi:10.2308/ajpt-50783.

Julio, Brandon, and Youngsuk Yook. 2012. "Political Uncertainty and Corporate Investment Cycles." The Journal of Finance LXVII (1): 45-83.

Leahy, John V., and Toni M Whited. 1996. "The Effect of Uncertainty on Investment : Some Stylized Facts Author." Journal of Money, Credit and Banking 28 (1): 64-83.

Lee, Hau L., V. Padmanabhan, and Seungjin Whang. 1997. "Information Distortion in a Supply Chain: The Bullwhip Effect.” Management Science 43 (4): 546-58. doi:10.1287/mnsc.43.4.546.

Lee, Hau L., and Seungjin Whang. 2000. "Information Sharing in a Supply Chain." International Journal of Manufacturing Technology and Management 1 (1): 79. doi:10.1504/IJMTM.2000.001329.

Leuz, C., \& Wysocki, P. D. (2016). The Economics of Disclosure and Financial Reporting Regulation: Evidence and Suggestions for Future Research. Journal of Accounting Research, 54(2), 525-622. https://doi.org/10.1111/1475-679X.12115 
Luo, Shuqing, and Nandu J Nagarajan. 2015. "Information Complementarities and Supply Chain Analysts.” The Accounting Review 90 (5): 1995-2029. doi:10.2308/accr-51011.

Madsen, Joshua. 2017. "Anticipated Earnings Announcements and the Customer Supplier Anomaly." Journal of Accounting Research 55 (3): 709-41. doi:10.1111/1475-679X.12158.

Mayew, W. J., Sethuraman, M., \& Venkatachalam, M. (2015). MD\&A disclosure and the firm's ability to continue as a going concern. Accounting Review, 90(4), 1621-1651. https://doi.org/10.2308/accr-50983

McDonald, Robert, and Daniel Siegel. 1986. "The Value of Waiting to Invest." The Quarterly Journal of Economics, no. November.

McNichols, Maureen F., and Stephen R. Stubben. 2008. "Does Earnings Management Affect Firms' Investment Decisions?" Accounting Review 83 (6): 1571-1603. doi:10.2308/accr.2008.83.6.1571.

Ogawa, Kazuo, and Kazuyuki Suzuki. 2000. "Uncertainty and Investment: Some Evidence From the Panel Data of Japanese Manufacturing Firms." The Japanese Economic Review 51 (2): 170-92.

Olsen, Chris, and J Richard Dietrich. 1985. "Vertical Information Transfers : The Association between Retailers' Sales Announcements and Suppliers' Security Returns." Journal of Accounting Research 23 (1985): 144-66.

Pandit, Shail, Charles E Wasley, and Tzachi Zach. 2011. "Information Externalities along the Supply Chain : The Economic Determinants of Suppliers' Stock Price Reaction to Their Customers ' Earnings Announcements *." Contemporary Accounting Research 28 (4): 1304-43. doi:10.1111/j.1911-3846.2011.01092.x.

Raman, Kartik, and Husayn Shahrur. 2008. "Relationship-Specific Investments and Earnings Management : Evidence on Corporate Suppliers and Customers." The Accounting Review 83 (4): 1041-81. doi:10.2308/accr.2008.83.4.1041.

Trueman, Brett. 1986. "Why Do Managers Voluntarily Release Earnings Forecasts?" Journal of Accounting and Economics 8 (1): 53-71. doi:10.1016/01654101(86)90010-8.

Verrecchia, Robert E. 1990. "Information Quality and Discretionalry Disclosure." Journal of Accounting and Economics 12 (4): 365-80. doi:10.1016/01654101(90)90021-U.

Wellman, Laura A. 2017. Mitigating Political Uncertainty. Review of Accounting Studies. doi:10.1007/s11142-016-9380-0.

Zhang, Bobo, and Zhou Zhang. 2016. "The Spillover Effect of Corporate Fraud : Evidence from Firm Level Supply Chain Data.” Working Paper, University of Warwick.

Zhang, X. Frank. 2007. "Accruals, Investment, and the Accrual Anomaly." Accounting Review 82 (5): 1333-63. doi:10.2308/accr.2007.82.5.1333.

Zhao, Xinshu, John G. Lynch, and Qimei Chen. 2010. "Reconsidering Baron and Kenny: Myths and Truths about Mediation Analysis." Journal of Consumer Research 37 (2): 197-206. doi:10.1086/651257. 


\section{Appendix A: Tables and Figures}

\section{Table 1: Sample Composition}

This table provides an overview of some sample characteristics. Panel A provides the 1digit SIC industry code of suppliers in the sample. Panel B lists the most common customers in the sample and the number of observations for each.

Panel A: Industry Composition

\begin{tabular}{|l|r|r|}
\hline One Digit SIC & Supplier Observations & \multicolumn{1}{|c|}{$\%$} \\
\hline 0 - Agriculture & 4 & 0.05 \\
1 - Mining and Construction & 382 & 4.36 \\
2 - Manufacturing & 2,291 & 26.14 \\
3 - Manufacturing & 3,914 & 44.65 \\
4 - Transportation & 299 & 3.41 \\
5 - Wholesale and Retail & 570 & 6.5 \\
7 - Services & 893 & 10.19 \\
8 - Services & 334 & 3.81 \\
9 - Public Administration & 78 & 0.89 \\
\hline
\end{tabular}




\section{Table 1 continued}

Panel B: Common Customers

\begin{tabular}{|r|l|c|}
\hline & Name & Count \\
\hline 1 & Wal-Mart & 1,102 \\
2 & Cardio Dynamics & 315 \\
3 & McKesson Corp & 252 \\
4 & Amerisource Health & 237 \\
5 & Ford & 194 \\
6 & Dayton Hudson (Target) & 192 \\
7 & Bell Atlantic (Verizon) & 190 \\
8 & Hewlett-Packard & 186 \\
9 & Home Depot & 179 \\
10 & General Electric & 175 \\
\hline
\end{tabular}




\section{Table 2: Descriptive Statistics}

This table provides descriptive statistics for the sample that I use in subsequent tests. Panel A displays distributional properties of variables used in tests. Panel B provides comparison of means between observations with a customer issuing a sales forecast (Rev=1) and those that do not have a customer sales forecast. Panel $\mathrm{C}$ provides means for subsamples where a customer issues a sales forecast, an earnings forecast, both, or neither. Panel D displays the distributional properties of the accuracy of a customer's revenue and earnings forecasts for the sample of customers that provide an earnings forecast compared to the population of $\mathrm{I} / \mathrm{B} / \mathrm{E} / \mathrm{S}$ that meets all of my sample restrictions during the same time period. Panel $\mathrm{E}$ displays the correlation matrix of relevant variables. Correlations that are significant at $\alpha$ $<.05$. All variables are defined in Appendix B. Size and Cust_Size are presented in millions of dollars, not logged, for ease of interpretation. Continuous variables are winsorized at the $1^{\text {st }}$ and $99^{\text {th }}$ percentiles.

Panel A: Descriptive Statistics

\begin{tabular}{lcccccc} 
Variable & $\mathbf{N}$ & mean & $\mathbf{p 5 0}$ & $\mathbf{p 2 5}$ & $\mathbf{p 7 5}$ & sd \\
\hline Investment, Uncertainty, CIQ & & & & & & \\
Capex & 8,765 & 4.584 & 2.793 & 1.501 & 5.108 & 5.780 \\
WC & 8,765 & 0.547 & 0.339 & -2.731 & 3.726 & 7.402 \\
WC_Assets & 8,765 & 1.997 & 1.179 & -2.061 & 5.279 & 9.543 \\
Expected_Firm_Volatility & 8,765 & 0.035 & 0.030 & 0.022 & 0.043 & 0.020 \\
Rev & 8,765 & 0.386 & 0.000 & 0.000 & 1.000 & 0.487 \\
MF & 8,765 & 0.691 & 1.000 & 0.000 & 1.000 & 0.462 \\
Earn_accuracy & 6,056 & -0.007 & -0.003 & -0.007 & -0.001 & 0.011 \\
Supplier Controls & & & & & & \\
CFO & 8,765 & 0.069 & 0.101 & 0.021 & 0.163 & 0.173 \\
Size & 8,765 & 3,901 & 387 & 105 & 1,519 & 13,863 \\
MTB & 8,765 & 3.106 & 2.024 & 1.245 & 3.503 & 3.495 \\
Lev & 8,765 & 0.429 & 0.422 & 0.243 & 0.590 & 0.220 \\
Customer Controls & & & & & & \\
Cust_MTB & 8,765 & 3.632 & 2.877 & 1.802 & 4.124 & 2.968 \\
Cust_Analyst_Accuracy & 8,765 & -0.011 & -0.005 & -0.013 & -0.002 & 0.018 \\
Cust_Size & 8,765 & 75,120 & 31,319 & 9,111 & 114,907 & 90,864 \\
Cust_STD_ROA & 8,765 & 0.012 & 0.006 & 0.003 & 0.013 & 0.017 \\
Sale_PCT & 8,596 & 0.190 & 0.150 & 0.110 & 0.221 & 0.142 \\
\hline
\end{tabular}

Continued 
Table 2 Continued

Panel B: Comparison of High CIQ to Low CIQ by REV

\begin{tabular}{lcccccc} 
& \multicolumn{2}{c}{$\mathrm{Rev}=1$} & \multicolumn{2}{c}{$\mathrm{Rev}=0$} \\
Variable & $\mathbf{N}$ & Mean & $\mathbf{N}$ & Mean & Difference & T-Stat \\
\hline Investment, Uncertainty, CIQ & & & & & & \\
Capex & 3,387 & 3.612 & 5,378 & 5.196 & -1.584 & -3.41 \\
WC & 3,387 & 1.057 & 5,378 & 0.226 & 0.830 & 3.59 \\
WC_Assets & 3,387 & 2.688 & 5,378 & 1.562 & 1.127 & 3.67 \\
Expected_Firm_Volatility & 3,387 & 0.033 & 5,378 & 0.037 & -0.005 & -3.54 \\
Supplier Controls & & & & & & \\
CFO & 3,387 & 0.053 & 5,378 & 0.079 & -0.025 & -2.66 \\
Size & 3,387 & 4,400 & 5,378 & 3,587 & 812 & 0.75 \\
MTB & 3,387 & 3.277 & 5,378 & 2.999 & 0.277 & 1.43 \\
Lev & 3,387 & 0.415 & 5,378 & 0.439 & -0.024 & -1.72 \\
Customer Controls & & & & & & \\
Cust_MTB & 3,387 & 3.229 & 5,378 & 3.885 & -0.656 & -1.73 \\
Cust_Analyst_Accuracy & 3,387 & -0.009 & 5,378 & -0.012 & 0.003 & 1.25 \\
Cust_Size & 3,387 & 64,411 & 5,378 & 81,865 & $-17,455$ & -0.96 \\
Cust_STD_ROA & 3,387 & 0.010 & 5,378 & 0.013 & -0.002 & -1.39 \\
Sale_PCT & 3,264 & 0.191 & 5,332 & 0.190 & 0.001 & 0.2 \\
\hline
\end{tabular}

Continued 


\section{Table 2 Continued}

Panel C: Means and Counts of Variables By Rev and MF

\begin{tabular}{lcccc} 
& $\mathrm{Rev}=1 \mathrm{MF}=1$ & \multicolumn{2}{c}{$\operatorname{Rev}=1 \mathrm{MF}=0$} \\
Variable & $\mathbf{N}$ & $\mathrm{Mean}$ & $\mathbf{N}$ & $\mathrm{Mean}$ \\
\hline Capex & 2,835 & 3.584 & 552 & 3.756 \\
WC & 2,835 & 1.121 & 552 & 0.726 \\
WC_Assets & 2,835 & 2.812 & 552 & 2.058 \\
Expected_Firm_Volatility & 2,835 & 0.033 & 552 & 0.032 \\
Supplier Controls & & & & 0.062 \\
CFO & 2,835 & 0.052 & 552 & 2,349 \\
Size & 2,835 & 4,823 & 552 & 2.771 \\
MTB & 2,835 & 3.375 & 552 & 0.382 \\
Lev & 2,835 & 0.421 & 552 & 2.807 \\
Customer Controls & & & & -0.013 \\
Cust_MTB & 2,835 & 3.311 & 552 & 36,708 \\
Cust_Analyst_Accuracy & 2,835 & -0.009 & 552 & 0.013 \\
Cust_Size & 2,835 & 46,049 & 552 & 0.194 \\
Cust_STD_ROA & 2,835 & 0.010 & 552 & \\
Sale_PCT & 2,724 & 0.193 & 540 & \\
\hline
\end{tabular}

\begin{tabular}{lcccc} 
& \multicolumn{3}{c}{$\mathrm{Rev}=0 \mathrm{MF}=1$} & \multicolumn{2}{c}{$\mathrm{Rev}=0 \mathrm{MF}=0$} \\
Variable & $\mathbf{N}$ & $\mathrm{Mean}$ & $\mathbf{N}$ & $\mathrm{Mean}$ \\
\hline Capex & 3,221 & 4.143 & 2,157 & 6.769 \\
WC & 3,221 & 0.152 & 2,157 & 0.337 \\
WC_Assets & 3,221 & 1.452 & 2,157 & 1.727 \\
Expected_Firm_Volatility & 3,221 & 0.037 & 2,157 & 0.038 \\
Supplier Controls & & & & \\
CFO & 3,221 & 0.083 & 2,157 & 0.073 \\
Size & 3,221 & 4,353 & 2,157 & 2,474 \\
MTB & 3,221 & 3.116 & 2,157 & 2.825 \\
Lev & 3,221 & 0.460 & 2,157 & 0.407 \\
Customer Controls & & & & \\
Cust_MTB & 3,221 & 3.999 & 2,157 & 3.715 \\
Cust_Analyst_Accuracy & 3,221 & -0.009 & 2,157 & -0.017 \\
Cust_Size & 3,221 & 73,443 & 2,157 & 31,134 \\
Cust_STD_ROA & 3,221 & 0.009 & 2,157 & 0.018 \\
Sale_PCT & 3,190 & 0.194 & 2,142 & 0.186 \\
\hline
\end{tabular}

\section{Continued}


Table 2 Continued

Panel D: Description of Customers' Forecasting Accuracy Compared to I/B/E/S Population

\begin{tabular}{lcccccc} 
Variable & $\mathbf{N}$ & mean & $\mathbf{p 5 0}$ & $\mathbf{p 2 5}$ & $\mathbf{p 7 5}$ & sd \\
\hline Rev_Accuracy & 3,380 & -0.126 & -0.031 & -0.094 & -0.011 & 0.308 \\
Population Rev Accuracy & 13,126 & -0.087 & -0.030 & -0.082 & -0.011 & 0.173 \\
Earn_Accuracy & 6,056 & -0.007 & -0.003 & -0.007 & -0.001 & 0.011 \\
Population Earn Accuracy & 16,281 & -0.017 & -0.006 & -0.016 & -0.003 & 0.031 \\
\hline
\end{tabular}

Panel D: Univariate Correlation

\begin{tabular}{|c|c|c|c|c|c|c|c|c|c|c|}
\hline & Variable & 1) & 2) & 3) & 4) & 6) & 7) & 8) & 9) & 10) \\
\hline 1) & $W C$ & 1.000 & & & & & & & & \\
\hline 2) & WC_Assets & 0.717 & 1.000 & & & & & & & \\
\hline 3) & Capex & 0.074 & 0.136 & 1.000 & & & & & & \\
\hline 4) & Expected_Firm_Volatility & -0.097 & -0.129 & -0.061 & 1.000 & & & & & \\
\hline 5) & $R E V$ & 0.055 & 0.058 & -0.133 & -0.112 & 1.000 & & & & \\
\hline 6) & $M F$ & 0.012 & 0.014 & -0.182 & -0.047 & 0.251 & 1.000 & & & \\
\hline 7) & Earn_accuracy & 0.005 & 0.009 & -0.080 & -0.046 & 0.081 & . & 1.000 & & \\
\hline 8) & Size & 0.009 & 0.028 & 0.071 & -0.498 & 0.016 & 0.020 & 0.031 & 1.000 & \\
\hline 9) & $M T B$ & 0.100 & 0.138 & 0.044 & -0.053 & 0.039 & 0.056 & 0.085 & 0.231 & 1.000 \\
\hline 10) & Lev & -0.007 & -0.056 & 0.044 & -0.086 & -0.053 & 0.084 & -0.062 & 0.275 & 0.243 \\
\hline 11) & $C F O$ & 0.113 & 0.089 & 0.171 & -0.335 & -0.072 & -0.006 & $-\mathbf{0 . 0 3 9}$ & 0.312 & -0.113 \\
\hline 12) & Cust_Analyst_Accuracy & 0.033 & 0.038 & -0.150 & -0.061 & 0.081 & 0.186 & 0.606 & 0.026 & 0.041 \\
\hline 13) & Cust_STD_Roa & -0.048 & -0.048 & 0.054 & 0.184 & -0.067 & -0.207 & -0.185 & -0.112 & -0.024 \\
\hline 14) & Cust_Size & -0.014 & -0.038 & 0.011 & -0.121 & -0.046 & 0.166 & 0.084 & 0.156 & -0.043 \\
\hline 15) & Cust_MTB & -0.009 & 0.002 & -0.023 & 0.052 & -0.108 & 0.023 & 0.134 & -0.023 & 0.047 \\
\hline 16) & Recession & -0.123 & $-\mathbf{0 . 1 7 0}$ & -0.001 & 0.302 & -0.089 & -0.016 & 0.017 & -0.052 & $-\mathbf{0 . 0 3 0}$ \\
\hline 17) & Default_Spread & -0.061 & $-\mathbf{0 . 1 1 0}$ & -0.055 & 0.152 & 0.005 & 0.005 & 0.017 & -0.025 & -0.076 \\
\hline \multirow[t]{2}{*}{ 18) } & Interest_Rate & -0.025 & -0.008 & 0.035 & 0.048 & -0.177 & $\mathbf{0 . 0 2 7}$ & $-\mathbf{0 . 0 3 7}$ & -0.061 & 0.071 \\
\hline & & 11) & 12) & 13) & 14) & 15) & 16) & 17) & 18) & \\
\hline 12) & Cust_Analyst_Accuracy & -0.004 & 1.000 & & & & & & & \\
\hline 13) & Cust_STD_Roa & -0.107 & -0.345 & 1.000 & & & & & & \\
\hline 14) & Cust_Size & 0.094 & 0.202 & -0.316 & 1.000 & & & & & \\
\hline 15) & Cust_MTB & -0.051 & 0.143 & -0.033 & 0.193 & 1.000 & & & & \\
\hline 16) & Recession & 0.006 & -0.025 & 0.056 & 0.001 & 0.080 & 1.000 & & & \\
\hline 17) & Default_Spread & 0.022 & -0.040 & 0.071 & -0.017 & -0.051 & 0.419 & 1.000 & & \\
\hline 18) & Interest_Rate & -0.035 & -0.004 & -0.053 & -0.016 & 0.137 & 0.119 & -0.293 & 1.000 & \\
\hline
\end{tabular}


Table 3: The Relationship Between Investment and a Firm's Expected Volatility

This table displays the results of estimating equation (1) within several samples. Panel A displays the results for estimating the relation between expected volatility and both capital investment and working capital investment within my sample of suppliers. Panel B displays the estimation of equation (1) within the Compustat universe during the same time period as my sample (2001-2016). Panel C displays results of the estimation for the period from 1964-2000, which is equivalent to the sample from Arif et al. (2016) that excludes my time period. All continuous variables are winsorized at 1 and 99 percent and standardized to have zero mean and a standard deviation of $1 . *, * *$, and *** represent significance at the $.1, .05$, and .01 levels using a two-tailed test. Standard errors are clustered at the customer and supplier levels.

Panel A: The relationship between volatility and investment for suppliers

\begin{tabular}{lccc} 
Dependent Variable: & Capex & WC & WC Assets \\
\hline & Coeff & Coeff & Coeff \\
& T-Stat & T-Stat & T-Stat \\
\hline \hline Uncertainty & & & \\
Expected Firm Volatility & 0.00475 & $-0.440^{* *}$ & $-0.775^{* * *}$ \\
Supplier Controls & $(0.0444)$ & $(-2.477)$ & $(-2.912)$ \\
Size & & & \\
& 0.109 & $-0.710^{* * *}$ & $-0.681^{* * *}$ \\
MTB & $(0.896)$ & $(-5.393)$ & $(-3.653)$ \\
& $0.224^{* * *}$ & $0.292^{* * *}$ & $0.490^{* * * *}$ \\
Leverage & $(6.312)$ & $(5.194)$ & $(7.124)$ \\
& $-0.856^{* * *}$ & -0.195 & $-0.900^{* * *}$ \\
CFO & $(-8.289)$ & $(-1.436)$ & $(-4.800)$ \\
& $0.387 * * *$ & $1.053^{* * *}$ & $1.068^{* * * *}$ \\
Capital Intensity & $(4.142)$ & $(7.135)$ & $(6.356)$ \\
& $3.817^{* * *}$ & -0.0876 & -0.00876 \\
Macro & $(14.22)$ & $(-0.734)$ & $(-0.0647)$ \\
Recession & & & \\
& 0.207 & $-1.699 * * *$ & $-2.810^{* * *}$ \\
Default_Spread & $(1.284)$ & $(-4.991)$ & $(-6.582)$ \\
Interest_Rate & $-0.197^{* * *}$ & -0.110 & $-0.402^{* * *}$ \\
& $(-2.849)$ & $(-0.959)$ & $(-2.722)$ \\
Observations & 0.140 & $-0.197 *$ & -0.170 \\
R-squared & $(1.621)$ & $(-1.678)$ & $(-0.982)$ \\
& & & \\
& 8,765 & 8,765 & 8,765 \\
& 0.430 & 0.048 & 0.074 \\
\hline
\end{tabular}

Continued 


\section{Table 3 Continued}

Panel B: The relationship between volatility and investment for all firms 2001-2016

\begin{tabular}{|c|c|c|c|}
\hline Dependent Variable: & Capex & WC & WC Assets \\
\hline & Coeff & Coeff & Coeff \\
\hline & T-Stat & T-Stat & T-Stat \\
\hline \multicolumn{4}{|l|}{ Uncertainty } \\
\hline \multirow[t]{2}{*}{ Expected Firm Volatility } & 0.0503 & $-0.413 * * *$ & $-0.776^{* * *}$ \\
\hline & $(1.091)$ & $(-7.130)$ & $(-11.47)$ \\
\hline \multicolumn{4}{|l|}{ Supplier Controls } \\
\hline \multirow[t]{2}{*}{ Size } & 0.0665 & $-0.256 * * *$ & $-0.360 * * *$ \\
\hline & (1.076) & $(-5.426)$ & $(-5.743)$ \\
\hline \multirow[t]{2}{*}{$M T B$} & $0.249 * * *$ & $0.0725 * * *$ & $0.279 * * *$ \\
\hline & $(18.91)$ & $(5.543)$ & $(17.22)$ \\
\hline \multirow[t]{2}{*}{ Leverage } & $-1.011 * * *$ & $-0.134 * * *$ & $-0.721 * * *$ \\
\hline & $(-19.89)$ & $(-3.053)$ & $(-12.70)$ \\
\hline \multirow[t]{2}{*}{$C F O$} & $0.632 * * *$ & $0.609 * * *$ & $0.541 * * *$ \\
\hline & (12.49) & $(10.25)$ & $(8.769)$ \\
\hline \multirow[t]{2}{*}{ Capital Intensity } & $3.906 * * *$ & $-0.0882 * *$ & $-0.129 * * *$ \\
\hline & $(36.55)$ & $(-2.519)$ & $(-2.934)$ \\
\hline \multicolumn{4}{|l|}{ Macro } \\
\hline \multirow[t]{2}{*}{ Recession } & -0.0460 & $-1.224 * * *$ & $-2.549 * * *$ \\
\hline & $(-0.664)$ & $(-11.39)$ & $(-19.70)$ \\
\hline \multirow[t]{2}{*}{ Default_Spread } & $-0.179 * * *$ & $-0.131 * * *$ & $-0.295 * * *$ \\
\hline & $(-7.415)$ & $(-3.172)$ & $(-6.217)$ \\
\hline \multirow[t]{2}{*}{ Interest_Rate } & $0.383 * * *$ & $0.111 * * *$ & $0.368 * * *$ \\
\hline & $(10.56)$ & $(2.921)$ & $(7.466)$ \\
\hline Observations & 41,930 & 41,930 & 41,930 \\
\hline R-squared & 0.367 & 0.020 & 0.054 \\
\hline
\end{tabular}

Continued 


\section{Table 3 continued}

Panel C: The relationship between volatility and investment for all firms 1964-2000

\begin{tabular}{|c|c|c|c|}
\hline Dependent Variable: & Capex & WC & WC Assets \\
\hline & $\begin{array}{l}\text { Coeff } \\
\text { T-Stat } \\
\end{array}$ & $\begin{array}{l}\text { Coeff } \\
\text { T-Stat } \\
\end{array}$ & $\begin{array}{l}\text { Coeff } \\
\text { T-Stat } \\
\end{array}$ \\
\hline \multicolumn{4}{|l|}{ Uncertainty } \\
\hline Expected Firm Volatility & $\begin{array}{c}-0.218 * * * \\
(-4.865)\end{array}$ & $\begin{array}{c}-0.933 * * * \\
(-15.95)\end{array}$ & $\begin{array}{c}-1.145^{* * *} \\
(-14.94)\end{array}$ \\
\hline \multicolumn{4}{|l|}{ Supplier Controls } \\
\hline Size & $\begin{array}{l}-0.103 * \\
(-1.747)\end{array}$ & $\begin{array}{c}-0.881 * * * \\
(-17.24)\end{array}$ & $\begin{array}{c}-0.857 * * * \\
(-12.29)\end{array}$ \\
\hline$M T B$ & $\begin{array}{c}1.715^{* * * *} \\
(28.56)\end{array}$ & $\begin{array}{c}1.094 * * * \\
(16.40)\end{array}$ & $\begin{array}{c}2.118 * * * \\
(23.59)\end{array}$ \\
\hline Leverage & $\begin{array}{c}-1.021 * * * \\
(-21.14)\end{array}$ & $\begin{array}{c}-0.395^{* * *} \\
(-7.998)\end{array}$ & $\begin{array}{c}-0.971 * * * \\
(-14.32)\end{array}$ \\
\hline$C F O$ & $\begin{array}{c}3.895 * * * \\
(51.56)\end{array}$ & $\begin{array}{c}-0.816^{* * *} \\
(-19.18)\end{array}$ & $\begin{array}{c}-1.266^{* * *} \\
(-21.96)\end{array}$ \\
\hline Capital Intensity & $\begin{array}{c}0.900 * * * \\
(18.34)\end{array}$ & $\begin{array}{c}1.245 * * * \\
(19.94)\end{array}$ & $\begin{array}{c}1.133 * * * \\
(14.06)\end{array}$ \\
\hline Macro & & & \\
\hline Recession & $\begin{array}{c}-0.449 * * * \\
(-5.599)\end{array}$ & $\begin{array}{c}-0.894 * * * \\
(-8.519)\end{array}$ & $\begin{array}{c}-1.619 * * * \\
(-11.65)\end{array}$ \\
\hline Default_Spread & $\begin{array}{c}-0.287 * * * \\
(-7.576)\end{array}$ & $\begin{array}{c}-0.803^{* * *} \\
(-16.63)\end{array}$ & $\begin{array}{c}-1.210 * * * \\
(-18.89)\end{array}$ \\
\hline Interest_Rate & $\begin{array}{c}0.637 * * * \\
(18.31)\end{array}$ & $\begin{array}{c}0.559 * * * \\
(11.87)\end{array}$ & $\begin{array}{c}0.795^{* * *} \\
(13.15)\end{array}$ \\
\hline $\begin{array}{l}\text { Observations } \\
\text { R-squared }\end{array}$ & $\begin{array}{c}74,563 \\
0.249 \\
\end{array}$ & $\begin{array}{c}74,563 \\
0.036\end{array}$ & $\begin{array}{c}74,563 \\
0.052\end{array}$ \\
\hline
\end{tabular}


Table 4: The Relationship Between CIQ, Uncertainty, and Investment

This table shows the set of tests for H1a, H1b, and H1c. Panel A shows estimates of equation (2) with Rev as a measure for CIQ in column 1 and MF in column 2. Panel B shows estimates of equation (3) using WC as investments. Rev is used as the measure of CIQ in columns 1 and 2 and MF is used in columns 3 and 4. Panel C replicates panel B using WC Assets as the dependent variable. All continuous dependent variables are winsorized at 1 and 99 percent and standardized to have zero mean and a standard deviation of $1 . *, * *$, and $* * *$ represent significance at the $.1, .05$, and .01 levels using a two-tailed test. Standard errors are clustered at the customer and supplier levels.

Panel A: The Effect of CIQ on Expected Volatility

Dependent Variable:

Exp. Vol.

Exp. Vol.

Coeff

Coeff

T-Stat

T-Stat

\begin{tabular}{l}
\hline Customer Information \\
$R E V$ \\
$M F$ \\
Supplier Controls \\
Size \\
MTB \\
Leverage \\
CFO \\
Capital Intensity \\
Customer Controls \\
Cust_Analyst_Accuracy \\
Cust_STD_ROA \\
Cust_Size \\
Recession
\end{tabular}

$-0.213 * * *$

$(-5.883)$

-0.417 ***

$(-17.95)$

0.0147

(0.991)

$0.0743 * * *$

(3.550)

$-0.186 * * *$

(-10.04)

0.0245

(0.981)

$-0.00292$

(-0.164)

$0.0772 * * *$

(4.181)

$-0.00751$

$(-0.328)$

0.0129

(0.654)

$0.606 * * *$

(14.27)
0.000963

(0.0257)

$-0.419 * * *$

(-17.99)

0.0138

(0.924)

$0.0758 * * *$

(3.554)

$-0.182 * * *$

$(-9.782)$

0.0341

(1.310)

$-0.00810$

(-0.476)

$0.0846 * * *$

(4.689)

$-0.00362$

$(-0.177)$

0.0226

(1.073)

$0.615 * * *$

(13.81)

Continued 


\section{Table 4 continued}

Dependent Variable:

Exp. Vol.

Exp. Vol.

\begin{tabular}{lcc}
\hline & Coeff & Coeff \\
& T-Stat & T-Stat \\
\hline \hline Default_Spread & 0.0267 & $0.0294^{*}$ \\
& $(1.622)$ & $(1.949)$ \\
Interest_Rate & $-0.0259 * *$ & -0.00778 \\
& $(-2.363)$ & $(-0.729)$ \\
Observations & & 8,764 \\
R-squared & 8,764 & 0.403 \\
Fixed Effects & 0.412 & Industry \\
\hline
\end{tabular}

Continued 
Table 4 continued

\begin{tabular}{|c|c|c|c|c|c|}
\hline Dependent Variable: & WC & WC & WC & WC & Diff. \\
\hline & Coeff & Coeff & Coeff & Coeff & Diff. \\
\hline & T-Stat & T-Stat & T-Stat & T-Stat & $P\left(\chi^{2}\right)$ \\
\hline \multicolumn{6}{|l|}{ CIQ and Uncertainty } \\
\hline \multirow[t]{2}{*}{ REV } & $0.676 * * *$ & $0.615 * * *$ & & & 0.061 \\
\hline & $(2.924)$ & $(2.818)$ & & & 0.12 \\
\hline \multirow[t]{2}{*}{$M F$} & & & -0.150 & -0.149 & -0.001 \\
\hline & & & $(-0.812)$ & $(-0.821)$ & 0.99 \\
\hline \multirow[t]{2}{*}{ Expected_Volatility } & & $-0.283 *$ & & $-0.329 *$ & \\
\hline & & $(-1.707)$ & & $(-1.924)$ & \\
\hline \multicolumn{6}{|l|}{ Supplier Controls } \\
\hline \multirow[t]{2}{*}{ Size } & $-0.611 * * *$ & $-0.729 * * *$ & $-0.608 * * *$ & $-0.746 * * *$ & \\
\hline & $(-4.930)$ & $(-4.995)$ & $(-4.897)$ & $(-5.083)$ & \\
\hline \multirow[t]{2}{*}{$M T B$} & $1.052 * * *$ & $1.056 * * *$ & $1.056 * * *$ & $1.060 * * *$ & \\
\hline & $(5.274)$ & $(5.292)$ & $(5.350)$ & $(5.361)$ & \\
\hline \multirow[t]{2}{*}{ Leverage } & $-0.341 * *$ & $-0.320 * *$ & $-0.342 * *$ & $-0.317 * *$ & \\
\hline & $(-2.222)$ & $(-2.078)$ & $(-2.219)$ & $(-2.052)$ & \\
\hline \multirow[t]{2}{*}{$\mathrm{CFO}$} & $1.114 * * *$ & $1.061 * * *$ & $1.101 * * *$ & $1.041 * * *$ & \\
\hline & $(7.861)$ & (7.173) & $(7.843)$ & (7.054) & \\
\hline \multirow[t]{2}{*}{ Capital Intensity } & -0.141 & -0.134 & -0.172 & -0.161 & \\
\hline & $(-0.789)$ & $(-0.747)$ & $(-0.988)$ & $(-0.917)$ & \\
\hline \multicolumn{6}{|l|}{ Customer Controls } \\
\hline \multirow[t]{2}{*}{ Cust_Analyst_Accuracy } & 0.165 & 0.164 & $0.186^{*}$ & $0.183 *$ & \\
\hline & $(1.591)$ & $(1.605)$ & $(1.840)$ & $(1.836)$ & \\
\hline \multirow[t]{2}{*}{ Cust_STD_ROA } & -0.161 & -0.139 & -0.190 & -0.162 & \\
\hline & $(-1.241)$ & $(-1.095)$ & $(-1.428)$ & $(-1.254)$ & \\
\hline \multirow[t]{2}{*}{ Cust_Size } & $-0.184 *$ & $-0.186^{*}$ & $-0.187 *$ & $-0.188 *$ & \\
\hline & $(-1.935)$ & $(-1.951)$ & $(-1.840)$ & $(-1.848)$ & \\
\hline \multirow[t]{2}{*}{ Cust_MTB } & 0.0695 & 0.0732 & 0.0354 & 0.0428 & \\
\hline & $(0.845)$ & $(0.896)$ & $(0.380)$ & $(0.469)$ & \\
\hline \multicolumn{6}{|l|}{ Macro } \\
\hline \multirow[t]{2}{*}{ Recession } & $-1.930 * * *$ & $-1.759 * * *$ & $-1.963 * * *$ & $-1.760 * * *$ & \\
\hline & $(-6.010)$ & $(-5.329)$ & $(-6.168)$ & $(-5.330)$ & \\
\hline \multirow[t]{2}{*}{ Default_Spread } & -0.0886 & -0.0810 & -0.0948 & -0.0851 & \\
\hline & $(-0.732)$ & $(-0.672)$ & $(-0.781)$ & $(-0.702)$ & \\
\hline \multirow[t]{2}{*}{ Interest_Rate } & -0.135 & -0.143 & -0.191 & -0.193 & \\
\hline & $(-1.155)$ & $(-1.208)$ & $(-1.634)$ & $(-1.647)$ & \\
\hline Observations & 8,764 & 8,764 & 8,764 & 8,764 & \\
\hline R-squared & 0.063 & 0.063 & 0.061 & 0.062 & \\
\hline Fixed Effects & Industry & Industry & Industry & Industry & \\
\hline
\end{tabular}

Continued 
Table 4 continued

Panel C: The Effect of CIQ on Investment Using WC Assets

\begin{tabular}{|c|c|c|c|c|c|}
\hline Dependent Variable: & WC Assets & WC Assets & WC Assets & WC Assets & Diff. \\
\hline & Coeff & Coeff & Coeff & Coeff & Diff. \\
\hline & T-Stat & T-Stat & $T$-Stat & T-Stat & $P\left(\chi^{2}\right)$ \\
\hline \multicolumn{6}{|l|}{ CIQ and Uncertainty } \\
\hline \multirow[t]{2}{*}{$R E V$} & $0.821 * * *$ & $0.691 * * *$ & & & $0.13 * *$ \\
\hline & (3.536) & $(2.956)$ & & & 0.02 \\
\hline \multirow[t]{2}{*}{$M F$} & & & -0.0614 & -0.0608 & -0.0006 \\
\hline & & & $(-0.202)$ & $(-0.202)$ & 0.98 \\
\hline \multirow[t]{2}{*}{ Expected_Volatility } & & $-0.609 * *$ & & $-0.660 * *$ & \\
\hline & & $(-2.457)$ & & $(-2.526)$ & \\
\hline \multicolumn{6}{|l|}{ Supplier Controls } \\
\hline \multirow[t]{2}{*}{ Size } & $-0.423 * *$ & $-0.677 * * *$ & $-0.416^{* *}$ & $-0.693 * * *$ & \\
\hline & $(-2.359)$ & $(-3.288)$ & $(-2.116)$ & $(-3.361)$ & \\
\hline \multirow[t]{2}{*}{$M T B$} & $1.724 * * *$ & $1.733 * * *$ & $1.728 * * *$ & $1.738 * * *$ & \\
\hline & $(8.901)$ & $(8.864)$ & $(7.553)$ & $(7.594)$ & \\
\hline \multirow[t]{2}{*}{ Leverage } & $-1.176 * * *$ & $-1.131 * * *$ & $-1.181 * * *$ & $-1.131 * * *$ & \\
\hline & $(-6.713)$ & $(-6.462)$ & $(-6.035)$ & $(-5.644)$ & \\
\hline \multirow[t]{2}{*}{$C F O$} & $1.166 * * *$ & $1.052 * * *$ & $1.150 * * *$ & $1.030 * * *$ & \\
\hline & $(6.454)$ & $(5.440)$ & $(6.809)$ & $(5.668)$ & \\
\hline \multirow[t]{2}{*}{ Capital Intensity } & 0.107 & 0.122 & 0.0700 & 0.0925 & \\
\hline & $(0.553)$ & $(0.626)$ & $(0.358)$ & $(0.468)$ & \\
\hline \multicolumn{6}{|l|}{ Customer Controls } \\
\hline \multirow[t]{2}{*}{ Cust_Analyst_Accuracy } & $0.247 * *$ & $0.245 * *$ & $0.269^{*}$ & $0.263 *$ & \\
\hline & $(2.030)$ & $(2.018)$ & (1.928) & (1.899) & \\
\hline \multirow[t]{2}{*}{ Cust_STD_ROA } & $-0.261 * *$ & $-0.214^{*}$ & -0.291 & -0.236 & \\
\hline & $(-2.006)$ & $(-1.647)$ & $(-1.466)$ & $(-1.212)$ & \\
\hline \multirow[t]{2}{*}{ Cust_Size } & $-0.435 * * *$ & $-0.440 * * *$ & $-0.447 * * *$ & $-0.449 * * *$ & \\
\hline & $(-3.641)$ & $(-3.685)$ & $(-3.021)$ & $(-3.020)$ & \\
\hline \multirow[t]{2}{*}{ Cust_MTB } & $0.196^{*}$ & $0.204 *$ & 0.157 & 0.172 & \\
\hline & $(1.742)$ & $(1.817)$ & $(1.040)$ & $(1.183)$ & \\
\hline \multicolumn{6}{|l|}{ Macro } \\
\hline \multirow[t]{2}{*}{ Recession } & $-3.235 * * *$ & $-2.866^{* * *}$ & $-3.271 * * *$ & $-2.865 * * *$ & \\
\hline & $(-8.627)$ & $(-7.101)$ & $(-7.615)$ & $(-6.671)$ & \\
\hline \multirow[t]{2}{*}{ Default_Spread } & $-0.376 * *$ & $-0.359 * *$ & $-0.385 * *$ & $-0.366^{* *}$ & \\
\hline & $(-2.292)$ & $(-2.192)$ & $(-2.474)$ & $(-2.352)$ & \\
\hline \multirow[t]{2}{*}{ Interest_Rate } & -0.123 & -0.139 & -0.192 & -0.197 & \\
\hline & $(-0.833)$ & $(-0.931)$ & $(-1.124)$ & $(-1.150)$ & \\
\hline Observations & 8,764 & 8,764 & 8,764 & 8,764 & \\
\hline R-squared & 0.09 & 0.093 & 0.088 & 0.091 & \\
\hline Fixed Effects & Industry & Industry & Industry & Industry & \\
\hline
\end{tabular}


Table 5: The Effect of Customer Information Quality on the Volatility-Investment Relationship

This table shows the tests for $\mathrm{H} 2$. This shows estimates of equation (4) using $\mathrm{WC}$ as investments in columns 1 and 3 and WC Assets in columns 2 and 4. Rev is used as the measure of CIQ in columns 1 and 2 and MF is used in columns 3 and 4. All continuous variables are winsorized at 1 and 99 percent and standardized to have zero mean and a standard deviation of $1 . *, * *$, and $* * *$ represent significance at the $.1, .05$, and .01 levels using a two-tailed test. Standard errors are clustered at the customer and supplier levels.

\begin{tabular}{|c|c|c|c|c|}
\hline Dependent Variable: & WC & WC Assets & WC & WC Assets \\
\hline & Coeff & Coeff & Coeff & Coeff \\
\hline & $T$-Stat & $T$-Stat & $T$-Stat & T-Stat \\
\hline \multicolumn{5}{|l|}{ "CIQ and Uncertainty } \\
\hline $\operatorname{Rev}$ & $\begin{array}{c}0.656 * * * \\
(3.095)\end{array}$ & $\begin{array}{c}0.819 * * * \\
(2.846)\end{array}$ & & \\
\hline$M F$ & & & $\begin{array}{c}-0.146 \\
(-0.809)\end{array}$ & $\begin{array}{l}-0.0688 \\
(-0.230)\end{array}$ \\
\hline Expected Volatility & $\begin{array}{l}-0.374 * * \\
(-2.190)\end{array}$ & $\begin{array}{c}-0.963 * * * \\
(-4.133)\end{array}$ & $\begin{array}{c}-0.263 \\
(-1.220)\end{array}$ & $\begin{array}{c}-0.735^{* * *} \\
(-2.666)\end{array}$ \\
\hline Rev*Expected Volatility & $\begin{array}{l}0.421 * \\
(1.778)\end{array}$ & $\begin{array}{c}1.436 * * * \\
(3.660)\end{array}$ & & \\
\hline$M F^{*}$ Expected Volatility & & & $\begin{array}{l}-0.0756 \\
(-0.359)\end{array}$ & $\begin{array}{c}0.116 \\
(0.374)\end{array}$ \\
\hline \multicolumn{5}{|l|}{ Supplier Controls } \\
\hline Size & $\begin{array}{c}-0.699 * * * \\
(-4.753)\end{array}$ & $\begin{array}{c}-0.597 * * * \\
(-2.961)\end{array}$ & $\begin{array}{c}-0.741 * * * \\
(-5.017)\end{array}$ & $\begin{array}{c}-0.688 * * * \\
(-3.331)\end{array}$ \\
\hline$M T B$ & $\begin{array}{c}1.049 * * * \\
(5.275)\end{array}$ & $\begin{array}{c}1.713 * * * \\
(7.510)\end{array}$ & $\begin{array}{c}1.059 * * * \\
(5.362)\end{array}$ & $\begin{array}{c}1.739 * * * \\
(7.579)\end{array}$ \\
\hline Leverage & $\begin{array}{c}-0.316^{* *} \\
(-2.059)\end{array}$ & $\begin{array}{c}-1.134 * * * \\
(-5.713)\end{array}$ & $\begin{array}{c}-0.313 * * \\
(-2.024)\end{array}$ & $\begin{array}{c}-1.128 * * * \\
(-5.656)\end{array}$ \\
\hline CFO & $\begin{array}{c}1.080 * * * \\
(7.219)\end{array}$ & $\begin{array}{c}1.099 * * * \\
(5.985)\end{array}$ & $\begin{array}{c}1.047 * * * \\
(7.104)\end{array}$ & $\begin{array}{c}1.032 * * * \\
(5.651)\end{array}$ \\
\hline Capital Intensity & $\begin{array}{c}-0.149 \\
(-0.829)\end{array}$ & $\begin{array}{l}0.0958 \\
(0.474)\end{array}$ & $\begin{array}{c}-0.168 \\
(-0.960)\end{array}$ & $\begin{array}{l}0.0872 \\
(0.441)\end{array}$ \\
\hline \multicolumn{5}{|l|}{ Customer Controls } \\
\hline Cust_Analyst_Accuracy & $\begin{array}{c}0.129 \\
(1.360)\end{array}$ & $\begin{array}{l}0.239 * \\
(1.864)\end{array}$ & $\begin{array}{c}0.146 \\
(1.583)\end{array}$ & $\begin{array}{l}0.253 * \\
(1.909)\end{array}$ \\
\hline Cust_Analyst_Accuracy*Volatility & $\begin{array}{c}0.160 \\
(1.386)\end{array}$ & $\begin{array}{l}0.0277 \\
(0.197)\end{array}$ & $\begin{array}{c}0.172 \\
(1.552)\end{array}$ & $\begin{array}{l}0.0413 \\
(0.283)\end{array}$ \\
\hline Cust_STD_ROA & $\begin{array}{c}-0.127 \\
(-1.028)\end{array}$ & $\begin{array}{c}-0.202 \\
(-1.100)\end{array}$ & $\begin{array}{c}-0.155 \\
(-1.212)\end{array}$ & $\begin{array}{c}-0.230 \\
(-1.184)\end{array}$ \\
\hline Cust_Size & $\begin{array}{l}-0.200 * * \\
(-2.130)\end{array}$ & $\begin{array}{c}-0.465 * * * \\
(-3.283)\end{array}$ & $\begin{array}{l}-0.196 * \\
(-1.939)\end{array}$ & $\begin{array}{c}-0.452 * * * \\
(-3.065)\end{array}$ \\
\hline Cust_MTB & $\begin{array}{l}0.0811 \\
(0.958)\end{array}$ & $\begin{array}{l}0.245^{*} \\
(1.774)\end{array}$ & $\begin{array}{l}0.0366 \\
(0.401)\end{array}$ & $\begin{array}{c}0.172 \\
(1.191) \\
\text { Continued }\end{array}$ \\
\hline
\end{tabular}




\section{Table 5 continued}

\begin{tabular}{|c|c|c|c|c|}
\hline Dependent Variable: & WC & WC Assets & WC & WC Assets \\
\hline & Coeff & Coeff & Coeff & Coeff \\
\hline & T-Stat & T-Stat & $T$-Stat & T-Stat \\
\hline \multicolumn{5}{|l|}{ Macro } \\
\hline \multirow[t]{2}{*}{ Recession } & $-1.726 * * *$ & $-2.762 * * *$ & $-1.758 * * *$ & $-2.864 * * *$ \\
\hline & $(-5.258)$ & $(-6.399)$ & $(-5.311)$ & $(-6.655)$ \\
\hline \multirow[t]{2}{*}{ Default_Spread } & -0.119 & $-0.468 * * *$ & -0.0929 & $-0.366 * *$ \\
\hline & $(-1.032)$ & $(-3.090)$ & $(-0.767)$ & $(-2.358)$ \\
\hline \multirow[t]{2}{*}{ Interest_Rate } & -0.148 & -0.151 & $-0.197 *$ & -0.197 \\
\hline & $(-1.265)$ & $(-0.882)$ & $(-1.667)$ & $(-1.151)$ \\
\hline $\operatorname{Prob}\left(\right.$ Volatility $+C I Q^{*}$ Volatility $\left.=0\right)$ & 0.851 & 0.283 & 0.072 & 0.045 \\
\hline Observations & 8,764 & 8,764 & 8,764 & 8,764 \\
\hline R-squared & 0.065 & 0.097 & 0.063 & 0.091 \\
\hline Fixed Effects & Industry & Industry & Industry & Industry \\
\hline
\end{tabular}




\section{Table 6: Cross-Sectional Tests with More Important Relationships}

Table 6 shows cross-sectional tests for H3 and H4. I split the observations into two subsamples - the important customer subsample with above median Sale_Pct and the unimportant customer subsample with below median Sale_Pct (supplier's sales to the customer as a percentage of total sales). Panel A shows estimates of equation (2) in both subsamples and tests for a difference in the CIQ proxy between the groups. Panel B shows estimates of equation (3) across the subsamples using WC as the investment proxy, while panel $\mathrm{C}$ does the same with WC Assets. Panel D shows estimates of equation (4) between the different sample with tests of differences in the interaction term. Estimates for the important customer subsample are shown on the top of the panel with estimates in the unimportant customer subsample in the middle and a test of differences at the bottom of the panel. Panels E, F, G, and H further divide the sample based on supplier importance (the percentage of the customer's cost of goods sold that come from the supplier's sales) and examines the important $C \& S$ subsample, where both the customer and supplier are above median importance, and the unimportant $C \& S$ subsample where both are less important. Panels E, F, G, and H repeat analysis from A, B, C, and D respectively. All continuous variables are winsorized at 1 and 99 percent and standardized to have zero mean and a standard deviation of $1 . *, * *$, and *** represent significance at the $.1, .05$, and .01 levels using a two-tailed test. Standard errors are clustered at the customer and supplier levels.

Panel A: The Effect of CIQ on Expected Volatility

\begin{tabular}{|c|c|c|c|c|c|c|}
\hline Dependent Variable: & Exp. Vol. & Exp. Vol. & Exp. Vol. & Exp. Vol. & & \\
\hline & $\begin{array}{c}\text { important } \\
\text { cust }\end{array}$ & $\begin{array}{c}\text { unimportant } \\
\text { cust }\end{array}$ & $\begin{array}{c}\text { important } \\
\text { cust }\end{array}$ & $\begin{array}{c}\text { unimportant } \\
\text { cust }\end{array}$ & $\begin{array}{l}\text { imp - } \\
\text { unimp }\end{array}$ & $\mathrm{P}\left(\chi^{2}\right)$ \\
\hline & Coeff & Coeff & Coeff & Coeff & & \\
\hline & $T$-Stat & $T$-Stat & $T$-Stat & $T$-Stat & & \\
\hline \multicolumn{7}{|l|}{ CIQ } \\
\hline$R E V$ & $\begin{array}{c}-0.193 * * * \\
(-5.871)\end{array}$ & $\begin{array}{c}-0.241 * * * \\
(-7.042)\end{array}$ & & & 0.048 & 0.29 \\
\hline$M F$ & & & $\begin{array}{l}0.0330 \\
(0.814)\end{array}$ & $\begin{array}{l}-0.0380 \\
(-1.039)\end{array}$ & 0.071 & 0.16 \\
\hline \multicolumn{7}{|l|}{ Supplier Controls } \\
\hline Size & $\begin{array}{c}-0.427 * * * \\
(-14.63)\end{array}$ & $\begin{array}{c}-0.404 * * * \\
(-13.52)\end{array}$ & $\begin{array}{c}-0.429 * * * \\
(-15.16)\end{array}$ & $\begin{array}{c}-0.407 * * * \\
(-13.44)\end{array}$ & & \\
\hline$M T B$ & $\begin{array}{l}0.0175 \\
(1.031)\end{array}$ & $\begin{array}{l}0.0105 \\
(0.471)\end{array}$ & $\begin{array}{l}0.0154 \\
(0.892)\end{array}$ & $\begin{array}{l}0.0109 \\
(0.487)\end{array}$ & & \\
\hline Leverage & $\begin{array}{c}0.0609 * * * \\
(2.619)\end{array}$ & $\begin{array}{c}0.0897 * * * \\
(3.421)\end{array}$ & $\begin{array}{c}0.0627 * * * \\
(2.699)\end{array}$ & $\begin{array}{c}0.0911 * * * \\
(3.428)\end{array}$ & & \\
\hline $\mathrm{CFO}$ & $\begin{array}{c}-0.164 * * * \\
(-8.319)\end{array}$ & $\begin{array}{c}-0.214 * * * \\
(-8.438)\end{array}$ & $\begin{array}{c}-0.158 * * * \\
(-8.088)\end{array}$ & $\begin{array}{c}-0.211 * * * \\
(-8.157)\end{array}$ & & \\
\hline Capital Intensity & $\begin{array}{c}0.00548 \\
(0.125)\end{array}$ & $\begin{array}{l}0.0391 \\
(0.803)\end{array}$ & $\begin{array}{l}0.0108 \\
(0.248)\end{array}$ & $\begin{array}{l}0.0528 \\
(1.076)\end{array}$ & & \\
\hline \multicolumn{7}{|l|}{ Customer Controls } \\
\hline Cust_Analyst_Accuracy & $\begin{array}{c}-0.00292 \\
(-0.164)\end{array}$ & $\begin{array}{l}-0.0153 \\
(-0.817)\end{array}$ & $\begin{array}{c}0.00990 \\
(0.490)\end{array}$ & $\begin{array}{l}-0.0206 \\
(-1.095)\end{array}$ & & \\
\hline Cust_STD_ROA & $\begin{array}{c}0.0772 * * * \\
(4.181)\end{array}$ & $\begin{array}{c}0.0999 * * * \\
(4.912)\end{array}$ & $\begin{array}{c}0.0640 * * * \\
(3.957)\end{array}$ & $\begin{array}{c}0.105 * * * \\
(5.139)\end{array}$ & & \\
\hline Cust_Size & $\begin{array}{l}-0.00751 \\
(-0.328)\end{array}$ & $\begin{array}{l}0.0282 \\
(1.402)\end{array}$ & $\begin{array}{l}-0.0344 \\
(-1.474)\end{array}$ & $\begin{array}{l}0.0311 \\
(1.537)\end{array}$ & & \\
\hline Cust_MTB & $\begin{array}{l}0.0129 \\
(0.654)\end{array}$ & $\begin{array}{l}0.0242 \\
(1.271)\end{array}$ & $\begin{array}{l}0.0115 \\
(0.617)\end{array}$ & $\begin{array}{c}0.0330 * \\
(1.689)\end{array}$ & & \\
\hline
\end{tabular}

Continued 


\section{Table 6 continued}

\begin{tabular}{|c|c|c|c|c|c|c|}
\hline Dependent Variable: & Exp. Vol. & Exp. Vol. & Exp. Vol. & Exp. Vol. & & \\
\hline & $\begin{array}{c}\text { important } \\
\text { cust }\end{array}$ & $\begin{array}{c}\text { unimportant } \\
\text { cust }\end{array}$ & $\begin{array}{c}\text { important } \\
\text { cust }\end{array}$ & $\begin{array}{c}\text { unimportant } \\
\text { cust }\end{array}$ & $\begin{array}{l}\text { imp - } \\
\text { unimp }\end{array}$ & $\mathrm{P}\left(\chi^{2}\right)$ \\
\hline & Coeff & Coeff & Coeff & Coeff & & \\
\hline & T-Stat & T-Stat & T-Stat & T-Stat & & \\
\hline \multicolumn{7}{|l|}{ Macro } \\
\hline Recession & $\begin{array}{c}0.606 * * * \\
(14.27)\end{array}$ & $\begin{array}{c}0.562 * * * \\
(12.07)\end{array}$ & $\begin{array}{c}0.647 * * * \\
(14.67)\end{array}$ & $\begin{array}{c}0.575 * * * \\
(12.14)\end{array}$ & & \\
\hline Default_Spread & $\begin{array}{l}0.0267 \\
(1.622)\end{array}$ & $\begin{array}{c}0.0350^{* *} \\
(2.058)\end{array}$ & $\begin{array}{l}0.0265 \\
(1.433)\end{array}$ & $\begin{array}{c}0.0378 * * \\
(2.198)\end{array}$ & & \\
\hline Interest_Rate & $\begin{array}{c}-0.0259 * * \\
(-2.363)\end{array}$ & $\begin{array}{l}-0.0235 \\
(-1.637)\end{array}$ & $\begin{array}{c}-0.00837 \\
(-0.631)\end{array}$ & $\begin{array}{c}-0.00655 \\
(-0.441)\end{array}$ & & \\
\hline Observations & 4,467 & 4,298 & 4,467 & 4,298 & & \\
\hline R-squared & 0.412 & 0.413 & 0.402 & 0.403 & & \\
\hline Fixed Effects & Industry & Industry & Industry & Industry & & \\
\hline
\end{tabular}

Continued 
Table 6 continued

Panel B: The Effect of CIQ on Investment in WC

\begin{tabular}{|c|c|c|c|c|c|c|}
\hline Dependent Variable: & WC & WC & WC & WC & & \\
\hline & $\begin{array}{c}\text { important } \\
\text { cust }\end{array}$ & $\begin{array}{c}\text { unimportant } \\
\text { cust }\end{array}$ & $\begin{array}{c}\text { important } \\
\text { cust }\end{array}$ & $\begin{array}{c}\text { unimportan } \\
\text { t cust }\end{array}$ & $\begin{array}{l}\text { imp - } \\
\text { unimp }\end{array}$ & $\mathrm{P}\left(\chi^{2}\right)$ \\
\hline & Coeff & Coeff & Coeff & Coeff & & \\
\hline & T-Stat & T-Stat & T-Stat & T-Stat & & \\
\hline \multicolumn{7}{|l|}{ CIQ } \\
\hline$R E V$ & $\begin{array}{c}0.676^{* * *} \\
(2.924)\end{array}$ & $\begin{array}{c}0.821 * * \\
(2.523)\end{array}$ & & & -0.145 & 0.7 \\
\hline$M F$ & & & $\begin{array}{c}-0.150 \\
(-0.812)\end{array}$ & $\begin{array}{l}-0.0617 \\
(-0.203)\end{array}$ & -0.0883 & 0.73 \\
\hline \multicolumn{7}{|l|}{ Supplier Controls } \\
\hline Size & $\begin{array}{c}-0.611 * * * \\
(-4.929)\end{array}$ & $\begin{array}{c}-0.424 * * \\
(-2.141)\end{array}$ & $\begin{array}{c}-0.608 * * * \\
(-4.895)\end{array}$ & $\begin{array}{c}-0.417 * * \\
(-2.118)\end{array}$ & & \\
\hline$M T B$ & $\begin{array}{c}1.052 * * * \\
(5.273)\end{array}$ & $\begin{array}{c}1.725 * * * \\
(7.426)\end{array}$ & $\begin{array}{c}1.056^{* * *} \\
(5.349)\end{array}$ & $\begin{array}{c}1.729 * * * \\
(7.548)\end{array}$ & & \\
\hline Leverage & $\begin{array}{l}-0.341 * * \\
(-2.222)\end{array}$ & $\begin{array}{c}-1.176^{* * *} \\
(-6.025)\end{array}$ & $\begin{array}{c}-0.342 * * \\
(-2.219)\end{array}$ & $\begin{array}{c}-1.181 * * * \\
(-6.030)\end{array}$ & & \\
\hline$C F O$ & $\begin{array}{c}1.114 * * * \\
(7.861)\end{array}$ & $\begin{array}{c}1.166^{* * *} \\
(6.905)\end{array}$ & $\begin{array}{c}1.101^{* * *} \\
(7.843)\end{array}$ & $\begin{array}{c}1.150 * * * \\
(6.801)\end{array}$ & & \\
\hline Capital Intensity & $\begin{array}{c}-0.141 \\
(-0.789)\end{array}$ & $\begin{array}{c}0.107 \\
(0.534)\end{array}$ & $\begin{array}{c}-0.172 \\
(-0.988)\end{array}$ & $\begin{array}{l}0.0695 \\
(0.355)\end{array}$ & & \\
\hline \multicolumn{7}{|l|}{ Customer Controls } \\
\hline Cust_Analyst_Accuracy & $\begin{array}{c}0.165 \\
(1.591)\end{array}$ & $\begin{array}{l}0.247 * \\
(1.796)\end{array}$ & $\begin{array}{l}0.186^{*} \\
(1.840)\end{array}$ & $\begin{array}{l}0.269 * \\
(1.928)\end{array}$ & & \\
\hline Cust_STD_ROA & $\begin{array}{c}-0.161 \\
(-1.241)\end{array}$ & $\begin{array}{c}-0.261 \\
(-1.364)\end{array}$ & $\begin{array}{c}-0.190 \\
(-1.428)\end{array}$ & $\begin{array}{c}-0.291 \\
(-1.465)\end{array}$ & & \\
\hline Cust_Size & $\begin{array}{l}-0.184^{*} \\
(-1.935)\end{array}$ & $\begin{array}{c}-0.435^{* * *} \\
(-3.028)\end{array}$ & $\begin{array}{l}-0.187^{*} \\
(-1.840)\end{array}$ & $\begin{array}{c}-0.447 * * * \\
(-3.019)\end{array}$ & & \\
\hline Cust_MTB & $\begin{array}{l}0.0695 \\
(0.845)\end{array}$ & $\begin{array}{c}0.196 \\
(1.402)\end{array}$ & $\begin{array}{l}0.0354 \\
(0.380)\end{array}$ & $\begin{array}{c}0.157 \\
(1.039)\end{array}$ & & \\
\hline \multicolumn{7}{|l|}{ Macro } \\
\hline Recession & $\begin{array}{c}-1.930 * * * \\
(-6.010)\end{array}$ & $\begin{array}{c}-3.235 * * * \\
(-7.560)\end{array}$ & $\begin{array}{c}-1.963 * * * \\
(-6.168)\end{array}$ & $\begin{array}{c}-3.271 * * * \\
(-7.611)\end{array}$ & & \\
\hline Default_Spread & $\begin{array}{l}-0.0886 \\
(-0.733)\end{array}$ & $\begin{array}{c}-0.376^{* *} \\
(-2.408)\end{array}$ & $\begin{array}{l}-0.0948 \\
(-0.781)\end{array}$ & $\begin{array}{c}-0.385^{* *} \\
(-2.474)\end{array}$ & & \\
\hline Interest_Rate & $\begin{array}{c}-0.135 \\
(-1.155)\end{array}$ & $\begin{array}{c}-0.123 \\
(-0.723)\end{array}$ & $\begin{array}{c}-0.191 \\
(-1.633)\end{array}$ & $\begin{array}{c}-0.192 \\
(-1.123)\end{array}$ & & \\
\hline Observations & 4,467 & 4,298 & 4,467 & 4,298 & & \\
\hline R-squared & 0.05 & 0.073 & 0.06 & 0.058 & & \\
\hline Fixed Effects & Industry & Industry & Industry & Industry & & \\
\hline
\end{tabular}

Continued 
Table 6 continued

Panel C: The Effect of CIQ on Investment in WC

Assets

\begin{tabular}{|c|c|c|c|c|c|c|}
\hline Dependent Variable: & WC Assets & WC Assets & WC Assets & WC Assets & & \\
\hline & $\begin{array}{l}\text { important } \\
\text { cust }\end{array}$ & $\begin{array}{c}\text { unimportant } \\
\text { cust }\end{array}$ & $\begin{array}{l}\text { important } \\
\text { cust }\end{array}$ & $\begin{array}{c}\text { unimportant } \\
\text { cust }\end{array}$ & $\begin{array}{l}\text { imp - } \\
\text { unimp }\end{array}$ & $\mathrm{P}\left(\chi^{2}\right)$ \\
\hline & Coeff & Coeff & Coeff & Coeff & & \\
\hline & $T$-Stat & $T$-Stat & T-Stat & $T$-Stat & & \\
\hline \multicolumn{7}{|l|}{ CIQ } \\
\hline$R E V$ & $\begin{array}{c}0.589 * * \\
(2.268)\end{array}$ & $\begin{array}{c}0.728 * * * \\
(2.788)\end{array}$ & & & -0.139 & 0.33 \\
\hline$M F$ & & & $\begin{array}{c}-0.232 \\
(-0.733)\end{array}$ & $\begin{array}{l}-0.0882 \\
(-0.336)\end{array}$ & -0.1438 & 0.96 \\
\hline \multicolumn{7}{|l|}{ Supplier Controls } \\
\hline Size & $\begin{array}{c}-0.697 * * * \\
(-4.284)\end{array}$ & $\begin{array}{c}-0.541 * * * \\
(-3.404)\end{array}$ & $\begin{array}{c}-0.692 * * * \\
(-4.255)\end{array}$ & $\begin{array}{c}-0.539 * * * \\
(-3.396)\end{array}$ & & \\
\hline$M T B$ & $\begin{array}{c}1.095 * * * \\
(4.864)\end{array}$ & $\begin{array}{c}1.024 * * * \\
(4.841)\end{array}$ & $\begin{array}{c}1.101 * * * \\
(4.879)\end{array}$ & $\begin{array}{c}1.024 * * * \\
(4.817)\end{array}$ & & \\
\hline Leverage & $\begin{array}{l}-0.374 * * \\
(-2.236)\end{array}$ & $\begin{array}{l}-0.328 * \\
(-1.814)\end{array}$ & $\begin{array}{c}-0.376 * * \\
(-2.242)\end{array}$ & $\begin{array}{l}-0.328 * \\
(-1.788)\end{array}$ & & \\
\hline $\mathrm{CFO}$ & $\begin{array}{c}1.094 * * * \\
(5.471)\end{array}$ & $\begin{array}{c}1.154 * * * \\
(4.818)\end{array}$ & $\begin{array}{c}1.078 * * * \\
(5.429)\end{array}$ & $\begin{array}{c}1.146 * * * \\
(4.761)\end{array}$ & & \\
\hline Capital Intensity & $\begin{array}{c}-0.247 \\
(-0.957)\end{array}$ & $\begin{array}{l}-0.0289 \\
(-0.127)\end{array}$ & $\begin{array}{c}-0.263 \\
(-1.030)\end{array}$ & $\begin{array}{l}-0.0720 \\
(-0.316)\end{array}$ & & \\
\hline \multicolumn{7}{|l|}{ Customer Controls } \\
\hline Cust_Analyst_Accuracy & $\begin{array}{c}0.207 \\
(1.241)\end{array}$ & $\begin{array}{c}0.146 \\
(1.174)\end{array}$ & $\begin{array}{l}0.227 \\
(1.367)\end{array}$ & $\begin{array}{c}0.168 \\
(1.352)\end{array}$ & & \\
\hline Cust_STD_ROA & $\begin{array}{c}-0.142 \\
(-0.887)\end{array}$ & $\begin{array}{c}-0.202 \\
(-1.430)\end{array}$ & $\begin{array}{c}-0.178 \\
(-1.113)\end{array}$ & $\begin{array}{c}-0.224 \\
(-1.569)\end{array}$ & & \\
\hline Cust_Size & $\begin{array}{c}-0.161 \\
(-1.086)\end{array}$ & $\begin{array}{c}-0.186 \\
(-1.534)\end{array}$ & $\begin{array}{c}-0.166 \\
(-1.102)\end{array}$ & $\begin{array}{c}-0.180 \\
(-1.471)\end{array}$ & & \\
\hline Cust_MTB & $\begin{array}{c}0.116 \\
(0.794)\end{array}$ & $\begin{array}{l}0.0172 \\
(0.151)\end{array}$ & $\begin{array}{l}0.0813 \\
(0.554)\end{array}$ & $\begin{array}{l}-0.0139 \\
(-0.121)\end{array}$ & & \\
\hline \multicolumn{7}{|l|}{ Macro } \\
\hline Recession & $\begin{array}{c}-1.892 * * * \\
(-4.690)\end{array}$ & $\begin{array}{c}-2.020 * * * \\
(-5.534)\end{array}$ & $\begin{array}{c}-1.907 * * * \\
(-4.709)\end{array}$ & $\begin{array}{c}-2.067 * * * \\
(-5.655)\end{array}$ & & \\
\hline Default_Spread & $\begin{array}{l}-0.0781 \\
(-0.469)\end{array}$ & $\begin{array}{l}-0.0822 \\
(-0.549)\end{array}$ & $\begin{array}{l}-0.0863 \\
(-0.518)\end{array}$ & $\begin{array}{l}-0.0867 \\
(-0.577)\end{array}$ & & \\
\hline Interest_Rate & $\begin{array}{l}-0.288 * \\
(-1.853)\end{array}$ & $\begin{array}{c}0.0155 \\
(0.0974)\end{array}$ & $\begin{array}{l}-0.344 * * \\
(-2.270)\end{array}$ & $\begin{array}{l}-0.0329 \\
(-0.204)\end{array}$ & & \\
\hline Observations & 4,467 & 4,298 & 4,467 & 4,298 & & \\
\hline R-squared & 0.089 & 0.104 & 0.088 & 0.102 & & \\
\hline Fixed Effects & Industry & Industry & Industry & Industry & & \\
\hline
\end{tabular}

Continued 
Table 6 Continued

Panel D: Test of H2

Dependent Variable:

\begin{tabular}{cccc} 
WC & WC Assets & WC & WC Assets \\
\hline Coeff & Coeff & Coeff & Coeff \\
$T$-Stat & $T$-Stat & T-Stat & $T$-Stat \\
\hline
\end{tabular}

important cust

Rev

$0.606 * * \quad 0.603 *$

$M F$

(2.295)

(1.705)

Expected Volatility

$-0.33$

$-0.139$

$(-0.759)$

$(-0.322)$

$(-1.537)$

$-0.766 * * *$

$-0.379$

$-0.678^{*}$

Rev*Expected Volatility

$0.688^{*}$

$(-2.775)$

$(-1.390)$

$(-1.735)$

(1.956)

(2.932)

$M F^{*}$ Expected Volatility

$0.275 \quad 0.465$

(0.826) (0.957)

\begin{tabular}{|c|c|c|c|c|}
\hline \multicolumn{5}{|l|}{ unimportant cust } \\
\hline $\operatorname{Rev}$ & $\begin{array}{c}0.642 * * \\
(2.410)\end{array}$ & $\begin{array}{c}0.937 * * * \\
(2.630)\end{array}$ & & \\
\hline$M F$ & & & $\begin{array}{c}-0.107 \\
(-0.415)\end{array}$ & $\begin{array}{c}-0.115 \\
(-0.322)\end{array}$ \\
\hline Expected Volatility & $\begin{array}{l}-0.436 * \\
(-1.882)\end{array}$ & $\begin{array}{c}-1.214 * * * \\
(-4.350)\end{array}$ & $\begin{array}{c}-0.197 \\
(-0.656)\end{array}$ & $\begin{array}{c}-0.846^{* *} \\
(-2.200)\end{array}$ \\
\hline Rev*Expected Volatility & $\begin{array}{c}0.127 \\
(0.351)\end{array}$ & $\begin{array}{c}1.191 * * * \\
(2.611)\end{array}$ & & \\
\hline$M F^{*}$ Expected Volatility & & & $\begin{array}{c}-0.385 \\
(-1.332)\end{array}$ & $\begin{array}{c}-0.238 \\
(-0.592)\end{array}$ \\
\hline Supplier Controls & Yes & Yes & Yes & Yes \\
\hline Customer Controls & Yes & Yes & Yes & Yes \\
\hline Macro & Yes & Yes & Yes & Yes \\
\hline Difference in Interaction Term & 0.561 & 0.461 & 0.66 & 0.703 \\
\hline Chi-Squared & 1.26 & 0.42 & 2.17 & 1.19 \\
\hline P-Value & 0.2611 & 0.5191 & 0.1404 & 0.2763 \\
\hline Fixed Effects & Industry & Industry & Industry & Industry \\
\hline
\end{tabular}

Continued 
Table 6 Continued

Panel E: The Effect of CIQ on Expected Volatility Between Important and Unimportant Subsets

\begin{tabular}{|c|c|c|c|c|c|c|}
\hline Dependent Variable: & Exp. Vol. & Exp. Vol. & Exp. Vol. & Exp. Vol. & & \\
\hline & $\begin{array}{c}\text { important } \\
C \& S\end{array}$ & $\begin{array}{c}\text { unimportant } \\
C \& S\end{array}$ & $\begin{array}{c}\text { important } \\
C \& S\end{array}$ & $\begin{array}{c}\text { unimportant } \\
C \& S\end{array}$ & imp - unimp & $\mathrm{P}\left(\chi^{2}\right)$ \\
\hline & $\begin{array}{c}\text { Coeff } \\
\text { T-Stat } \\
\end{array}$ & $\begin{array}{l}\text { Coeff } \\
\text { T-Stat } \\
\end{array}$ & $\begin{array}{c}\text { Coeff } \\
\text { T-Stat } \\
\end{array}$ & $\begin{array}{c}\text { Coeff } \\
\text { T-Stat } \\
\end{array}$ & & \\
\hline REV & $\begin{array}{c}-0.194 * * * * \\
(-4.185)\end{array}$ & $\begin{array}{c}-0.294 * * * \\
(-6.440)\end{array}$ & & & 0.1 & 0.134 \\
\hline$M F$ & & & $\begin{array}{c}0.00616 \\
(0.183)\end{array}$ & $\begin{array}{l}0.0582 \\
(1.245)\end{array}$ & -0.052 & 0.473 \\
\hline \multicolumn{7}{|l|}{ Supplier Controls } \\
\hline Size & $\begin{array}{c}-0.382 * * * \\
(-11.42)\end{array}$ & $\begin{array}{c}-0.489 * * * \\
(-9.200)\end{array}$ & $\begin{array}{c}-0.383 * * * \\
(-19.02)\end{array}$ & $\begin{array}{c}-0.488 * * * \\
(-17.46)\end{array}$ & & \\
\hline$M T B$ & $\begin{array}{l}0.0313 \\
(1.389)\end{array}$ & $\begin{array}{l}0.00310 \\
(0.0900)\end{array}$ & $\begin{array}{c}0.0331^{*} \\
(1.925)\end{array}$ & $\begin{array}{l}-0.00131 \\
(-0.0579)\end{array}$ & & \\
\hline Leverage & $\begin{array}{l}0.0397 \\
(1.641)\end{array}$ & $\begin{array}{c}0.137 * * * * \\
(3.854)\end{array}$ & $\begin{array}{c}0.0400 * * \\
(2.287)\end{array}$ & $\begin{array}{c}0.140 * * * \\
(6.083)\end{array}$ & & \\
\hline$C F O$ & $\begin{array}{c}-0.180^{* * * *} \\
(-6.216)\end{array}$ & $\begin{array}{c}-0.212 * * * \\
(-6.268)\end{array}$ & $\begin{array}{c}-0.178 * * * * \\
(-9.318)\end{array}$ & $\begin{array}{c}-0.208^{* * * *} \\
(-10.55)\end{array}$ & & \\
\hline Capital Intensity & $\begin{array}{l}0.0484 \\
(1.305)\end{array}$ & $\begin{array}{l}0.0288 \\
(0.650)\end{array}$ & $\begin{array}{c}0.0546 * * \\
(2.266)\end{array}$ & $\begin{array}{l}0.0423 \\
(1.588)\end{array}$ & & \\
\hline \multicolumn{7}{|l|}{ Customer Controls } \\
\hline Cust_Analyst_Accuracy & $\begin{array}{c}0.00781 \\
(0.335)\end{array}$ & $\begin{array}{l}-0.0414 \\
(-0.899)\end{array}$ & $\begin{array}{c}0.00257 \\
(0.160)\end{array}$ & $\begin{array}{c}-0.0498^{* * *} \\
(-2.189)\end{array}$ & & \\
\hline Cust_STD_ROA & $\begin{array}{c}0.0651 * * \\
(2.547)\end{array}$ & $\begin{array}{c}0.0830 * * \\
(2.529)\end{array}$ & $\begin{array}{c}0.0731 * * * \\
(4.798)\end{array}$ & $\begin{array}{c}0.103 * * * \\
(4.198)\end{array}$ & & \\
\hline Cust_Size & $\begin{array}{l}0.0106 \\
(0.401)\end{array}$ & $\begin{array}{l}-0.0255 \\
(-0.732)\end{array}$ & $\begin{array}{l}0.0129 \\
(0.761)\end{array}$ & $\begin{array}{l}-0.0194 \\
(-0.738)\end{array}$ & & \\
\hline Cust_MTB & $\begin{array}{c}-0.00284 \\
(-0.117)\end{array}$ & $\begin{array}{l}0.0327 \\
(1.067)\end{array}$ & $\begin{array}{c}0.00504 \\
(0.332)\end{array}$ & $\begin{array}{c}0.0487 * * \\
(2.282)\end{array}$ & & \\
\hline \multicolumn{7}{|l|}{ Macro } \\
\hline Recession & $\begin{array}{c}0.606^{* * * *} \\
(14.27)\end{array}$ & $\begin{array}{c}0.562 * * * \\
(12.07)\end{array}$ & $\begin{array}{c}0.647 * * * \\
(14.67)\end{array}$ & $\begin{array}{c}0.575 * * * \\
(12.14)\end{array}$ & & \\
\hline Default_Spread & $\begin{array}{l}0.0267 \\
(1.622)\end{array}$ & $\begin{array}{c}0.0350^{* * *} \\
(2.058)\end{array}$ & $\begin{array}{l}0.0265 \\
(1.433)\end{array}$ & $\begin{array}{c}0.0378^{* * *} \\
(2.198)\end{array}$ & & \\
\hline Interest_Rate & $\begin{array}{c}-0.0259^{* *} \\
(-2.363)\end{array}$ & $\begin{array}{l}-0.0235 \\
(-1.637)\end{array}$ & $\begin{array}{c}-0.00837 \\
(-0.631)\end{array}$ & $\begin{array}{c}-0.00655 \\
(-0.441)\end{array}$ & & \\
\hline Observations & 2,317 & 2,229 & 2,321 & 2,236 & & \\
\hline R-squared & 0.486 & 0.369 & 0.478 & 0.356 & & \\
\hline Fixed Effects & Industry & Industry & Industry & Industry & & \\
\hline
\end{tabular}


Table 6 Continued

Panel F: The Effect of CIQ on Investment in WC Between Important and Unimportant Subsets

\begin{tabular}{|c|c|c|c|c|c|c|}
\hline Dependent Variable: & WC & WC & WC & WC & & \\
\hline & $\begin{array}{c}\text { important } \\
C \& S\end{array}$ & $\begin{array}{c}\text { unimportant } \\
C \& S\end{array}$ & $\begin{array}{c}\text { important } \\
C \& S\end{array}$ & $\begin{array}{c}\text { unimportant } \\
C \& S\end{array}$ & imp - unimp & $\mathrm{P}\left(\chi^{2}\right)$ \\
\hline & Coeff & Coeff & Coeff & Coeff & & \\
\hline & T-Stat & T-Stat & T-Stat & T-Stat & & \\
\hline \multirow[t]{2}{*}{$R E V$} & $0.695 * *$ & 0.469 & & & 0.226 & 0.67 \\
\hline & -1.993 & -1.078 & & & & \\
\hline$M F$ & & & $\begin{array}{c}-0.166 \\
(-0.475)\end{array}$ & $\begin{array}{l}-0.415 \\
(-1.033)\end{array}$ & 0.249 & 0.67 \\
\hline \multicolumn{7}{|l|}{ Supplier Controls } \\
\hline Size & $\begin{array}{c}-1.100 * * * \\
(-5.149)\end{array}$ & $\begin{array}{c}-0.622 * * \\
(-2.102)\end{array}$ & $\begin{array}{c}-1.095 * * * \\
(-5.020)\end{array}$ & $\begin{array}{c}-0.628 * * \\
(-2.127)\end{array}$ & & \\
\hline MTB & $\begin{array}{c}0.705 * * * \\
(2.760)\end{array}$ & $\begin{array}{c}1.278 * * * \\
(4.208)\end{array}$ & $\begin{array}{c}0.697 * * * \\
(2.735)\end{array}$ & $\begin{array}{c}1.287 * * * \\
(4.227)\end{array}$ & & \\
\hline Leverage & $\begin{array}{c}-0.176 \\
(-0.891)\end{array}$ & $\begin{array}{c}-0.184 \\
(-0.668)\end{array}$ & $\begin{array}{c}-0.173 \\
(-0.854)\end{array}$ & $\begin{array}{c}-0.188 \\
(-0.678)\end{array}$ & & \\
\hline CFO & $\begin{array}{c}1.087 * * * \\
(4.345)\end{array}$ & $\begin{array}{c}1.309 * * * \\
(4.181)\end{array}$ & $\begin{array}{c}1.079 * * * \\
(4.323)\end{array}$ & $\begin{array}{c}1.302 * * * \\
(4.182)\end{array}$ & & \\
\hline Capital Intensity & $\begin{array}{c}-0.689 * * \\
(-2.251)\end{array}$ & $\begin{array}{c}-0.254 \\
(-1.012)\end{array}$ & $\begin{array}{c}-0.707 * * \\
(-2.324)\end{array}$ & $\begin{array}{c}-0.273 \\
(-1.107)\end{array}$ & & \\
\hline \multicolumn{7}{|l|}{ Customer Controls } \\
\hline Cust_Analyst_Accuracy & $\begin{array}{l}0.0934 \\
(0.454)\end{array}$ & $\begin{array}{l}0.0580 \\
(0.343)\end{array}$ & $\begin{array}{l}0.120 \\
(0.583)\end{array}$ & $\begin{array}{l}0.0821 \\
(0.493)\end{array}$ & & \\
\hline Cust_STD_ROA & $\begin{array}{c}-0.476 * * * * \\
(-2.666)\end{array}$ & $\begin{array}{c}-0.315 \\
(-1.238)\end{array}$ & $\begin{array}{c}-0.509 * * * \\
(-2.809)\end{array}$ & $\begin{array}{c}-0.357 \\
(-1.408)\end{array}$ & & \\
\hline Cust_Size & $\begin{array}{l}-0.00679 \\
(-0.0437)\end{array}$ & $\begin{array}{l}0.0924 \\
(0.397)\end{array}$ & $\begin{array}{c}-0.0117 \\
(-0.0742)\end{array}$ & $\begin{array}{c}0.105 \\
(0.434)\end{array}$ & & \\
\hline Cust_MTB & $\begin{array}{c}0.154 \\
(1.085)\end{array}$ & $\begin{array}{l}-0.0389 \\
(-0.177)\end{array}$ & $\begin{array}{c}0.126 \\
(0.836)\end{array}$ & $\begin{array}{l}-0.0735 \\
(-0.320)\end{array}$ & & \\
\hline \multicolumn{7}{|l|}{ Macro } \\
\hline Recession & $\begin{array}{c}-1.363 * * \\
(-2.558)\end{array}$ & $\begin{array}{c}-2.536 * * * \\
(-4.788)\end{array}$ & $\begin{array}{c}-1.379 * * \\
(-2.588)\end{array}$ & $\begin{array}{c}-2.591 * * * \\
(-5.030)\end{array}$ & & \\
\hline Default_Spread & $\begin{array}{c}-0.102 \\
(-0.560)\end{array}$ & $\begin{array}{l}0.0760 \\
(0.314)\end{array}$ & $\begin{array}{c}-0.104 \\
(-0.572)\end{array}$ & $\begin{array}{l}0.0729 \\
(0.305)\end{array}$ & & \\
\hline Interest_Rate & $\begin{array}{c}-0.161 \\
(-1.031)\end{array}$ & $\begin{array}{c}0.0138 \\
(0.0604)\end{array}$ & $\begin{array}{c}-0.224 \\
(-1.437)\end{array}$ & $\begin{array}{l}-0.00742 \\
(-0.0319)\end{array}$ & & \\
\hline Observations & 2,317 & 2,229 & 2,317 & 2,229 & & \\
\hline R-squared & 0.062 & 0.078 & 0.060 & 0.078 & & \\
\hline Fixed Effects & Industry & Industry & Industry & Industry & & \\
\hline
\end{tabular}

Continued 
Table 6 Continued

Panel G: The Effect of CIQ on Investment in WC Assets Between Important and Unimportant Subsets

\begin{tabular}{|c|c|c|c|c|c|c|}
\hline Dependent Variable: & WC Assets & WC Assets & WC Assets & WC Assets & & \\
\hline & $\begin{array}{c}\text { important } \\
C \& S\end{array}$ & $\begin{array}{c}\text { unimportant } \\
C \& S\end{array}$ & $\begin{array}{c}\text { important } \\
C \& S \\
\end{array}$ & $\begin{array}{c}\text { unimportant } \\
C \& S \\
\end{array}$ & $\begin{array}{l}\text { imp - } \\
\text { unimp }\end{array}$ & $\mathrm{P}\left(\chi^{2}\right)$ \\
\hline & Coeff & Coeff & Coeff & Coeff & & \\
\hline & T-Stat & T-Stat & T-Stat & T-Stat & & \\
\hline \multicolumn{7}{|l|}{ CIQ } \\
\hline$R E V$ & $\begin{array}{l}1.047 * * \\
(2.481)\end{array}$ & $\begin{array}{c}0.894 \\
(1.647)\end{array}$ & & & 0.153 & 0.82 \\
\hline$M F$ & & & $\begin{array}{c}0.224 \\
(0.425)\end{array}$ & $\begin{array}{c}-0.267 \\
(-0.473)\end{array}$ & 0.491 & 0.54 \\
\hline \multicolumn{7}{|l|}{ Supplier Controls } \\
\hline Size & $\begin{array}{c}-0.994 * * * \\
(-3.682)\end{array}$ & $\begin{array}{c}-0.386 \\
(-1.151)\end{array}$ & $\begin{array}{c}-0.989 * * * \\
(-3.615)\end{array}$ & $\begin{array}{c}-0.390 \\
(-1.158)\end{array}$ & & \\
\hline$M T B$ & $\begin{array}{c}1.372 * * * \\
(4.908)\end{array}$ & $\begin{array}{c}1.976 * * * \\
(5.710)\end{array}$ & $\begin{array}{c}1.366 * * * \\
(4.962)\end{array}$ & $\begin{array}{c}1.990 * * * \\
(5.750)\end{array}$ & & \\
\hline Leverage & $\begin{array}{c}-0.712 * * * \\
(-2.975)\end{array}$ & $\begin{array}{c}-1.238 * * * \\
(-3.435)\end{array}$ & $\begin{array}{c}-0.721 * * * \\
(-2.966)\end{array}$ & $\begin{array}{c}-1.246^{* * * *} \\
(-3.447)\end{array}$ & & \\
\hline CFO & $\begin{array}{c}0.919 * * * \\
(3.197)\end{array}$ & $\begin{array}{c}1.527 * * * \\
(4.311)\end{array}$ & $\begin{array}{c}0.904 * * * \\
(3.133)\end{array}$ & $\begin{array}{c}1.516 * * * \\
(4.281)\end{array}$ & & \\
\hline Capital Intensity & $\begin{array}{c}-0.786 * * \\
(-2.163)\end{array}$ & $\begin{array}{c}0.124 \\
(0.365)\end{array}$ & $\begin{array}{c}-0.825 * * \\
(-2.297)\end{array}$ & $\begin{array}{l}0.0833 \\
(0.250)\end{array}$ & & \\
\hline \multicolumn{7}{|l|}{ Customer Controls } \\
\hline Cust_Analyst_Accuracy & $\begin{array}{c}0.279 \\
(1.155)\end{array}$ & $\begin{array}{c}0.0124 \\
(0.0584)\end{array}$ & $\begin{array}{c}0.293 \\
(1.185)\end{array}$ & $\begin{array}{l}0.0408 \\
(0.188)\end{array}$ & & \\
\hline Cust_STD_ROA & $\begin{array}{l}-0.524 * * \\
(-2.456)\end{array}$ & $\begin{array}{c}-0.573 \\
(-1.495)\end{array}$ & $\begin{array}{l}-0.559 * * \\
(-2.571)\end{array}$ & $\begin{array}{c}-0.637 \\
(-1.630)\end{array}$ & & \\
\hline Cust_Size & $\begin{array}{l}-0.406 * * \\
(-2.105)\end{array}$ & $\begin{array}{l}-0.0709 \\
(-0.239)\end{array}$ & $\begin{array}{l}-0.424 * * \\
(-2.183)\end{array}$ & $\begin{array}{l}-0.0830 \\
(-0.264)\end{array}$ & & \\
\hline Cust_MTB & $\begin{array}{c}0.271 \\
(1.386)\end{array}$ & $\begin{array}{c}0.382 \\
(1.307)\end{array}$ & $\begin{array}{c}0.229 \\
(1.101)\end{array}$ & $\begin{array}{c}0.331 \\
(1.070)\end{array}$ & & \\
\hline \multicolumn{7}{|l|}{ Macro } \\
\hline Recession & $\begin{array}{c}-3.348 * * * \\
(-5.351)\end{array}$ & $\begin{array}{c}-3.658 * * * \\
(-3.909)\end{array}$ & $\begin{array}{c}-3.359 * * * \\
(-5.335)\end{array}$ & $\begin{array}{c}-3.747 * * * \\
(-4.081)\end{array}$ & & \\
\hline Default_Spread & $\begin{array}{l}-0.0632 \\
(-0.244)\end{array}$ & $\begin{array}{c}-0.475 \\
(-1.523)\end{array}$ & $\begin{array}{l}-0.0723 \\
(-0.276)\end{array}$ & $\begin{array}{c}-0.486 \\
(-1.585)\end{array}$ & & \\
\hline Interest_Rate & $\begin{array}{c}-0.103 \\
(-0.546)\end{array}$ & $\begin{array}{l}0.0741 \\
(0.245)\end{array}$ & $\begin{array}{c}-0.199 \\
(-1.058)\end{array}$ & $\begin{array}{c}0.0239 \\
(0.0759)\end{array}$ & & \\
\hline Observations & 2,317 & 2,229 & 2,317 & 2,229 & & \\
\hline R-squared & 0.086 & 0.116 & 0.083 & 0.115 & & \\
\hline Fixed Effects & Industry & Industry & Industry & Industry & & \\
\hline
\end{tabular}

Continued 
Table 6 Continued

Panel H: Test of H2 Between Important and Unimportant Subsets

Dependent Variable:

WC

Coeff

WC Assets WC

WC Assets

T-Stat

Coeff

Coeff Coeff

\section{important $C \& S$}

Rev

$0.683 * \quad 1.340 * * *$

$M F$

(1.760) (2.955)

Expected Volatility

$-0.823 * * * \quad-1.240 * * *$

$-0.145$

0.240

$(-0.408)$

(0.446)

Rev*Expected Volatility

$(-3.008) \quad(-3.824)$

$-0.799 * *$

$-0.830 *$

0.467

$1.861 * * *$

$M F^{*}$ Expected Volatility

(0.969)

(3.278)

$(-2.420) \quad(-1.802)$

$0.275 \quad-0.0504$

$(0.185) \quad(-0.0907)$

\section{unimportant $C \& S$}

$\operatorname{Rev}$

$0.365 \quad 0.529$

(0.893) (1.062)

$M F$

Expected Volatility

$-0.381 * \quad-1.197 * * *$

$-0.0793$

$(-0.687) \quad(-0.151)$

Rev*Expected Volatility

$(-1.327) \quad(-3.545)$

$-0.0424 \quad-0.554$

0.202

$1.183^{*}$

(0.399)

(1.921)

$M F^{*}$ Expected Volatility

$(-1.061) \quad(-0.934)$

Supplier Controls

Customer Controls

Macro

Difference in Interaction Term

Chi-Squared

$P$-Value

Fixed Effects

$\begin{array}{llll}\text { Yes } & \text { Yes } & \text { Yes } & \text { Yes }\end{array}$

Yes Yes Yes Yes

Yes Yes $\quad$ Yes $\quad$ Yes

$\begin{array}{cccc}0.265 & 0.678 & 0.678 & 0.4686 \\ 0.15 & 0.44 & 0.68 & 0.33 \\ 0.697 & 0.507 & 0.411 & 0.565\end{array}$

Industry

Industry

Industry

Industry 


\section{Table 7: Restatements as a Proxy for CIQ}

This table shows results of tests using restatements as a proxy for CIQ. No_Error is an indicator variable that equals 1 if the customer firm restated any period in the three years ending in year $t$ and 0 otherwise. Panel A shows estimations of equation (2) in column 1 and equation (3) in columns 2 -5. Columns 3 and 5 include Expected_Volatility. Panel B shows estimations of equation (4). All continuous variables are winsorized at 1 and 99 percent and standardized to have zero mean and a standard deviation of $1 . *, * *$, and *** represent significance at the $.1, .05$, and .01 levels using a two-tailed test. Standard errors are clustered at the customer and supplier levels.

Panel A: The Effect of CIQ on Expected Volatility

\begin{tabular}{|c|c|c|c|c|c|}
\hline Dependent Variable: & Exp. Vol. & WC Acc & WC & WC Assets & WC Assets \\
\hline & Coeff & Coeff & Coeff & Coeff & $\begin{array}{l}\text { Coeff } \\
\text { T-Stat }\end{array}$ \\
\hline No_Error & $\begin{array}{l}0.0118 \\
(0.197)\end{array}$ & $\begin{array}{c}0.153 \\
(0.556)\end{array}$ & $\begin{array}{c}0.155 \\
(0.568)\end{array}$ & $\begin{array}{c}0.415 \\
(1.082)\end{array}$ & $\begin{array}{c}0.421 \\
(1.112)\end{array}$ \\
\hline Expected_Volatility & & & $\begin{array}{c}-0.186 \\
(-1.156)\end{array}$ & & $\begin{array}{l}-0.455^{*} \\
(-1.909)\end{array}$ \\
\hline \multicolumn{6}{|l|}{ Supplier Controls } \\
\hline Size & $\begin{array}{c}-0.443 * * * \\
(-19.47)\end{array}$ & $\begin{array}{c}-0.862 * * * * \\
(-6.987)\end{array}$ & $\begin{array}{c}-0.945 * * * \\
(-6.771)\end{array}$ & $\begin{array}{c}-0.670 * * * \\
(-3.493)\end{array}$ & $\begin{array}{c}-0.872 * * * \\
(-4.292)\end{array}$ \\
\hline$M T B$ & $\begin{array}{c}0.0365 * * * \\
(2.628)\end{array}$ & $\begin{array}{c}1.244 * * * \\
(6.929)\end{array}$ & $\begin{array}{c}1.251 * * * \\
(6.952)\end{array}$ & $\begin{array}{c}1.902 * * * \\
(8.835)\end{array}$ & $\begin{array}{c}1.919^{* * *} \\
(8.908)\end{array}$ \\
\hline Leverage & $\begin{array}{c}0.0760^{* * * *} \\
(3.871)\end{array}$ & $\begin{array}{c}-0.295 * * \\
(-2.024)\end{array}$ & $\begin{array}{l}-0.281^{*} \\
(-1.905)\end{array}$ & $\begin{array}{c}-1.126^{* * * *} \\
(-5.710)\end{array}$ & $\begin{array}{c}-1.092 * * * \\
(-5.387)\end{array}$ \\
\hline$C F O$ & $\begin{array}{c}-0.176 * * * \\
(-9.902)\end{array}$ & $\begin{array}{c}1.208^{* * * *} \\
(8.015)\end{array}$ & $\begin{array}{c}1.175 * * * \\
(7.487)\end{array}$ & $\begin{array}{c}1.409 * * * \\
(7.572)\end{array}$ & $\begin{array}{c}1.329 * * * \\
(6.763)\end{array}$ \\
\hline Capital Intensity & $\begin{array}{l}0.0309 \\
(1.469)\end{array}$ & $\begin{array}{c}-0.148 \\
(-0.974)\end{array}$ & $\begin{array}{c}-0.142 \\
(-0.937)\end{array}$ & $\begin{array}{l}-0.0671 \\
(-0.343)\end{array}$ & $\begin{array}{l}-0.0531 \\
(-0.270)\end{array}$ \\
\hline \multicolumn{6}{|l|}{ Customer Controls } \\
\hline Cust_STD_ROA & $\begin{array}{c}0.0820 * * * \\
(5.469)\end{array}$ & $\begin{array}{c}-0.301 * * \\
(-2.371)\end{array}$ & $\begin{array}{c}-0.286^{* *} \\
(-2.254)\end{array}$ & $\begin{array}{l}-0.335^{*} \\
(-1.809)\end{array}$ & $\begin{array}{c}-0.298 \\
(-1.592)\end{array}$ \\
\hline Cust_Size & $\begin{array}{l}-0.0120 \\
(-0.612)\end{array}$ & $\begin{array}{c}-0.120 \\
(-1.164)\end{array}$ & $\begin{array}{c}-0.122 \\
(-1.181)\end{array}$ & $\begin{array}{c}-0.343^{* *} \\
(-2.227)\end{array}$ & $\begin{array}{l}-0.348 * * \\
(-2.237)\end{array}$ \\
\hline Cust_MTB & $\begin{array}{c}0.0398^{* *} \\
(2.133)\end{array}$ & $\begin{array}{c}0.183 \\
(1.363)\end{array}$ & $\begin{array}{c}0.191 \\
(1.407)\end{array}$ & $\begin{array}{l}0.410 * * \\
(1.997)\end{array}$ & $\begin{array}{c}0.428 * * \\
(2.081)\end{array}$ \\
\hline
\end{tabular}

Continued 
Table 7 continued

\begin{tabular}{|c|c|c|c|c|c|}
\hline Dependent Variable: & $\begin{array}{l}\text { Exp. } \\
\text { Vol. }\end{array}$ & WC & WC & $\begin{array}{c}\text { WC } \\
\text { Assets }\end{array}$ & WC Assets \\
\hline & Coeff & Coeff & Coeff & Coeff & Coeff \\
\hline & T-Stat & T-Stat & T-Stat & T-Stat & T-Stat \\
\hline \multicolumn{6}{|l|}{ Macro } \\
\hline Recession & $\begin{array}{c}0.469 * * * \\
(12.11)\end{array}$ & $\begin{array}{c}-2.248 * * * \\
(-6.722)\end{array}$ & $\begin{array}{c}-2.161 * * * \\
(-6.266)\end{array}$ & $\begin{array}{c}-3.856 * * * \\
(-8.291)\end{array}$ & $\begin{array}{c}-3.642 * * * \\
(-7.797)\end{array}$ \\
\hline Default_Spread & $\begin{array}{c}0.0393 * * * \\
(2.976)\end{array}$ & $\begin{array}{c}-0.158 \\
(-1.318)\end{array}$ & $\begin{array}{c}-0.150 \\
(-1.263)\end{array}$ & $\begin{array}{c}-0.461 * * * \\
(-2.952)\end{array}$ & $\begin{array}{c}-0.443 * * * \\
(-2.850)\end{array}$ \\
\hline Interest_Rate & $\begin{array}{c}0.0974 * * * \\
(6.416)\end{array}$ & $\begin{array}{c}0.166 \\
(1.281)\end{array}$ & $\begin{array}{c}0.185 \\
(1.426)\end{array}$ & $\begin{array}{c}0.527 * * * \\
(2.611)\end{array}$ & $\begin{array}{c}0.571 * * * \\
(2.753)\end{array}$ \\
\hline Observations & 11,261 & 11,261 & 11,261 & 11,261 & 11,261 \\
\hline R-squared & 0.395 & 0.055 & 0.055 & 0.079 & 0.080 \\
\hline Fixed Effects & Industry & Industry & Industry & Industry & Industry \\
\hline
\end{tabular}




\section{Table 7 Continued}

Panel B: The Effect of CIQ on Investment - H2

Dependent Variable:

WC

Coeff

T-Stat

No_Error
Expected Volatility
No_Error*Expected Volatility

\section{Supplier Controls}

Size

MTB

Leverage

CFO

Capital Intensity

\section{Customer Controls}

Cust_STD_ROA

Cust_Size

Cust_MTB

\section{Macro}

Recession

Default_Spread

Interest_Rate

$\operatorname{Prob}($ Volatility $+C I Q *$ Volatility $=0)$

Observations

R-squared

Fixed Effects
0.139

(0.513)

$-0.473 *$

$(-1.755)$

0.320

(1.154)

$-0.943 * * *$

$(-6.734)$

$1.251 * * *$

(6.957)

$-0.281 *$

$(-1.913)$

$1.176 * * *$

(7.488)

$-0.142$

$(-0.935)$

$-0.284 * *$

$(-2.254)$

$-0.118$

$(-1.150)$

0.187

(1.379)

$-2.159 * * *$

(-6.260)

$-0.152$

(-1.274)

0.182

(1.403)

0.361

11,261

0.055

Industry
WC Assets

Coeff

T-Stat

0.383

(1.008)

$-1.143 * * *$

$(-3.790)$

$0.764 * *$

(2.335)

$-0.867 * * *$

(-4.270)

$1.920 * * *$

(8.916)

$-1.094 * * *$

$(-5.398)$

$1.330 * * *$

(6.751)

$-0.0524$

$(-0.268)$

$-0.294$

$(-1.589)$

$-0.339 * *$

$(-2.192)$

0.420 **

(2.041)

$-3.638 * * *$

(-7.796)

$-0.447 * * *$

(-2.870)

$0.565 * * *$

(2.718)

0.134

11,261

0.080

Industry 
Table 8: Sales Forecasting Accuracy as a Proxy for CIQ

This table shows results of tests using sales forecast accuracy as a proxy for CIQ. Rev_Accuracy is the average accuracy of annual sales forecasts for the three years preceding year $t$. Panel A shows estimations of equation (2) in column 1 and equation (3) in columns 2 -5. Columns 3 and 5 include Expected_Volatility. Panel B shows estimations of equation (4). All continuous variables are winsorized at 1 and 99 percent and standardized to have zero mean and a standard deviation of $1 . *$ * $^{* *}$, and *** represent significance at the $.1, .05$, and .01 levels using a two-tailed test. Standard errors are clustered at the customer and supplier levels.

Panel A: The Relationship Between Accuracy, Uncertainty, and Investment

\begin{tabular}{|c|c|c|c|c|c|}
\hline Dependent Variable: & Exp. Vol. & WC & WC & $\begin{array}{c}\text { WC } \\
\text { Assets }\end{array}$ & WC Assets \\
\hline & Coeff & Coeff & Coeff & Coeff & Coeff \\
\hline & $T$-Stat & T-Stat & T-Stat & T-Stat & T-Stat \\
\hline \multicolumn{6}{|l|}{ CIQ and Uncertainty } \\
\hline \multirow[t]{2}{*}{ Rev_Accuracy } & $-0.0288 * *$ & -0.0441 & -0.0401 & -0.150 & -0.130 \\
\hline & $(-2.077)$ & $(-0.459)$ & $(-0.416)$ & $(-1.177)$ & $(-0.997)$ \\
\hline \multirow[t]{2}{*}{ Expected Volatility } & & & 0.139 & & 0.692 \\
\hline & & & $(0.507)$ & & $(1.514)$ \\
\hline \multicolumn{6}{|l|}{ Supplier Controls } \\
\hline \multirow[t]{2}{*}{ Size } & $-0.491 * * *$ & $-0.680 * * *$ & $-0.611 * *$ & -0.416 & -0.0758 \\
\hline & $(-12.38)$ & $(-3.309)$ & $(-2.223)$ & $(-1.207)$ & $(-0.205)$ \\
\hline \multirow[t]{2}{*}{$M T B$} & 0.00227 & $1.210 * * *$ & $1.210 * * *$ & $1.554 * * *$ & $1.552 * * *$ \\
\hline & $(0.126)$ & $(3.856)$ & $(3.848)$ & $(4.201)$ & $(4.177)$ \\
\hline \multirow[t]{2}{*}{ Leverage } & $0.0875 * * *$ & -0.392 & -0.404 & $-1.264 * * *$ & $-1.325 * * *$ \\
\hline & $(3.523)$ & $(-1.547)$ & $(-1.594)$ & $(-3.931)$ & $(-4.007)$ \\
\hline \multirow[t]{2}{*}{ CFO } & $-0.207 * * *$ & $1.410 * * *$ & $1.439 * * *$ & $1.170 * * *$ & $1.314 * * *$ \\
\hline & $(-7.679)$ & $(6.204)$ & $(5.873)$ & $(4.251)$ & $(4.327)$ \\
\hline \multirow[t]{2}{*}{ Capital Intensity } & 0.0240 & 0.168 & 0.165 & 0.297 & 0.280 \\
\hline & $(0.791)$ & $(0.902)$ & $(0.891)$ & $(1.260)$ & $(1.225)$ \\
\hline \multicolumn{6}{|l|}{ Customer Controls } \\
\hline \multirow[t]{2}{*}{ Cust_Analyst_Accuracy } & $-0.0537 * * *$ & -0.169 & -0.162 & $-0.415^{* *}$ & $-0.378 * *$ \\
\hline & $(-3.314)$ & $(-1.643)$ & $(-1.649)$ & $(-2.361)$ & $(-2.101)$ \\
\hline \multirow[t]{2}{*}{ Cust_STD_ROA } & $0.0615 * * *$ & -0.103 & -0.112 & -0.127 & -0.170 \\
\hline & $(2.863)$ & $(-0.798)$ & $(-0.855)$ & $(-0.678)$ & $(-0.883)$ \\
\hline \multirow[t]{2}{*}{ Cust_Size } & -0.0163 & -0.173 & -0.170 & $-0.482 * *$ & $-0.470 * *$ \\
\hline & $(-0.647)$ & $(-0.985)$ & $(-0.982)$ & $(-2.032)$ & $(-2.023)$ \\
\hline \multirow[t]{2}{*}{ Cust_MTB } & $-0.0436 * *$ & 0.0703 & 0.0764 & $0.392 *$ & $0.422 * *$ \\
\hline & $(-2.353)$ & $(0.452)$ & $(0.487)$ & $(1.894)$ & $(2.069)$ \\
\hline
\end{tabular}

Continued 


\section{Table 8 Continued}

Panel A: The Relationship Between Accuracy, Uncertainty, and Investment

\begin{tabular}{|c|c|c|c|c|c|}
\hline Dependent Variable: & Exp. Vol. & WC & WC & $\begin{array}{c}\text { WC } \\
\text { Assets }\end{array}$ & $\begin{array}{c}\text { WC } \\
\text { Assets }\end{array}$ \\
\hline & Coeff & Coeff & Coeff & Coeff & Coeff \\
\hline & T-Stat & $T$-Stat & T-Stat & T-Stat & T-Stat \\
\hline \multicolumn{6}{|l|}{ Macro } \\
\hline \multirow[t]{2}{*}{ Recession } & $0.361 * * *$ & $-0.910 *$ & $-0.960 *$ & -1.044 & -1.294 \\
\hline & $(5.562)$ & $(-1.690)$ & $(-1.737)$ & $(-1.258)$ & $(-1.572)$ \\
\hline \multirow[t]{2}{*}{ Default_Spread } & $0.144 * * *$ & -0.205 & -0.225 & $-0.728 * *$ & $-0.827 * * *$ \\
\hline & $(5.625)$ & $(-0.898)$ & $(-1.029)$ & $(-2.335)$ & $(-2.705)$ \\
\hline \multirow[t]{2}{*}{ Interest_Rate } & $-0.0728 * * *$ & -0.101 & -0.0907 & -0.0277 & 0.0227 \\
\hline & $(-3.834)$ & $(-0.592)$ & $(-0.513)$ & $(-0.109)$ & $(0.0900)$ \\
\hline Observations & 3,380 & 3,380 & 3,380 & 3,380 & 3,380 \\
\hline R-squared & 0.475 & 0.055 & 0.055 & 0.064 & 0.067 \\
\hline Fixed Effects & Industry & Industry & Industry & Industry & Industry \\
\hline
\end{tabular}

\section{Continued}




\section{Table 8 Continued}

Panel B: Accuracy Mitigating the Effect of Uncertainty

Dependent Variable:

\begin{tabular}{|c|c|}
\hline WC & WC Assets \\
\hline Coeff & Coeff \\
\hline T-Stat & T-Stat \\
\hline-0.0380 & -0.131 \\
\hline$(-0.430)$ & $(-1.018)$ \\
\hline 0.143 & 0.699 \\
\hline$(0.519)$ & $(1.547)$ \\
\hline-0.0855 & -0.0600 \\
\hline$(-1.164)$ & $(-0.688)$ \\
\hline$-0.606 * *$ & -0.0624 \\
\hline$(-2.201)$ & $(-0.170)$ \\
\hline $1.210 * * *$ & $1.556 * * *$ \\
\hline$(3.847)$ & (4.157) \\
\hline-0.404 & $-1.321 * * *$ \\
\hline$(-1.589)$ & $(-3.997)$ \\
\hline $1.440 * * *$ & $1.323 * * *$ \\
\hline$(5.884)$ & $(4.317)$ \\
\hline 0.161 & 0.273 \\
\hline$(0.870)$ & (1.195) \\
\hline$-0.158 *$ & $-0.367 * *$ \\
\hline$(-1.758)$ & $(-2.178)$ \\
\hline-0.0933 & $-0.265 * * *$ \\
\hline$(-1.135)$ & $(-4.982)$ \\
\hline-0.111 & -0.172 \\
\hline$(-0.852)$ & $(-0.896)$ \\
\hline-0.171 & $-0.479 * *$ \\
\hline$(-0.991)$ & $(-2.069)$ \\
\hline 0.0748 & $0.416^{* *}$ \\
\hline$(0.479)$ & $(2.055)$ \\
\hline$-0.956^{*}$ & -1.299 \\
\hline$(-1.724)$ & $(-1.586)$ \\
\hline-0.223 & $-0.818 * * *$ \\
\hline$(-1.018)$ & $(-2.685)$ \\
\hline-0.0804 & 0.0451 \\
\hline$(-0.452)$ & $(0.180)$ \\
\hline 0.846 & 0.159 \\
\hline 3,380 & 3,380 \\
\hline 0.055 & 0.068 \\
\hline Industry & Industry \\
\hline
\end{tabular}

Prob( Volatility $+C I Q *$ Volatility $=0)$ 
Table 9: Earnings Forecasting Accuracy as a Proxy for CIQ

This table shows results of tests using sales forecast accuracy as a proxy for CIQ. Earn_accuracy is the average accuracy of annual earnings forecasts for the three years preceding year $t$. Panel A shows estimations of equation (2) in column 1 and equation (3) in columns 2 -5. Columns 3 and 5 include Expected_Volatility. Panel B shows estimations of equation (4). All continuous variables are winsorized at 1 and 99 percent and standardized to have zero mean and a standard deviation of 1 . *, **, and *** represent significance at the $.1, .05$, and .01 levels using a two-tailed test. Standard errors are clustered at the customer and supplier levels.

Panel A: The Relationship Between Accuracy, Uncertainty, and Investment

\begin{tabular}{|c|c|c|c|c|c|}
\hline Dependent Variable: & Exp. Vol. & WC & WC & WC Assets & WC Assets \\
\hline & Coeff & Coeff & Coeff & Coeff & Coeff \\
\hline & T-Stat & $T$-Stat & T-Stat & $T$-Stat & $T$-Stat \\
\hline \multicolumn{6}{|l|}{ CIQ and Uncertainty } \\
\hline \multirow[t]{2}{*}{ Earn_Accuracy } & $-0.0510 * *$ & -0.0880 & -0.102 & -0.212 & -0.240 \\
\hline & $(-2.012)$ & $(-0.658)$ & $(-0.779)$ & $(-1.355)$ & $(-1.541)$ \\
\hline \multirow[t]{2}{*}{ Expected_Volatility } & & & -0.281 & & $-0.557 *$ \\
\hline & & & $(-1.409)$ & & $(-1.699)$ \\
\hline \multicolumn{6}{|l|}{ Supplier Controls } \\
\hline \multirow[t]{2}{*}{ Size } & $-0.433 * * *$ & $-0.601 * * *$ & $-0.723 * * *$ & -0.337 & $-0.578 * *$ \\
\hline & $(-16.22)$ & $(-4.262)$ & $(-4.142)$ & $(-1.321)$ & $(-2.165)$ \\
\hline \multirow[t]{2}{*}{$M T B$} & 0.000203 & $1.059 * * *$ & $1.059 * * *$ & $1.666^{* * * *}$ & $1.666 * * *$ \\
\hline & $(0.0136)$ & $(4.373)$ & $(4.383)$ & $(5.701)$ & $(5.731)$ \\
\hline \multirow[t]{2}{*}{ Leverage } & $0.0765 * * *$ & $-0.431 * *$ & $-0.410 * *$ & $-1.302 * * *$ & $-1.259 * * *$ \\
\hline & $(3.077)$ & $(-2.349)$ & $(-2.226)$ & $(-5.685)$ & $(-5.295)$ \\
\hline \multirow[t]{2}{*}{$\mathrm{CFO}$} & $-0.171 * * *$ & $1.194 * * *$ & $1.146 * * *$ & $1.256 * * *$ & $1.160 * * *$ \\
\hline & $(-8.341)$ & $(7.423)$ & $(6.926)$ & $(6.526)$ & $(5.708)$ \\
\hline \multirow[t]{2}{*}{ Capital Intensity } & 0.0284 & -0.0101 & -0.00208 & 0.0906 & 0.106 \\
\hline & $(0.878)$ & $(-0.0469)$ & $(-0.00963)$ & $(0.388)$ & $(0.451)$ \\
\hline \multicolumn{6}{|l|}{ Customer Controls } \\
\hline \multirow[t]{2}{*}{ Cust_Analyst_Accuracy } & 0.0395 & $0.349 *$ & $0.360 * *$ & $0.563 * *$ & $0.585^{* *}$ \\
\hline & (1.111) & (1.918) & $(2.024)$ & $(2.184)$ & $(2.286)$ \\
\hline \multirow[t]{2}{*}{ Cust_STD_ROA } & $0.104 * * *$ & $-0.336 *$ & -0.307 & -0.473 & -0.415 \\
\hline & $(4.545)$ & $(-1.712)$ & $(-1.595)$ & $(-1.572)$ & $(-1.392)$ \\
\hline \multirow[t]{2}{*}{ Cust_Size } & -0.00250 & $-0.270 *$ & $-0.271 *$ & $-0.595 * * *$ & $-0.597 * * *$ \\
\hline & $(-0.0963)$ & $(-1.936)$ & $(-1.956)$ & $(-2.953)$ & $(-2.960)$ \\
\hline \multirow[t]{2}{*}{ Cust_MTB } & 0.0135 & -0.0118 & -0.00801 & 0.168 & 0.175 \\
\hline & $(0.494)$ & $(-0.0845)$ & $(-0.0579)$ & $(0.884)$ & $(0.936)$ \\
\hline
\end{tabular}

Continued 
Table 9 continued

Panel A: The Relationship Between Accuracy, Uncertainty, and Investment

\begin{tabular}{|c|c|c|c|c|c|}
\hline Dependent Variable: & Exp. Vol. & WC & WC & WC Assets & WC Assets \\
\hline & Coeff & Coeff & Coeff & Coeff & Coeff \\
\hline & T-Stat & T-Stat & T-Stat & T-Stat & $T$-Stat \\
\hline Macro & & & & & \\
\hline Recession & $0.620 * * *$ & $-1.950 * * *$ & $-1.775 * * *$ & $-3.159 * * *$ & $-2.814 * * *$ \\
\hline & $(11.83)$ & $(-5.099)$ & $(-4.509)$ & $(-6.047)$ & $(-5.468)$ \\
\hline Default_Spread & 0.0158 & 0.0271 & 0.0316 & -0.236 & -0.228 \\
\hline & $(0.845)$ & $(0.174)$ & $(0.203)$ & $(-1.233)$ & $(-1.186)$ \\
\hline Interest_Rate & -0.0154 & $-0.302 * *$ & $-0.306 * *$ & $-0.357 *$ & $-0.366^{*}$ \\
\hline & $(-1.170)$ & $(-2.067)$ & $(-2.085)$ & $(-1.706)$ & $(-1.743)$ \\
\hline Observations & 6,052 & 6,052 & 6,052 & 6,052 & 6,052 \\
\hline R-squared & 0.422 & 0.065 & 0.066 & 0.092 & 0.094 \\
\hline Fixed Effects & Industry & Industry & Industry & Industry & Industry \\
\hline
\end{tabular}

Continued 
Table 9 Continued

Panel B: Accuracy Mitigating the Effect of Uncertainty

Dependent Variable:

Coeff

A Assets

T-Stat T-Stat

\begin{tabular}{|c|c|c|}
\hline & & \\
\hline Earn_Accuracy & $\begin{array}{c}-0.136 \\
(-1.000)\end{array}$ & $\begin{array}{l}-0.295^{*} \\
(-1.862)\end{array}$ \\
\hline Expected Volatility & $\begin{array}{c}-0.262 \\
(-1.285)\end{array}$ & $\begin{array}{c}-0.559 * \\
(-1.689)\end{array}$ \\
\hline Earn_Accuracy*Expected Volatility & $\begin{array}{l}0.0628 \\
(0.500)\end{array}$ & $\begin{array}{l}0.0902 \\
(0.517)\end{array}$ \\
\hline \multicolumn{3}{|l|}{ Supplier Controls } \\
\hline Size & $\begin{array}{c}-0.721 * * * \\
(-3.953)\end{array}$ & $\begin{array}{c}-0.577 * * \\
(-2.093)\end{array}$ \\
\hline$M T B$ & $\begin{array}{c}1.094 * * * \\
(4.282)\end{array}$ & $\begin{array}{c}1.714 * * * \\
(5.644)\end{array}$ \\
\hline Leverage & $\begin{array}{c}-0.413 * * \\
(-2.215)\end{array}$ & $\begin{array}{c}-1.269 * * * \\
(-5.300)\end{array}$ \\
\hline$C F O$ & $\begin{array}{c}1.187 * * * \\
(6.863)\end{array}$ & $\begin{array}{c}1.183 * * * \\
(5.614)\end{array}$ \\
\hline Capital Intensity & $\begin{array}{l}0.00958 \\
(0.0531)\end{array}$ & $\begin{array}{l}0.0911 \\
(0.462)\end{array}$ \\
\hline \multicolumn{3}{|l|}{ Customer Controls } \\
\hline Cust_Analyst_Accuracy & $\begin{array}{c}0.298 * * \\
(2.027)\end{array}$ & $\begin{array}{c}0.490 * * \\
(2.521)\end{array}$ \\
\hline Cust_Analyst_Accuracy* Expected Volatility & $\begin{array}{l}0.0781 \\
(0.564)\end{array}$ & $\begin{array}{c}-0.186 \\
(-0.840)\end{array}$ \\
\hline Cust_STD_ROA & $\begin{array}{c}-0.237 \\
(-1.564)\end{array}$ & $\begin{array}{c}-0.362 \\
(-1.361)\end{array}$ \\
\hline Cust_Size & $\begin{array}{c}-0.262 * * \\
(-2.015)\end{array}$ & $\begin{array}{c}-0.577 * * * \\
(-3.020)\end{array}$ \\
\hline Cust_MTB & $\begin{array}{l}-0.0158 \\
(-0.122)\end{array}$ & $\begin{array}{c}0.164 \\
(0.937)\end{array}$ \\
\hline \multicolumn{3}{|l|}{ Macro } \\
\hline Recession & $\begin{array}{c}-1.790 * * * \\
(-4.510)\end{array}$ & $\begin{array}{c}-2.819 * * * \\
(-5.478)\end{array}$ \\
\hline Default_Spread & $\begin{array}{l}0.0204 \\
(0.132)\end{array}$ & $\begin{array}{c}-0.229 \\
(-1.204)\end{array}$ \\
\hline Interest_Rate & $\begin{array}{c}-0.304 * * \\
(-2.054)\end{array}$ & $\begin{array}{l}-0.360^{*} \\
(-1.726)\end{array}$ \\
\hline Prob( Volatility $+C I Q *$ Volatility $=0)$ & 0.252 & 0.325 \\
\hline Observations & 6,052 & 6,052 \\
\hline R-squared & 0.065 & 0.093 \\
\hline Fixed Effects & Industry & Industry \\
\hline
\end{tabular}


Table 10: Internal Control Weaknesses as a Proxy for CIQ

This table shows results of tests using internal control weaknesses as a proxy for CIQ. No_MW is an indicator variable that equals 1 if the customer firm did not disclose a material internal weakness in any period during the three years ending in year $t$ and 0 otherwise. Panel A shows estimations of equation (2) in column 1 and equation (3) in columns $2-5$. Columns 3 and 5 include Expected_Volatility. Panel B shows estimations of equation (4). All continuous variables are winsorized at 1 and 99 percent and standardized to have zero mean and a standard deviation of $1 . *, * *$, and *** represent significance at the $.1, .05$, and .01 levels using a two-tailed test. Standard errors are clustered at the customer and supplier levels.

Panel A: The Effect of CIQ on Expected Volatility

\begin{tabular}{|c|c|c|c|c|c|}
\hline Dependent Variable: & Exp. Vol. & WC Acc & WC & WC Assets & WC Assets \\
\hline & $\begin{array}{l}\text { Coeff } \\
\text { T-Stat }\end{array}$ & $\begin{array}{l}\text { Coeff } \\
\text { T-Stat }\end{array}$ & $\begin{array}{l}\text { Coeff } \\
\text { T-Stat }\end{array}$ & $\begin{array}{l}\text { Coeff } \\
\text { T-Stat }\end{array}$ & $\begin{array}{l}\text { Coeff } \\
\text { T-Stat }\end{array}$ \\
\hline No_MW & $\begin{array}{c}0.105 \\
(1.120)\end{array}$ & $\begin{array}{c}-0.404 \\
(-0.497)\end{array}$ & $\begin{array}{c}-0.408 \\
(-0.501)\end{array}$ & $\begin{array}{c}-0.784 \\
(-0.739)\end{array}$ & $\begin{array}{c}-0.787 \\
(-0.741)\end{array}$ \\
\hline Expected_Volatility & & & $\begin{array}{l}0.0337 \\
(0.172)\end{array}$ & & $\begin{array}{c}0.0202 \\
(0.0522)\end{array}$ \\
\hline \multicolumn{6}{|l|}{ Supplier Controls } \\
\hline Size & $\begin{array}{c}-0.464 * * * \\
(-16.33)\end{array}$ & $\begin{array}{c}-0.737 * * * \\
(-4.786)\end{array}$ & $\begin{array}{c}-0.721 * * * \\
(-4.098)\end{array}$ & $\begin{array}{c}-0.425 \\
(-1.564)\end{array}$ & $\begin{array}{c}-0.416 \\
(-1.576)\end{array}$ \\
\hline$M T B$ & $\begin{array}{c}0.00562 \\
(0.333)\end{array}$ & $\begin{array}{c}1.086 * * * \\
(4.045)\end{array}$ & $\begin{array}{c}1.086 * * * \\
(4.044)\end{array}$ & $\begin{array}{c}1.471 * * * \\
(5.095)\end{array}$ & $\begin{array}{c}1.471^{* * * *} \\
(5.108)\end{array}$ \\
\hline Leverage & $\begin{array}{c}0.111^{* * *} \\
(4.188)\end{array}$ & $\begin{array}{c}-0.317 \\
(-1.380)\end{array}$ & $\begin{array}{c}-0.321 \\
(-1.398)\end{array}$ & $\begin{array}{c}-1.353 * * * \\
(-4.974)\end{array}$ & $\begin{array}{c}-1.355^{* * *} \\
(-4.659)\end{array}$ \\
\hline$C F O$ & $\begin{array}{c}-0.195 * * * \\
(-8.466)\end{array}$ & $\begin{array}{c}1.183 * * * \\
(5.691)\end{array}$ & $\begin{array}{c}1.190^{* * *} \\
(5.452)\end{array}$ & $\begin{array}{c}1.217^{* * * *} \\
(5.599)\end{array}$ & $\begin{array}{c}1.221 * * * \\
(4.988)\end{array}$ \\
\hline Capital Intensity & $\begin{array}{l}-0.0125 \\
(-0.347)\end{array}$ & $\begin{array}{l}0.0252 \\
(0.106)\end{array}$ & $\begin{array}{l}0.0256 \\
(0.108)\end{array}$ & $\begin{array}{c}0.271 \\
(1.048)\end{array}$ & $\begin{array}{c}0.271 \\
(1.045)\end{array}$ \\
\hline \multicolumn{6}{|l|}{ Customer Controls } \\
\hline Cust_STD_ROA & $\begin{array}{c}0.0540 * * * \\
(3.064)\end{array}$ & $\begin{array}{c}0.117 \\
(1.005)\end{array}$ & $\begin{array}{c}0.115 \\
(0.983)\end{array}$ & $\begin{array}{l}-0.0685 \\
(-0.346)\end{array}$ & $\begin{array}{l}-0.0696 \\
(-0.343)\end{array}$ \\
\hline Cust_Size & $\begin{array}{l}-0.0250 \\
(-1.009)\end{array}$ & $\begin{array}{l}-0.0860 \\
(-0.600)\end{array}$ & $\begin{array}{l}-0.0852 \\
(-0.594)\end{array}$ & $\begin{array}{c}-0.332 \\
(-1.563)\end{array}$ & $\begin{array}{c}-0.332 \\
(-1.553)\end{array}$ \\
\hline Cust_MTB & $\begin{array}{c}-0.0496 * * * \\
(-3.787)\end{array}$ & $\begin{array}{l}0.0885 \\
(0.794)\end{array}$ & $\begin{array}{l}0.0902 \\
(0.798)\end{array}$ & $\begin{array}{l}0.300^{*} \\
(1.686)\end{array}$ & $\begin{array}{l}0.301 * \\
(1.691)\end{array}$ \\
\hline
\end{tabular}

Continued 
Table 10 continued

\begin{tabular}{|c|c|c|c|c|c|}
\hline Dependent Variable: & Exp. Vol. & WC Acc & WC & WC Assets & $\begin{array}{c}\text { WC } \\
\text { Assets }\end{array}$ \\
\hline & Coeff & Coeff & Coeff & Coeff & Coeff \\
\hline & T-Stat & $T$-Stat & T-Stat & $T$-Stat & T-Stat \\
\hline \multicolumn{6}{|l|}{ Macro } \\
\hline Recession & $\begin{array}{c}0.409 * * * \\
(8.412)\end{array}$ & $\begin{array}{c}-0.953 * * \\
(-2.002)\end{array}$ & $\begin{array}{c}-0.967 * * \\
(-1.998)\end{array}$ & $\begin{array}{c}-1.423 * * \\
(-2.348)\end{array}$ & $\begin{array}{c}-1.431 * * \\
(-2.447)\end{array}$ \\
\hline Default_Spread & $\begin{array}{c}0.136 * * * \\
(5.409)\end{array}$ & $\begin{array}{c}-0.349 * * \\
(-2.049)\end{array}$ & $\begin{array}{c}-0.354 * * \\
(-2.128)\end{array}$ & $\begin{array}{c}-0.865 * * * \\
(-3.600)\end{array}$ & $\begin{array}{c}-0.867 * * * \\
(-3.529)\end{array}$ \\
\hline Interest_Rate & $\begin{array}{c}-0.0583^{* * * *} \\
(-4.402)\end{array}$ & $\begin{array}{c}-0.136 \\
(-1.022)\end{array}$ & $\begin{array}{c}-0.134 \\
(-0.995)\end{array}$ & $\begin{array}{l}-0.0374 \\
(-0.185)\end{array}$ & $\begin{array}{l}-0.0363 \\
(-0.183)\end{array}$ \\
\hline Observations & 4,875 & 4,875 & 4,875 & 4,875 & 4,875 \\
\hline R-squared & 0.446 & 0.054 & 0.054 & 0.081 & 0.081 \\
\hline Fixed Effects & Industry & Industry & Industry & Industry & Industry \\
\hline
\end{tabular}


Table 10 Continued

Panel B: The Effect of CIQ on Investment

Dependent Variable:

WC Acc

Coeff

T-Stat

No_MW

Expected Volatility

No_MW*Expected Volatility

Supplier Controls

Size

MTB

Leverage

CFO

Capital Intensity

Customer Controls

Cust_STD_ROA

Cust_Size

Cust_MTB

Macro

Recession

Default_Spread

Interest_Rate

Prob( Volatility $+C I Q *$ Volatility $=0)$

Observations

R-squared

Fixed Effects
$-0.342$

$(-0.382)$

$-0.471$

$(-0.342)$

0.508

(0.368)

$-0.722 * * *$

$(-4.097)$

$1.084 * * *$

(4.028)

$-0.320$

$(-1.394)$

$1.191 * * *$

(5.452)

0.0248

(0.105)

0.118

(1.002)

$-0.0865$

$(-0.604)$

0.0912

(0.807)

$-0.966^{* *}$

$(-1.995)$

$-0.356^{* *}$

$(-2.139)$

$-0.133$

$(-0.988)$

0.846

4,875

0.054

Industry
WC Assets

Coeff

T-Stat

$-0.260$

$(-0.281)$

$-4.081 * * *$

(-3.646)

$4.138 * * *$

(3.720)

$-0.426$

$(-1.612)$

$1.465 * * *$

(5.074)

$-1.350 * * *$

(-4.640)

$1.229 * * *$

(5.008)

0.266

(1.027)

$-0.0539$

(-0.266)

$-0.341$

$(-1.608)$

0.310 *

(1.740)

$-1.422 * *$

$(-2.427)$

$-0.887 * * *$

(-3.602)

$-0.0309$

(-0.156)

0.885

4,875

0.083

Industry 
Table 11: Excluding Walmart

This table shows results of tests excluding all observations with Walmart as a customer. Panel A displays results of estimating equation (2) and panels $\mathrm{B}$ and $\mathrm{C}$ show estimations of equation (3) using WC and WC Assets as proxies for investment. Panel D displays results of $\mathrm{H} 2$. All continuous variables are winsorized at 1 and 99 percent and standardized to have zero mean and a standard deviation of $1 . *, * *$, and *** represent significance at the $.1, .05$, and .01 levels using a two-tailed test. Standard errors are clustered at the customer and supplier levels.

\begin{tabular}{lcc} 
Dependent Variable: & Exp. Vol. & Exp. Vol. \\
\hline & Coeff & Coeff \\
& $T$-Stat & T-Stat \\
\hline \hline CIQ & & \\
REV & $-0.247^{* * *}$ & \\
& $(-8.531)$ & \\
MF & & 0.00565 \\
& & $(0.147)$ \\
Supplier Controls & & \\
Size & $-0.407 * * *$ & $-0.408^{* * *}$ \\
& $(-16.93)$ & $(-16.82)$ \\
MTB & 0.0111 & 0.0111 \\
& $(0.692)$ & $(0.675)$ \\
Leverage & $0.0782^{* * *}$ & $0.0774^{* * *}$ \\
& $(3.546)$ & $(3.387)$ \\
CFO & $-0.190^{* * *}$ & $-0.187 * * *$ \\
& $(-9.536)$ & $(-9.269)$ \\
Capital Intensity & 0.0274 & 0.0411 \\
& $(1.027)$ & $(1.512)$ \\
Customer Controls & & \\
Cust_Analyst_Accuracy & 0.00393 & -0.00560 \\
& $(0.222)$ & $(-0.321)$ \\
Cust_STD_ROA & $0.0760^{* * * *}$ & $0.0852^{* * *}$ \\
Cust_Size & $(4.081)$ & $(4.606)$ \\
Cust_MTB & 0.0153 & 0.0120 \\
& $(0.802)$ & $(0.633)$ \\
& 0.00573 & 0.0153 \\
& $(0.290)$ & $(0.724)$ \\
& &
\end{tabular}

Continued 


\section{Table 11 continued}

\begin{tabular}{lcc} 
Dependent Variable: & Exp. Vol. & Exp. Vol. \\
\hline & Coeff & Coeff \\
& T-Stat & T-Stat \\
\hline \hline Macro & & \\
Recession & $0.618^{* * *}$ & $0.632^{* * *}$ \\
& $(13.90)$ & $(13.77)$ \\
Default_Spread & $0.0355^{* *}$ & $0.0328^{* *}$ \\
& $(2.196)$ & $(1.997)$ \\
Interest_Rate & $-0.0226^{*}$ & -0.00458 \\
& $(-1.910)$ & $(-0.406)$ \\
& & \\
Observations & 7,660 & 7,660 \\
R-squared & 0.399 & 0.386 \\
Fixed Effects & Industry & Industry \\
\hline
\end{tabular}

Continued 
Table 11 continued

Panel B: The Effect of CIQ on Investment Using WC

Dependent Variable:

\begin{tabular}{ccccc} 
WC & WC & WC & WC & Diff. \\
Coeff & Coeff & Coeff & Coeff & Diff. \\
T-Stat & $T$-Stat & T-Stat & T-Stat & $P\left(\chi^{2}\right)$ \\
\hline
\end{tabular}

CIQ and Uncertainty

REV

$0.825 * * * \quad 0.747 * * *$

$0.078^{*}$

$M F$

(4.246)

(4.027)

0.091

Expected_Volatility

$-0.314^{*}$

$\begin{array}{lll}-0.170 & -0.168 & -0.002\end{array}$

$(-1.781)$

$\begin{array}{lll}(-0.888) & (-0.891) & 0.827\end{array}$

Supplier Controls

Size

$\begin{array}{llll}-0.577 * * * & -0.704 * * * & -0.576 * * * & -0.731 * * *\end{array}$

$\begin{array}{llll}(-4.294) & (-4.567) \quad(-4.276) \quad(-4.717)\end{array}$

MTB

$1.171 * * *$

$1.174 * * * \quad 1.172 * * * \quad 1.177 * * *$

(6.272)

(6.270)

(6.343)

(6.335)

Leverage

$-0.364 * *$

$-0.340 * *$

$-0.358 * *$

$-0.329 * *$

$(-2.236)$

$(-2.070)$

$(-2.176)$

$(-1.984)$

CFO

$1.109 * * *$

$1.049 * * *$

$1.099 * * * \quad 1.029 * * *$

(7.348)

(6.709)

(7.345)

(6.612)

Capital Intensity

$-0.0273$

$-0.0187$

$-0.0732$

$-0.0577$

$(-0.163)$

$(-0.112)$

$(-0.434)$

$(-0.345)$

Customer Controls

Cust_Analyst_Accuracy

0.153

0.155

$0.190^{*}$

$0.188^{*}$

(1.422)

(1.454)

(1.788)

(1.793)

Cust_STD_ROA

$-0.165$

$-0.141$

$-0.201$

$-0.169$

(-1.201)

(-1.050)

$(-1.432)$

$(-1.241)$

Cust_Size

$-0.145$

$-0.141$

$-0.126$

$-0.122$

(-1.451)

$(-1.415)$

$(-1.213)$

$(-1.184)$

Cust_MTB

0.0592

0.0610

0.0252

0.0310

(0.678)

(0.707)

(0.253)

(0.319)

Macro

Recession

$-1.768 * * *$

$(-5.661)$

$-1.574 * * *$

$-1.817 * * *$

$-1.578 * * *$

Default_Spread

$-0.0959$

$(-5.059)$

$(-5.749)$

$(-5.051)$

$(-0.743)$

$-0.0847$

$-0.0830$

$-0.0706$

$-0.159$

$(-0.657)$

$(-0.635)$

$(-0.541)$

Interest_Rate

$(-1.272)$

-0.217 *

$-0.218 *$

7,660

(-1.318)

$(-1.740)$

$(-1.742)$

Observations

R-squared

0.065

7,660

7,660

7,660

Fixed Effects

Industry

0.066

0.063

0.064

Industry

Industry

Industry

Continued 
Table 11 Continued

Panel C: The Effect of CIQ on Investment Using WC Assets

Dependent Variable:

WC Assets WC Assets

WC Assets WC Assets Diff.

\begin{tabular}{|c|c|c|c|c|c|}
\hline & $\begin{array}{l}\text { Coeff } \\
T \text {-Stat } \\
\end{array}$ & $\begin{array}{l}\text { Coeff } \\
\text { T-Stat } \\
\end{array}$ & $\begin{array}{l}\text { Coeff } \\
T \text {-Stat } \\
\end{array}$ & $\begin{array}{l}\text { Coeff } \\
T \text {-Stat } \\
\end{array}$ & $\begin{array}{l}\text { Diff. } \\
P\left(\chi^{2}\right) \\
\end{array}$ \\
\hline \multicolumn{6}{|l|}{ CIQ and Uncertainty } \\
\hline REV & $\begin{array}{c}1.025^{* * * *} \\
(3.715)\end{array}$ & $\begin{array}{c}0.874 * * * \\
(3.248)\end{array}$ & & & $\begin{array}{c}0.151^{* *} \\
0.026\end{array}$ \\
\hline$M F$ & & & $\begin{array}{l}0.00505 \\
(0.0162)\end{array}$ & $\begin{array}{l}0.00892 \\
(0.0291)\end{array}$ & $\begin{array}{c}-0.00387 \\
0.826\end{array}$ \\
\hline Expected_Volatility & & $\begin{array}{l}-0.609^{* *} \\
(-2.182)\end{array}$ & & $\begin{array}{c}-0.685^{* *} \\
(-2.442)\end{array}$ & \\
\hline \multicolumn{6}{|l|}{ Supplier Controls } \\
\hline Size & $\begin{array}{l}-0.402 * \\
(-1.824)\end{array}$ & $\begin{array}{c}-0.650 * * * \\
(-2.959)\end{array}$ & $\begin{array}{l}-0.394 * \\
(-1.796)\end{array}$ & $\begin{array}{c}-0.674 * * * * \\
(-3.066)\end{array}$ & \\
\hline$M T B$ & $\begin{array}{c}1.871 * * * \\
(8.772)\end{array}$ & $\begin{array}{c}1.878 * * * * \\
(8.770)\end{array}$ & $\begin{array}{c}1.871^{* * * *} \\
(8.881)\end{array}$ & $\begin{array}{c}1.879 * * * \\
(8.860)\end{array}$ & \\
\hline Leverage & $\begin{array}{c}-1.212^{* * * *} \\
(-5.959)\end{array}$ & $\begin{array}{c}-1.165 * * * \\
(-5.585)\end{array}$ & $\begin{array}{c}-1.210 * * * \\
(-5.919)\end{array}$ & $\begin{array}{c}-1.157 * * * * \\
(-5.522)\end{array}$ & \\
\hline CFO & $\begin{array}{c}1.171^{* * * *} \\
(6.305)\end{array}$ & $\begin{array}{c}1.055 * * * \\
(5.259)\end{array}$ & $\begin{array}{c}1.158 * * * \\
(6.220)\end{array}$ & $\begin{array}{c}1.030 * * * \\
(5.116)\end{array}$ & \\
\hline Capital Intensity & $\begin{array}{c}0.216 \\
(1.090)\end{array}$ & $\begin{array}{c}0.233 \\
(1.176)\end{array}$ & $\begin{array}{c}0.159 \\
(0.800)\end{array}$ & $\begin{array}{c}0.187 \\
(0.945)\end{array}$ & \\
\hline \multicolumn{6}{|l|}{ Customer Controls } \\
\hline Cust_Analyst_Accuracy & $\begin{array}{c}0.234 \\
(1.633)\end{array}$ & $\begin{array}{c}0.237 \\
(1.647)\end{array}$ & $\begin{array}{l}0.273^{*} \\
(1.840)\end{array}$ & $\begin{array}{l}0.269^{*} \\
(1.818)\end{array}$ & \\
\hline Cust_STD_ROA & $\begin{array}{c}-0.253 \\
(-1.268)\end{array}$ & $\begin{array}{l}-0.206 \\
(-1.051)\end{array}$ & $\begin{array}{c}-0.290 \\
(-1.390)\end{array}$ & $\begin{array}{c}-0.231 \\
(-1.137)\end{array}$ & \\
\hline Cust_Size & $\begin{array}{c}-0.345^{* *} \\
(-2.336)\end{array}$ & $\begin{array}{c}-0.336^{* *} \\
(-2.323)\end{array}$ & $\begin{array}{c}-0.333^{* *} \\
(-2.284)\end{array}$ & $\begin{array}{c}-0.324 * * \\
(-2.279)\end{array}$ & \\
\hline Cust_MTB & $\begin{array}{c}0.171 \\
(1.146)\end{array}$ & $\begin{array}{c}0.174 \\
(1.216)\end{array}$ & $\begin{array}{c}0.131 \\
(0.814)\end{array}$ & $\begin{array}{c}0.142 \\
(0.924)\end{array}$ & \\
\hline \multicolumn{6}{|l|}{ Macro } \\
\hline Recession & $\begin{array}{c}-3.147^{* * * *} \\
(-6.831)\end{array}$ & $\begin{array}{c}-2.770^{* * * *} \\
(-6.049)\end{array}$ & $\begin{array}{c}-3.202^{* * *} \\
(-6.864)\end{array}$ & $\begin{array}{c}-2.770^{* * * *} \\
(-6.023)\end{array}$ & \\
\hline Default_Spread & $\begin{array}{l}-0.394 * * \\
(-2.340)\end{array}$ & $\begin{array}{c}-0.373^{* *} \\
(-2.212)\end{array}$ & $\begin{array}{c}-0.384 * * \\
(-2.248)\end{array}$ & $\begin{array}{c}-0.361 * * \\
(-2.116)\end{array}$ & \\
\hline Interest_Rate & $\begin{array}{c}-0.139 \\
(-0.747)\end{array}$ & $\begin{array}{c}-0.153 \\
(-0.819)\end{array}$ & $\begin{array}{c}-0.214 \\
(-1.139)\end{array}$ & $\begin{array}{c}-0.217 \\
(-1.150)\end{array}$ & \\
\hline Observations & 7,660 & 7,660 & 7,660 & 7,660 & \\
\hline $\mathrm{R}$-squared & 0.095 & 0.098 & 0.093 & 0.096 & \\
\hline Fixed Effects & Industry & Industry & Industry & Industry & \\
\hline
\end{tabular}

Continued 
Table 11 Continued

Panel D: Test of H1 using Revenue Forecasts

Dependent Variable:

WC Acc

WC Assets WC Acc WC Assets

Coeff Coeff Coeff Coeff

T-Stat

T-Stat

T-Stat

T-Stat

\section{CIQ and Uncertainty}

Rev

$0.656 * * * \quad 0.819 * * *$

$M F$

(3.095) (2.846)

(

Expected Volatility

Rev*Expected Volatility

$\begin{array}{ll}-0.390 * * & -0.988 * * * \\ (-2.084) & (-3.860)\end{array}$

$0.421 * \quad 1.436 * * *$

(1.778)

(3.660)

$M F^{*}$ Expected Volatility

\section{Supplier Controls}

Size

$M T B$

Leverage

CFO

Capital Intensity

Customer Controls

Cust_Analyst_Accuracy

Cust_Analyst_Accuracy*Volatility

$-0.677 * * *$

$(-4.356)$

$1.168 * * *$

(6.262)

$-0.336 * *$

$(-2.055)$

$1.067 * * *$

(6.781)

$-0.0333$

$(-0.200)$

$-0.564 * * *$

$(-2.631)$

$1.852 * * *$

$-0.170$

0.00445

$(-0.904) \quad(0.0145)$

$-0.348 \quad-0.786 * * *$

$(-1.632)$

(8.704)

$-1.166 * * *$

$-0.0264$

0.159

$(-0.120)$

(0.478)

$-0.725 * * * \quad-0.668 * * *$

$(-4.660) \quad(-3.048)$

$1.176 * * * \quad 1.880 * * *$

(6.360) (8.869)

$-0.325 * \quad-1.154 * * *$

$(-5.634)$

$(-1.963)$

$(-5.538)$

$1.094 * * *$

$1.036^{* * *}$

$1.033 * * *$

(5.430)

(6.654)

(5.085)

0.206

$-0.0664$

0.181

(1.050)

$(-0.395)$

(0.910)

$\begin{array}{llll}0.127 & 0.244 * & 0.159 & 0.261 *\end{array}$

$\begin{array}{llll}(1.281) & (1.788) & (1.614) & (1.823)\end{array}$

$\begin{array}{llll}0.172 & 0.0137 & 0.174 & 0.0369\end{array}$

$\begin{array}{llll}(1.390) & (0.0912) & (1.465) & (0.238)\end{array}$

Cust_STD_ROA

$-0.129$

$-0.189$

$-0.162$

$-0.226$

$(-0.984)$

$(-0.992)$

(-1.202)

(-1.112)

$-0.158$

$-0.356 * *$

$-0.134$

$-0.330 * *$

$(-1.612)$

$(-2.538)$

(-1.303)

$(-2.336)$

Cust_MTB

0.217

0.0250

0.144

(0.744)

(1.483)

(0.256)

(0.943) 
Table 11 Continued

\begin{tabular}{|c|c|c|c|c|}
\hline Dependent Variable: & WC Acc & $\begin{array}{c}\text { WC } \\
\text { Assets }\end{array}$ & WC Acc & $\begin{array}{c}\text { WC } \\
\text { Assets }\end{array}$ \\
\hline & Coeff & Coeff & Coeff & Coeff \\
\hline & T-Stat & T-Stat & T-Stat & T-Stat \\
\hline \multicolumn{5}{|l|}{ Macro } \\
\hline \multirow[t]{2}{*}{ Recession } & $-1.545 * * *$ & $-2.669 * * *$ & $-1.574 * * *$ & $-2.768 * * *$ \\
\hline & $(-4.959)$ & $(-5.765)$ & $(-5.034)$ & $(-6.008)$ \\
\hline \multirow[t]{2}{*}{ Default_Spread } & -0.117 & $-0.468 * * *$ & -0.0806 & $-0.361 * *$ \\
\hline & $(-0.943)$ & $(-2.822)$ & $(-0.616)$ & $(-2.116)$ \\
\hline \multirow[t]{2}{*}{ Interest_Rate } & -0.168 & -0.147 & $-0.223 *$ & -0.217 \\
\hline & $(-1.336)$ & $(-0.783)$ & $(-1.779)$ & $(-1.153)$ \\
\hline Prob $($ Volatility $+C I Q *$ Volatility $=0)$ & 0.81 & 0.37 & 0.07 & 0.067 \\
\hline Observations & 7,660 & 7,660 & 7,660 & 7,660 \\
\hline R-squared & 0.067 & 0.102 & 0.065 & 0.096 \\
\hline Fixed Effects & Industry & Industry & Industry & Industry \\
\hline
\end{tabular}


Figure 1: Theoretical Relationships

This figure demonstrates the simple relationship between CIQ and supplier investment. Line A shows the predicted negative relation between CIQ and uncertainty. Line B shows the relation between uncertainty and investment that has been demonstrated in prior literature and line $\mathrm{C}$ shows the resulting positive relationship between CIQ and investment that I expect.

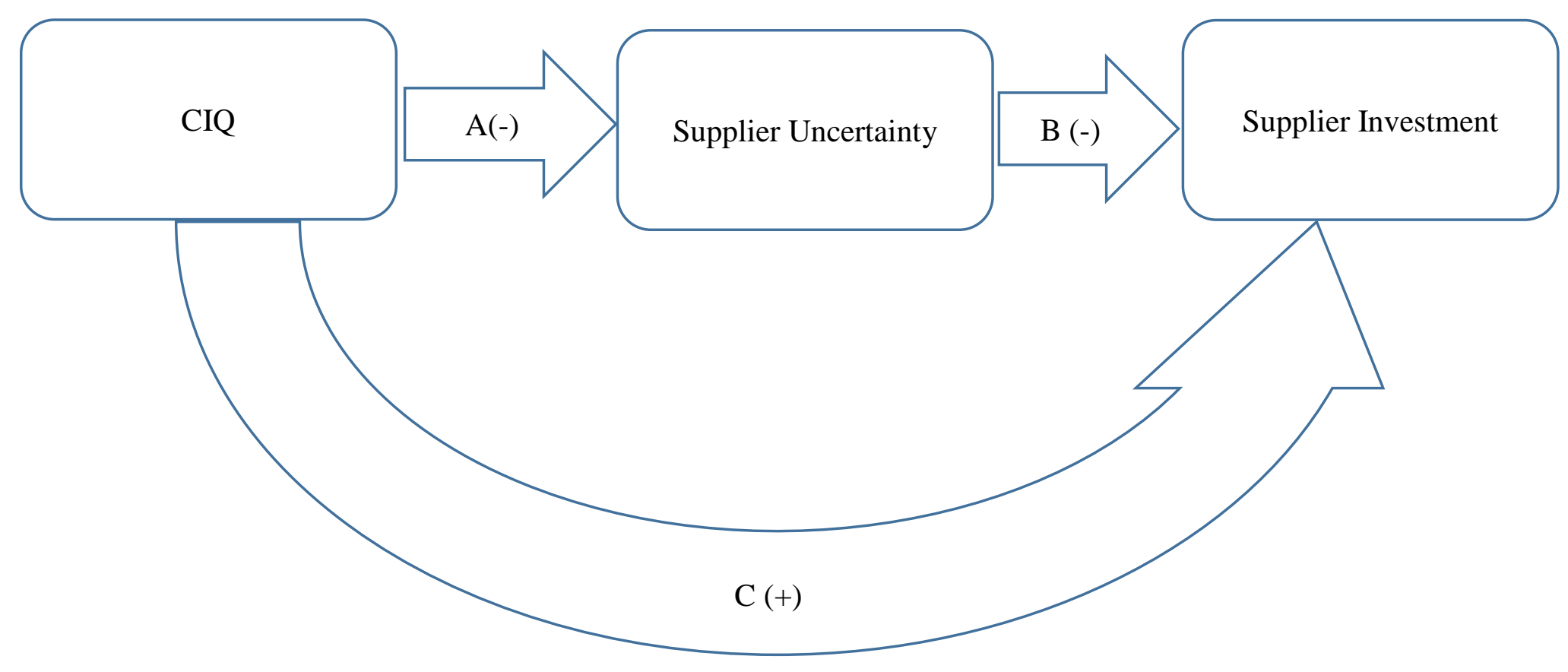


Appendix B: List of Variables

Variable Name
Information Quality
$R E V$

$M F$

Rev_Accuracy

Earn_accuracy

No_Error

Uncertainty

Expected Firm Volatility

\section{Investment}

$W C$

WC_Assets
Definition

An indicator variable for whether the customer has issued a management revenue forecast in the preceding three years.

An indicator variable for whether the customer has issued an annual earnings forecast in the preceding three years.

The absolute forecast error of a customer's annual sales forecasts measured during the three supplier's fiscal years before the year in which I examine investment. Forecast errors are measured as the actual revenue less forecasted revenue scaled by stock price three days before the guidance announcement. I multiply the measure by -1 for interpretation as accuracy.

The average accuracy of a customer's annual earnings forecasts measured during the three supplier's fiscal years before the year in which I examine investment. Accuracy is the absolute forecast error from I/B/E/S (abs(actual-value)) using the midpoint of ranged forecasts scaled by stock price three days before the forecast was issued. I multiply the final measure by -1 for interpretation.

An indicator variable for whether the customer did not have a non-fraudulent restatement for any period during the three years ending in year $t$.

The estimated total volatility from a GARCH $(1,1)$ model for the supplier firm's stock using returns available in year $t$ with at least 200 observations.

Working capital accruals in year $\mathrm{t}+1$ from Compustat scaled by total assets at the beginning of the year. Measured as $\Delta((\mathrm{rect}+\mathrm{invt}+\mathrm{aco})-(\mathrm{ap}+\mathrm{lco})) / \mathrm{at}$.

Working capital asset accruals in year $t+1$ from Compustat scaled by total assets at the beginning of the year. Measured as $\Delta($ rect + invt + aco $) /$ at. 
Capex

\section{Supplier Controls}

Size

$M T B$

Leverage

CFO

Capital Intensity

Customer Controls

Cust_Analyst_Accuracy

Cust_STD_ROA

Cust_Horizon

Cust_Size

PCT_Sales

Macro

Default_Spread

Interest_Rate

Recession
Capx from Compustat scaled by total assets (at) at the beginning of the year, measured in year $\mathrm{t}+1$.

The log of market value of equity as of the end of year t.

The market value of the firm scaled by book value of equity (seq) at the end of year $t$.

The ratio of debt to total assets at the end of year $t$.

Cash flows from operations scaled by total assets.

The net property plant and equipment (ppent) scaled by the total assets (at) at the beginning of year $t$.

The average accuracy of the customer firm's analysts measured over the same time period of Earn_accuracy. Using analyst sales forecasts when the test uses management sales forecasts and earnings forecasts when the test uses earnings.

The standard deviation of quarterly earnings (ibq/atq) over the same time period as Earn_accuracy.

The average of the log of the number of days before the earnings announcement that earnings guidance is released. i.e mean $(\log ($ announce_date - rdq $))$.

The log of market value of equity as of the end of year $t$.

The portion of the supplier's sales that go to the customer.

The default risk spread as of the middle of year $t+1$, measured as the yield spread between long-term Baa and Aaa rated securities from the St. Louis Federal Reserve Bank.

The nominal return on 1 year T-Bill as of the middle of year $\mathrm{t}+1$.

An indicator equal to 1 if any of the months in year $t+1$ are recognized as a recession by the NBER. 